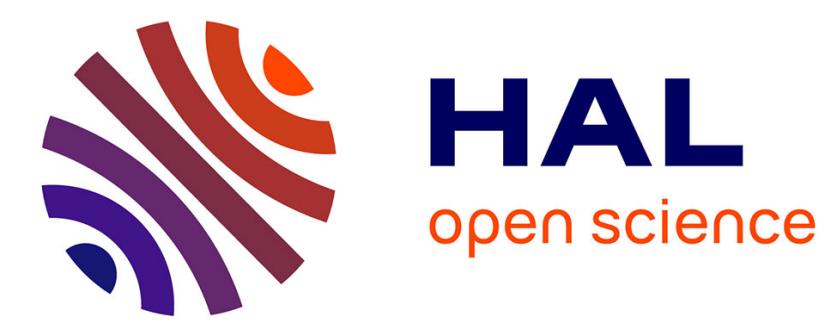

\title{
Formation age and metamorphic history of the Nuvvuagittuq Greenstone Belt
}

Jonathan O’Neil, Richard W. Carlson, Jean-Louis Paquette, Don Francis

\section{To cite this version:}

Jonathan O'Neil, Richard W. Carlson, Jean-Louis Paquette, Don Francis. Formation age and metamorphic history of the Nuvvuagittuq Greenstone Belt. Precambrian Research, 2012, 220-221, pp.23-44. 10.1016/j.precamres.2012.07.009 . hal-00793868

\section{HAL Id: hal-00793868 https://hal.science/hal-00793868}

Submitted on 18 Nov 2021

HAL is a multi-disciplinary open access archive for the deposit and dissemination of scientific research documents, whether they are published or not. The documents may come from teaching and research institutions in France or abroad, or from public or private research centers.
L'archive ouverte pluridisciplinaire HAL, est destinée au dépôt et à la diffusion de documents scientifiques de niveau recherche, publiés ou non, émanant des établissements d'enseignement et de recherche français ou étrangers, des laboratoires publics ou privés.

\section{다)(1) $(5$}

Distributed under a Creative Commons Attribution - NonCommerciall 4.0 International 


\title{
Formation age and metamorphic history of the Nuvvuagittuq Greenstone Belt
}

\author{
Jonathan O’Neil ${ }^{\mathrm{a}, \mathrm{b}, *}$, Richard W. Carlson ${ }^{\mathrm{a}}$, Jean-Louis Paquette $^{\mathrm{b}}$, Don Francis ${ }^{\mathrm{c}}$ \\ a Department of Terrestrial Magnetism, Carnegie Institution of Washington, 5241 Broad Branch Rd. NW, Washington, DC 20015, USA ${ }^{1}$ \\ ${ }^{\mathrm{b}}$ Laboratoire Magmas et Volcans, Université Blaise Pascal, 5 rue Kessler, Clermont-Ferrand 63000, France ${ }^{2}$ \\ ${ }^{\mathrm{c}}$ Earth and Planetary Sciences Department, McGill University, 3450 University St., Montreal, Quebec, Canada H3A $2 \mathrm{~A}^{3}$
}

\begin{abstract}
The Nuvvuagittuq Greenstone Belt (NGB) in Northern Quebec, Canada, is dominated by mafic and ultramafic rocks metamorphosed to at least upper amphibolite facies. Rare felsic intrusive rocks provide zircon ages of up to $\sim 3.8 \mathrm{Ga}$ (David et al., 2009; Cates and Mojzsis, 2007) establishing the minimum formation age of the NGB as Eoarchean. Primary U-rich minerals that may provide reliable formation ages for the dominant mafic lithology, called the Ujaraaluk unit, have yet to be found. Metamorphic zircons, rutiles and monazites are present in the unit and give variably discordant results with ${ }^{207} \mathrm{~Pb} /{ }^{206} \mathrm{~Pb}$ ages ranging from $2.8 \mathrm{Ga}$ to $2.5 \mathrm{Ga}$. The younger ages overlap $2686 \pm 4 \mathrm{Ma}$ zircon ages for intruding pegmatites (David et al., 2009) and Sm-Nd ages for garnet formation in the Ujaraaluk rocks suggesting this era as the time of peak metamorphism and metasomatism in the NGB, coeval with regional metamorphism of the Superior craton. Sm-Nd data for Ujaraaluk whole rocks scatter about a Sm/Nd vs. ${ }^{143} \mathrm{Nd} /{ }^{144} \mathrm{Nd}$ correlation (MSWD $=134$ ) whose slope would correspond to $3.6 \pm 0.2 \mathrm{Ga}$ if interpreted as an isochron. This "isochron" is seen to consist of a series of younger $~ 3.2-2.5 \mathrm{Ga}$ slopes for the different geochemical groups within the Ujaraaluk, emanating from a baseline distribution older than $4 \mathrm{Ga}$. The ${ }^{146} \mathrm{Sm}-{ }^{142} \mathrm{Nd}$ chronometer is less affected by metamorphism at $2.7 \mathrm{Ga}$ because of ${ }^{146} \mathrm{Sm}$ extinction prior to $\sim 4 \mathrm{Ga}$. Expansion of the ${ }^{142} \mathrm{Nd}$ dataset for the Ujaraaluk and associated ultramafic rocks continues to show a good correlation between $\mathrm{Sm} / \mathrm{Nd}$ ratio and ${ }^{142} \mathrm{Nd} /{ }^{144} \mathrm{Nd}$ that corresponds to an age of $4388^{+15}{ }_{-17}$ Ma. The dataset now includes samples with superchondritic $\mathrm{Sm} / \mathrm{Nd}$ ratios that extend the correlation to ${ }^{142} \mathrm{Nd}$ excesses of up to $8 \mathrm{ppm}$ compared to the terrestrial standard with a total range in ${ }^{142} \mathrm{Nd} /{ }^{144} \mathrm{Nd}$ of $26 \mathrm{ppm}$. The upper $\mathrm{Sm} / \mathrm{Nd}$ ratio end of the Ujaraaluk correlation is defined by rocks that are interpreted to be cumulates to compositionally related extrusive rocks indicating that this crystal fractionation had to occur while ${ }^{146} \mathrm{Sm}$ decay was active, i.e. well before $4 \mathrm{Ga}$. Intruding gabbros give ${ }^{143} \mathrm{Nd}$ and ${ }^{142} \mathrm{Nd}$ isochron ages of respectively $4115 \pm 100 \mathrm{Ma}$ and $4313^{+41}-69 \mathrm{Ma}$, also supporting an Hadean age for the gabbros and providing a minimum age for the intruded Ujaraaluk unit. 3.6 Ga tonalites surrounding the NGB, 3.8 Ga trondhjemitic intrusive veins, and a $2.7 \mathrm{Ga}$ pegmatite show a deficit in ${ }^{142} \mathrm{Nd}$ compared to the terrestrial standard. These felsic rocks plot to the low $\mathrm{Sm} / \mathrm{Nd}$ ratio side of the Ujaraaluk isochron and do not show a correlation between their $\mathrm{Sm} / \mathrm{Nd}$ and ${ }^{142} \mathrm{Nd} /{ }^{144} \mathrm{Nd}$ ratios, which can be explained if they are melts of ancient LREE-enriched mafic rocks, such as the Ujaraaluk, with the melting occurring after ${ }^{146} \mathrm{Sm}$ was extinct. A subset of least disturbed Ujaraaluk samples has coherent isotopic compositions for both short-lived and long-lived $\mathrm{Nd}$ isotopic systems giving ${ }^{143} \mathrm{Nd}$ and ${ }^{142} \mathrm{Nd}$ isochron ages overlapping within error of $4321 \pm 160 \mathrm{Ma}\left(\mathrm{MSWD}=6.3\right.$ ) and $4406^{+14}{ }_{-17} \mathrm{Ma}(\mathrm{MSWD}=1.0)$, respectively. This age represents our best age estimate for the Ujaraaluk unit. The NGB thus preserves over 1.6 billion years of early Earth history including an expanse of mafic crust formed in the Hadean.
\end{abstract}

\footnotetext{
* Corresponding author at: Department of Terrestrial Magnetism, Carnegie Institution of Washington, 5241 Broad Branch Rd. NW, Washington, DC 20015, USA. Tel.: +1 202478 8820; fax: +1 2024788821 .

E-mail address: joneil@dtm.ciw.edu (J. O’Neil).

1 Tel.: +1 202478 8820; fax: +1 2024788821 .

2 Tel.: +33 0473346711; fax: +330473346744

3 Tel.: +1 514398 6767; fax: +1 5143984680 .
}

\section{Introduction}

The first billion years of Earth history is poorly presented in the rock record with most early terrains being Eoarchean in age, leaving the Hadean Eon almost devoid of available samples. Until recently, the only available samples older than 4.1 billion years old (Ga) were detrital zircons from the Jack Hills conglomerate ( $4.4 \mathrm{Ga}$; Wilde et al., 2001$)$. Although these zircons provide invaluable information about the early Earth, their host rocks 
have been destroyed, leaving no direct samples of Earth's primordial crust. As a result, the nature of Earth's early crust and the processes responsible for its formation are largely conjecture. Other than these detrital zircons, rare occurrences of Eoarchean crust provide the only compositional constraints on the nature of Earth's early crust. These terrains include the Acasta Gneiss, Canada (4.03 Ga; Bowring and Williams, 1999), the Itsaq Gneiss Complex, Greenland (3.85-3.60 Ga; Nutman et al., 1996; Nutman and Friend, 2009), the Napier complex, Antarctica (3.95-3.8 Ga; Williams et al., 1986; Simon and Nigel, 2007), the Saglek-Hebron block, Labrador (3.78-3.73 Ga; Collerson, 1983; Schiotte et al., 1989), and the Anshan area, China (3.8 Ga; Song et al., 1996; Liu et al., 2008; Wu et al., 2008, 2009; Nutman et al., 2009). Earth's primitive crust is most likely to have been derived from the partial melting of the mantle to produce an early mafic crust. This is consistent with the Lu-Hf isotopic compositions of the Jack Hills zircons that suggest that their host rock was tonalitetrondhjemite-granodiorite (TTG) derived from the melting of a basaltic Hadean precursor (Blichert-Toft and Albarede, 2008; Kemp et al., 2010).

Investigation of Earth's primitive crust and the timing of its formation have largely focused on felsic rocks because they are the most likely host rocks for the zircons that provide robust geochronological constraints. These felsic rocks, however, cannot have been directly produced by melting of mantle peridotite. Instead, they likely were produced by melting of an older mafic precursor. Using zircon ages from felsic rocks to provide geochronological constraints on suites of mafic rocks requires a very accurate understanding of the geologic relationships between the different lithologies. Stratigraphic relationships between felsic and mafic units are rarely unequivocal in early Archean terrains that generally have been affected by multiple phases of intense deformation and metamorphism. This emphasizes the need to focus on the mafic component in Eoarchean/Hadean terrains in order to constrain the composition and the timing of formation of Earth's earliest crust. Unfortunately, obtaining accurate ages on old terrestrial mafic rocks is difficult due to their lack of zircon, the common recrystallization of their original igneous mineralogy during later metamorphic events, and their generally low concentrations of the incompatible-element-based radiometric systems used for dating. While long-lived isotopic systems such as ${ }^{147} \mathrm{Sm}-{ }^{143} \mathrm{Nd},{ }^{176} \mathrm{Lu}-{ }^{176} \mathrm{Hf}$ and ${ }^{187} \mathrm{Re}-{ }^{187} \mathrm{Os}$ are powerful tools to study the evolution of the crust-mantle system through time, Eoarchean/Hadean terrains usually have suffered extensive metamorphism and deformation that can affect these geochronometers through metamorphic/metasomatic redistribution of parent and/or daughter element any time after rock formation. On the other hand, the short-lived ${ }^{146} \mathrm{Sm}-{ }^{142} \mathrm{Nd}$ isotopic system (half life $=68 \mathrm{Ma}$; Kinoshita et al., 2012) is not as susceptible to partial resetting because ${ }^{146} \mathrm{Sm}$ became extinct prior to $\sim 4 \mathrm{Ga}$. Thus the ${ }^{146} \mathrm{Sm}-{ }^{142} \mathrm{Nd}$ system is an ideal tool to probe any potential Hadean terrain. ${ }^{142} \mathrm{Nd}$ deficits recently have been identified in the Nuvvuagittuq Greenstone Belt (NGB) mafic rocks (O'Neil et al., 2008) suggesting an age of nearly $4.3 \mathrm{Ga}$, which would make it the only known remnant of Hadean crust preserved on Earth. However, the oldest $\mathrm{U}-\mathrm{Pb}$ age obtained in zircon from rare intrusive felsic rocks in the NGB is $3817 \pm 16 \mathrm{Ma}$ (David et al., 2009). Nevertheless, the NGB offers a unique opportunity to constrain the composition of Earth's early crust and the processes responsible for the formation of crust in the Eoarchean/Hadean.

In this paper, we present an isotopic study combining both $\mathrm{Nd}$ long-lived and short-lived systems $\left({ }^{147} \mathrm{Sm}-{ }^{143} \mathrm{Nd}, T_{1 / 2}=106 \mathrm{Ga}\right.$ and ${ }^{146} \mathrm{Sm}-{ }^{142} \mathrm{Nd}, T_{1 / 2}=68 \mathrm{Ma}$ ) focusing on the mafic and ultramafic rocks of the NGB to put as many geochronological constraints as possible on the formation and evolution of the main lithology in the belt.

\section{Geologic setting}

The Nuvvuagittuq Greenstone Belt is located in Northern Quebec, Canada within the Hudson Bay terrane of the Northeastern Superior Province (Fig. 1). The Hudson Bay terrane is a TTGgreenstone terrain subdivided into different domains (Tikkerutuk, Bienville, Goudalie, La Grande, southern Douglas Harbour domains) and characterized by $\mathrm{Nd}$ model ages generally older than $3.0 \mathrm{Ga}$ (Boily et al., 2009). The old rocks of the terrane are intruded by a series of younger TTG $(\sim 2.7 \mathrm{Ga})$ with low initial ${ }^{143} \mathrm{Nd} /{ }^{144} \mathrm{Nd}$ suggesting recycling of older crust (Boily et al., 2009). The Hudson Bay terrane is interpreted to represent a cratonic nucleus of the Northeast Superior Province onto which the more juvenile rocks of the Rivière Arnaud terrane were juxtaposed. The NGB is a $\sim 10 \mathrm{~km}^{2}$ volcano-sedimentary sequence preserved on the East shore of Hudson Bay approximately $35 \mathrm{~km}$ south of the Inuit municipality of Inukjuak. The NGB is dominantly composed of mafic to ultramafic rocks with chemical sedimentary rocks and minor felsic components, all highly deformed and metamorphosed. The map pattern of the NGB (Fig. 1) is dominated by a large-scale North-closing synform plunging moderately to the South. The West limb of this open fold consists of a tight isoclinal South-closing synform with a steeply E-plunging fold axis. The NGB has been metamorphosed to at least upper amphibolite facies. Cates and Mojzsis (2009) proposed that the NGB experienced at least two significant metamorphic episodes around $3.6 \mathrm{Ga}$ and $2.7 \mathrm{Ga}$ based on overgrowth of zircons, with the Neoarchean event reaching $640^{\circ} \mathrm{C}$.

The NGB is dominated by mafic rocks. The most abundant lithology is a heterogeneous, but generally basaltic, group of rocks mainly composed of variable proportions of cummingtonite-biotite-plagioclase-garnet. Due to its important variation in mineralogy, we refer to this lithological unit as the Ujaraaluk unit (formerly called the faux-amphibolite; O'Neil et al., 2007, 2008) that comprises facies that include both cummingtonite-rich rocks and rocks that are dominated by a garnet-biotite paragenesis. Despite this wide range in mineralogical proportions, the different parageneses of the Ujaraaluk unit show a relatively small range of major element composition from basaltic to basaltic andesite (O'Neil et al., 2011a) reinforcing their grouping as a lithological unit. The Ujaraaluk unit can be subdivided into three distinct geochemical groups mainly based on $\mathrm{Al} / \mathrm{Ti}$ ratios and trace element profiles. These geochemical groups follow a chemical stratigraphy within the NGB with a high-Ti group that has relatively flat normalized incompatible trace element profiles at the base of the tight synform followed by a low-Ti group stratigraphically above. Chemical sediments lie at the transition between the high-Ti and the low-Ti Ujaraaluk groups. The low-Ti Ujaraaluk unit is further subdivided into two subgroups with distinct $\mathrm{Al} / \mathrm{Ti}$ ratios and trace element profiles referred as the depleted low-Ti group and the enriched low-Ti group based on their relative concentration of incompatible trace elements (O'Neil et al., 2011a). Rocks from the low-Ti Ujaraaluk unit directly above the chemical sediments have lower concentrations of incompatible trace elements and distinct U-shaped rare earth element (REE) profiles, whereas the rocks from the low-Ti Ujaraaluk at the top of the sequence have the most enriched REE profiles (O'Neil et al., 2011a). The Ujaraaluk unit as a whole is interpreted by O'Neil et al. (2011a) to represent hydrothermally altered mafic volcanic crust transitioning from rocks with tholeitic affinitities to rocks with boninitic and calcalkaline affinities deposited in a submarine volcanic environment. This is supported by the presence of deformed, but well-preserved pillows within the Ujaraaluk unit. The SW corner of the NGB contains massive aphanitic basaltic greenstones mainly composed of chlorite-epidote-quartz-plagioclase-actinolite (O'Neil et al., 2007). These greenstones can be divided into the same three compositional groups seen in the Ujaraaluk unit with the same 


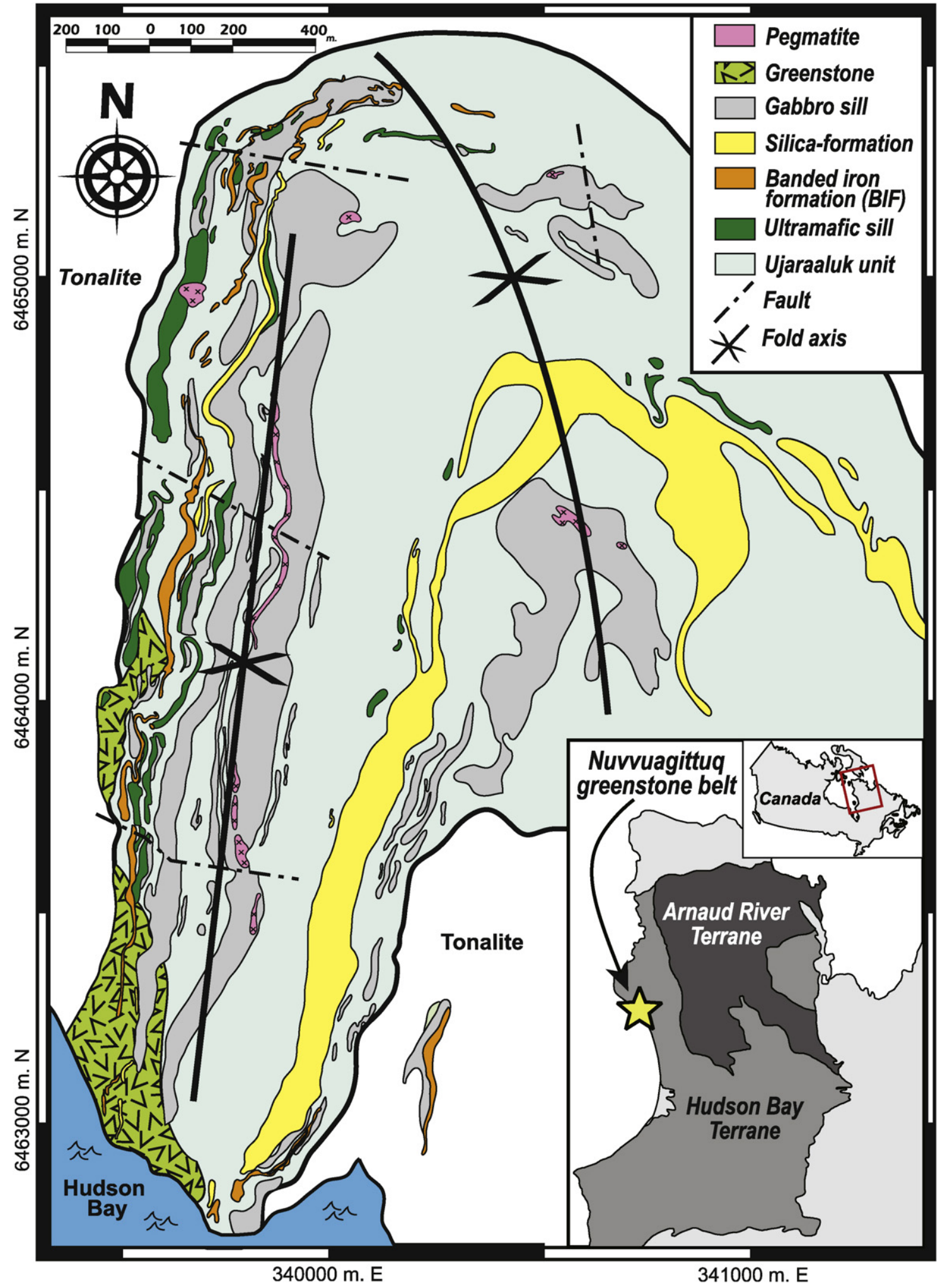

Fig. 1. Geologic map of the NGB. Coordinates are in UTM NAD 27.

geochemical characteristics [Fig. 1 Supplementary Data (SD1)] and following the same stratigraphy within the NGB. They are interpreted to be a lower grade, most likely retrograde, metamorphic equivalent to the Ujaraaluk unit. This interpretation is supported by the presence of these same greenstones to the SE of the NGB where they contain relicts of garnets completely chloriticized that display the same mineral texture observed in the garnet-rich Ujaraaluk rocks.

The Ujaraaluk unit includes ultramafic bodies that can be divided into the same three distinct geochemical groups following the same chemical stratigraphy as the Ujaraaluk mafic rocks (O'Neil et al., 2011a). These ultramafic bodies are interpreted to 
be ultramafic sills. They mainly consist of serpentine-rich interiors with amphibole-rich margins and locally exhibit amphibole-rich layers within the ultramafic interiors. The composition of the ultramafic rocks follow a well defined olivine-fractionation line and are interpreted to be ultramafic cumulates cogenetic with corresponding mafic Ujaraaluk groups sharing the same geochemical trends and characteristics (O'Neil et al., 2007, 2011a). The Ujaraaluk unit also is intruded by numerous highly deformed gabbroic sills. These mafic intrusions are composed of plagioclase and hornblende. They can reach $\sim 100 \mathrm{~m}$ in width and can sometimes be followed continuously over $1 \mathrm{~km}$.

Rare trondhjemitic rocks intruding the southern extremity of the NGB were dated at $3751 \pm 10 \mathrm{Ma}$ (Cates and Mojzsis, 2007), $3817 \pm 16 \mathrm{Ma}$ (David et al., 2009) and $3774 \pm 32 \mathrm{Ma}$ (Darling et al., 2012) indicating that the NGB is at least Eoarchean in age. The NGB is surrounded by a $3661 \pm 4$ Ga foliated tonalite (David et al., 2009) locally intruding the NGB to the West, itself sheathed by younger $(2750 \pm 16 \mathrm{Ma})$ heterogeneous tonalities from the Tikkerutuk domain (Simard et al., 2003). The NGB also is intruded by Neoarchean pegmatitic sheets that provide zircon dates of $2686 \pm 4 \mathrm{Ma}$ (David et al., 2009). David et al. (2009) obtained U-Pb ages in zircons from a gabbro associated with the tonalite in the center of the synform and from a plagioclase-quartz-biotite schist. These samples yielded ages of $2693 \pm 3 \mathrm{Ma}$ and $3366 \pm 2.5 \mathrm{Ma}$ respectively, interpreted to be metamorphic ages.

Zircons from what is interpreted to be a conglomeratic unit in the NGB yield ${ }^{207} \mathrm{~Pb} /{ }^{206} \mathrm{~Pb}$ ages ranging from $3770 \mathrm{Ma}$ to $3258 \mathrm{Ma}$ (David et al., 2009). These zircons lie along a discordia with an upper intercept of $3787 \pm 25 \mathrm{Ma}$. These conglomeratic units, however, are found only within high-strain zones and always within less than $100 \mathrm{~m}$ of the southern NGB-tonalite boundary making their relationship with the adjacent lithologies and exact origin equivocal.

Controversy about the age of the NGB emerged after O'Neil et al. (2008) showed that the Ujaraaluk unit had a deficit in ${ }^{142} \mathrm{Nd}$ relative to the terrestrial standard $\mathrm{Nd}$, Unlike most occurrences of variable ${ }^{142} \mathrm{Nd}$ in early Earth rocks, the NGB rocks show a correlation between ${ }^{142} \mathrm{Nd} /{ }^{144} \mathrm{Nd}$ and ${ }^{147} \mathrm{Sm} /{ }^{144} \mathrm{Nd}$ that, if interpreted as an isochron yields an age of $4.37 \mathrm{Ga}$ [an age of $4.28 \mathrm{Ga}$ was reported by O'Neil et al. (2008), but all ${ }^{146} \mathrm{Sm}-{ }^{142} \mathrm{Nd}$ ages reported in this paper are calculated using the newly determined ${ }^{146} \mathrm{Sm}$ half life of $68 \mathrm{Ma}$ and recalculated Solar system initial ${ }^{146} \mathrm{Sm} /{ }^{144} \mathrm{Sm}=0.0094$ (Kinoshita et al., 2012)]. An Hadean age for the Ujaraaluk unit is supported by a ${ }^{143} \mathrm{Nd} /{ }^{144} \mathrm{Nd}$ vs. ${ }^{147} \mathrm{Sm} /{ }^{144} \mathrm{Nd}$ isochron for intruding gabbros that provides an age of over $4.1 \mathrm{Ga}$ for these intrusive units. While the surrounding and intruding felsic lithologies of the NGB suggest an Eoarchean age, the dominant mafic lithologies yield an Hadean isotopic signature suggesting that the NGB could represent the oldest preserved crust on Earth.

\section{Analytical procedures}

Weathered surfaces and quartz veins were removed from rock samples prior to crushing. Weathering-free samples were crushed in a steel jaw crusher and then ground to powder in an alumina shatter box. Some samples contain coarse-grained garnet and therefore, to obtain representative whole rock powders, large size samples $(15-20 \mathrm{~cm})$ were crushed.

Whole rock samples were digested using a flux-fusion technique. Between 250 and $350 \mathrm{mg}$ of powdered sample was fused in graphite crucibles using $\sim 0.8 \mathrm{~g}$ of a mixture of $67 \%$ lithium tetraborate- $33 \%$ lithium metaborate and $\sim 0.02 \mathrm{~g}$ of lithium bromide for $20 \mathrm{~min}$ at $1050^{\circ} \mathrm{C}$. The molten beads were poured into a Teflon beaker containing $40 \mathrm{ml}$ of $2 \mathrm{M} \mathrm{NHO}_{3}$ and stirred for 20 min until the glass was completely dissolved. The dissolved samples were filtered to remove flakes of graphite from the crucibles.
Aliquots of this solution corresponding to $10 \%$ of the dissolved sample were spiked with enriched ${ }^{150} \mathrm{Nd}-{ }^{149} \mathrm{Sm}$ tracers to measure the Sm and Nd concentrations by isotope dilution. The remaining $90 \%$ of the dissolved sample was not spiked and was used for $\mathrm{Nd}$ isotope measurements $\left({ }^{142} \mathrm{Nd}\right.$ and $\left.{ }^{143} \mathrm{Nd}\right)$. From both spiked and unspiked aliquots of the dissolution solution, the REE were precipitated by raising the $\mathrm{pH}$ of the $\mathrm{HNO}_{3}$ solution to between 5.5 and 6 by the addition of $\mathrm{NH}_{4} \mathrm{OH}$. An Fe solution prepared from $99.9 \%$ anhydrous Aldrich $\mathrm{FeCl}_{2}$ was previously added to both spiked and unspiked dissolved fractions to facilitate the precipitation. The precipitates were re-dissolved in $2.5 \mathrm{M} \mathrm{HCl}$ and loaded onto primary columns $(1 \mathrm{~cm} \times 20 \mathrm{~cm})$ filled with $200-400$ mesh AG50W-X8 cation-exchange resin for the REE extraction. Sm and Nd were extracted from this REE fraction using methylactic acid as described in Boyet and Carlson (2005). Both Sm and Nd were extracted from the spiked aliquot with one pass through the methylactic acid columns whereas only the Nd was extracted on the unspiked aliquots but with three passes through the methylactic acid columns in order to remove as much $\mathrm{Ce}$ and $\mathrm{Sm}$ as possible. Six Ujaraaluk samples also were measured for their unspiked $\mathrm{Sm}$ isotopic compositions to check for possible neutron irradiation or meteoritic components in these rocks. All six samples showed $\mathrm{Sm}$ isotopic compositions within error of the terrestrial standard (Table SD1). For the samples from barrel B369 and higher (see Table SD2), the Nd fractions for both spiked and unspiked aliquots obtained after methylactic acid columns were then purified by passing the samples through columns filled with $300 \mathrm{mg}$ of Eichrom Ln Resin 50-100 $\mu \mathrm{m}$. No variation within error of the ${ }^{142} \mathrm{Nd} /{ }^{144} \mathrm{Nd}$ ratios has been observed for duplicate samples (Table SD3) that have been purified with Eichrom Ln Resin.

Garnet separates were obtained after sieving of the crushed rock samples to collect a grain fraction between $120 \mu \mathrm{m}$ and $75 \mu \mathrm{m}$. The grains were washed and garnets were separated from the other grains by magnetic separation. The cleanest garnet grains were then handpicked under a binocular microscope to avoid composite grains. This cleaner garnet fraction was leached following Pollington and Baxter (2010) to remove inclusions and then powdered using an agate mortar/pestle. Garnet samples ( $\sim 65 \mathrm{mg}$ ) were digested in Parr bombs under pressure with a $\mathrm{HF}-\mathrm{HNO}_{3}$ mixture in Teflon containers.

Whole rock samples for Lu-Hf analysis were fused and precipitated using the same procedure as for the Sm-Nd. Samples were spiked with enriched tracers of ${ }^{176} \mathrm{Lu}$ and ${ }^{178} \mathrm{Hf}$. The spike solution was added in the Teflon beaker with $40 \mathrm{ml}$ of $2 \mathrm{M} \mathrm{NHO}_{3}$ before pouring of the fused bead to assure spike-sample equilibration. Garnet separate samples were spiked for both Sm-Nd and Lu-Hf within the same dissolution. The Hf and Lu were collected and purified following procedures from Carlson et al. (2006).

Sm and Nd isotopic compositions were measured using double Re filaments in the Department of Terrestrial Magnetism (DTM) Thermo-Fisher Triton thermal ionization mass spectrometer. Mass spectrometric procedures followed those described in Carlson et al. (2007). The ${ }^{147} \mathrm{Sm} /{ }^{144} \mathrm{Nd}$ ratios as well as the Sm and Nd concentrations reported in Table 1 were measured on the spiked aliquots whereas all other reported isotopic data were obtained on the unspiked aliquots. $\mathrm{Nd}$ is measured as $\mathrm{Nd}+$ in a two-step dynamic routine that provides static measurements of all $\mathrm{Nd}$ isotope ratios and ${ }^{138} \mathrm{Ba},{ }^{140} \mathrm{Ce},{ }^{141} \mathrm{Pr}$, and ${ }^{147} \mathrm{Sm}$, and also provides a dynamic measurement for ${ }^{142} \mathrm{Nd} /{ }^{144} \mathrm{Nd}$. Individual runs consist of 540 ratios taken with 8 second integrations per mass step. When the amount of $\mathrm{Nd}$ on the filaments allowed, samples were run more than once on the same filament. Samples that were run multiple times from the same filament were combined into one run of $540+$ ratios. Data were corrected for instrumental mass fractionation using the exponential law to ${ }^{146} \mathrm{Nd} /{ }^{144} \mathrm{Nd}=0.7219$. Total Nd blank for the flux-fusion technique is $2.6 \mathrm{ng}$. Considering 
Table 1

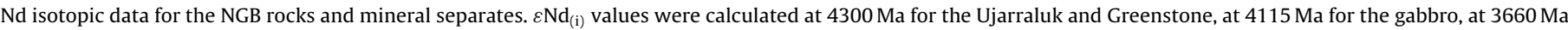
for the tonalite, at $3800 \mathrm{Ma}$ for the trodhjemite band and at $2700 \mathrm{Ma}$ for the pegmatite.

\begin{tabular}{|c|c|c|c|c|c|c|c|c|c|}
\hline Sample & Lithology & {$[\mathrm{Nd}](\mathrm{ppm})$} & {$[\mathrm{Sm}](\mathrm{ppm})$} & ${ }^{147} \mathrm{Sm} /{ }^{144} \mathrm{Nd}$ & ${ }^{143} \mathrm{Nd} /{ }^{144} \mathrm{Nd} \pm 2 \sigma$ & $\varepsilon \mathrm{Nd}_{(i)}$ & $T_{\mathrm{DM}}(\mathrm{Ga})$ & ${ }^{142} \mathrm{Nd} /{ }^{144} \mathrm{Nd} \pm 2 \sigma$ & $\mu^{142} \mathrm{Nd} \pm 2 \sigma$ \\
\hline \multicolumn{10}{|c|}{ High-Ti group } \\
\hline PC-058 & Ujaraaluk & 19.56 & 3.91 & 0.1207 & $0.510809 \pm 1$ & 6.4 & 3.8 & $1.1418354 \pm 39$ & $0.0 \pm 3.4$ \\
\hline PC-129a & Ujaraaluk & 8.07 & 2.10 & 0.1571 & $0.511818 \pm 2$ & 5.8 & 3.5 & $1.1418239 \pm 45$ & $-10.1 \pm 3.9$ \\
\hline PC-132 & Ujaraaluk & 6.13 & 1.83 & 0.1818 & $0.512386 \pm 16$ & 3.2 & 3.5 & $1.1418263 \pm 66$ & $-8.0 \pm 5.8$ \\
\hline PC-171 & Ujaraaluk & 15.34 & 5.24 & 0.2073 & $0.512870 \pm 3$ & -1.6 & & $1.1418386 \pm 50$ & $2.8 \pm 4.4$ \\
\hline PC-180 & Greenstone & 5.16 & 1.61 & 0.1890 & $0.512572 \pm 1$ & 2.8 & 3.4 & $1.1418361 \pm 58$ & $0.6 \pm 5.1$ \\
\hline PC-421 & Ujaraaluk & 4.26 & 1.41 & 0.2012 & $0.512802 \pm 2$ & 0.4 & 4.3 & $1.1418421 \pm 50$ & $5.8 \pm 4.4$ \\
\hline PC-423 & Ujaraaluk & 7.16 & 2.13 & 0.1810 & $0.512221 \pm 3$ & 0.4 & 4.3 & $1.1418317 \pm 52$ & $-3.3 \pm 4.5$ \\
\hline PC-425 & Ujaraaluk & 4.33 & 1.11 & 0.1559 & $0.511898 \pm 3$ & 8.1 & 3.2 & $1.1418289 \pm 56$ & $-5.7 \pm 4.9$ \\
\hline PC-429 & Ujaraaluk & 8.54 & 2.24 & 0.1595 & $0.511765 \pm 1$ & 3.5 & 3.8 & $1.1418287 \pm 37$ & $-5.9 \pm 3.2$ \\
\hline PC-451 & Greenstone & 11.77 & 2.75 & 0.1412 & $0.511345 \pm 1$ & 5.5 & 3.7 & $1.1418314 \pm 27$ & $-3.6 \pm 2.4$ \\
\hline PC-220 & Ultramafic & 4.04 & 1.46 & 0.2192 & $0.513219 \pm 5$ & -1.4 & 3.0 & $1.1418422 \pm 63$ & $5.9 \pm 5.5$ \\
\hline PC-018 & Ultramafic & 1.51 & 0.61 & 0.2452 & $0.513658 \pm 8$ & -7.4 & 2.7 & $1.1418445 \pm 62$ & $8.0 \pm 5.4$ \\
\hline PC-033 & Ultramafic & 3.76 & 1.28 & 0.2062 & $0.512944 \pm 1$ & 0.5 & 4.3 & $1.1418411 \pm 43$ & $5.0 \pm 3.8$ \\
\hline \multicolumn{10}{|c|}{ Depleted low-Ti group } \\
\hline PC-131 & Ujaraaluk & 2.44 & 0.66 & 0.1643 & $0.511875 \pm 2$ & 2.9 & 3.9 & $1.1418234 \pm 58$ & $-10.5 \pm 5.1$ \\
\hline PC-151 & Ujaraaluk & 2.55 & 0.81 & 0.1919 & $0.512433 \pm 2$ & -1.6 & & & \\
\hline PC-184 & Greenstone & 2.42 & 0.63 & 0.1572 & $0.511848 \pm 1$ & 6.4 & 3.4 & $1.1418211 \pm 54$ & $-12.6 \pm 4.8$ \\
\hline PC-222 & Ujaraaluk & 2.70 & 0.81 & 0.1825 & $0.512216 \pm 2$ & -0.6 & & $1.1418264 \pm 46$ & $-7.9 \pm 4.0$ \\
\hline PC-227 & Ujaraaluk & 2.29 & 0.81 & 0.2144 & $0.512753 \pm 1$ & -7.9 & & $1.1418372 \pm 39$ & $1.5 \pm 3.5$ \\
\hline PC $-230^{\mathrm{a}}$ & Ujaraaluk & 2.44 & 0.72 & 0.1793 & $0.512137 \pm 14$ & -0.3 & 4.5 & $1.1418272 \pm 9$ & $-7.2 \pm 0.8$ \\
\hline PC-410 & Ujaraaluk & 2.37 & 0.65 & 0.1673 & $0.511927 \pm 3$ & 2.3 & 4.0 & $1.1418296 \pm 63$ & $-5.1 \pm 5.5$ \\
\hline PC-412 & Ujaraaluk & 1.62 & 0.55 & 0.2059 & $0.512601 \pm 1$ & -6.2 & & $1.1418371 \pm 47$ & $1.5 \pm 4.1$ \\
\hline PC-432 & Ujaraaluk & 2.86 & 0.78 & 0.1662 & $0.511983 \pm 2$ & 4.0 & 3.7 & $1.1418286 \pm 58$ & $-6.0 \pm 5.0$ \\
\hline PC-433 & Ujaraaluk & 2.05 & 0.59 & 0.1736 & $0.512110 \pm 3$ & 2.3 & 3.9 & $1.1418251 \pm 82$ & $-9.1 \pm 7.2$ \\
\hline PC-214 & Ultramafic & 0.14 & 0.06 & 0.2681 & $0.514124 \pm 16$ & -11.1 & 2.8 & $1.1418419 \pm 71$ & $5.7 \pm 6.2$ \\
\hline \multicolumn{10}{|c|}{ Enriched low-Ti group } \\
\hline PC-149a & Ujaraaluk & 4.75 & 1.27 & 0.1618 & $0.511691 \pm 0.3$ & 0.7 & 4.3 & $1.1418230 \pm 10$ & $-10.9 \pm 0.9$ \\
\hline PC $-152^{c}$ & Ujaraaluk & 9.41 & 2.08 & 0.1343 & $0.511090 \pm 3$ & 4.3 & 3.9 & $1.1418266 \pm 5$ & $-7.7 \pm 2.0$ \\
\hline PC-162 & Ujaraaluk & 5.17 & 1.39 & 0.1626 & $0.511602 \pm 3$ & -1.5 & & $1.1418313 \pm 38$ & $-3.6 \pm 3.3$ \\
\hline PC-185 & Greenstone & 8.30 & 1.95 & 0.1421 & $0.511244 \pm 1$ & 3.0 & 4.0 & $1.1418182 \pm 26$ & $-15.1 \pm 2.3$ \\
\hline PC-186 & Greenstone & 6.44 & 1.50 & 0.1411 & $0.511166 \pm 1$ & 2.0 & 4.1 & $1.1418189 \pm 66$ & $-14.5 \pm 5.8$ \\
\hline PC-225 & Ujaraaluk & 8.99 & 2.17 & 0.1462 & $0.511363 \pm 5$ & 3.0 & 4.0 & $1.1418187 \pm 56$ & $-14.7 \pm 4.9$ \\
\hline PC $-250^{c}$ & Ujaraaluk & 9.36 & 2.00 & 0.1297 & $0.511050 \pm 3$ & 6.2 & 3.8 & $1.1418200 \pm 43$ & $-13.5 \pm 3.8$ \\
\hline PC $-251^{\mathrm{a}}$ & Ujaraaluk & 7.95 & 1.88 & 0.1429 & $0.511177 \pm 15$ & 1.2 & 4.2 & $1.1418185 \pm 21$ & $-14.9 \pm 1.8$ \\
\hline PC-267 & Ujaraaluk & 9.50 & 2.29 & 0.1458 & $0.511225 \pm 4$ & 0.5 & 4.3 & $1.1418194 \pm 90$ & $-14.1 \pm 7.9$ \\
\hline PC- $275^{c}$ & Ujaraaluk & 10.48 & 2.34 & 0.1355 & $0.510976 \pm 5$ & 1.4 & 4.2 & $1.1418212 \pm 77$ & $-12.5 \pm 6.8$ \\
\hline PC-276 ${ }^{\mathrm{a}}$ & Ujaraaluk & 7.55 & 2.00 & 0.1602 & $0.511557 \pm 9$ & -1.0 & 4.5 & $1.1418245 \pm 34$ & $-9.6 \pm 3.0$ \\
\hline PC-278 & Ujaraaluk & 9.43 & 2.17 & 0.1399 & $0.511228 \pm 3$ & 3.9 & 3.9 & $1.1418180 \pm 55$ & $-15.3 \pm 4.8$ \\
\hline PC- $282^{\mathrm{a}, \mathrm{d}}$ & Ujaraaluk & 9.58 & 2.45 & 0.1543 & $0.511420 \pm 0$ & -0.4 & 4.4 & $1.1418216 \pm 49$ & $-12.1 \pm 4.3$ \\
\hline PC-438 & Ujaraaluk & 7.51 & 1.65 & 0.1343 & $0.511089 \pm 3$ & 4.3 & 3.9 & $1.1418240 \pm 55$ & $-10.0 \pm 4.8$ \\
\hline PC-442 & Ujaraaluk & 4.39 & 1.12 & 0.1544 & $0.511420 \pm 3$ & -0.5 & 4.4 & $1.1418225 \pm 68$ & $-11.3 \pm 6.0$ \\
\hline PC $-443^{\mathrm{C}}$ & Ujaraaluk & 3.15 & 0.95 & 0.1825 & $0.512154 \pm 2$ & -1.8 & & $1.1418271 \pm 6$ & $-7.3 \pm 2.9$ \\
\hline PC $-452^{c}$ & Ujaraaluk & 9.36 & 2.05 & 0.1377 & $0.511188 \pm 3$ & 4.4 & 3.9 & $1.1418227 \pm 24$ & $-11.1 \pm 3.7$ \\
\hline PC-456 & Greenstone & 9.54 & 2.17 & 0.1378 & $0.511208 \pm 1$ & 4.7 & 3.9 & $1.1418149 \pm 59$ & $-18.0 \pm 5.2$ \\
\hline PC-532 & Ujaraaluk & 7.98 & 2.15 & 0.1631 & $0.511935 \pm 6$ & 4.8 & 3.6 & $1.1418317 \pm 34$ & $-3.3 \pm 3.0$ \\
\hline PC-071 & Ultramafic & 6.42 & 1.70 & 0.1603 & $0.511894 \pm 1$ & 5.5 & 3.5 & $1.1418340 \pm 42$ & $-1.3 \pm 3.7$ \\
\hline PC-075 & Ultramafic & 2.13 & 0.61 & 0.1737 & $0.512191 \pm 1$ & 3.9 & 3.6 & $1.1418282 \pm 26$ & $-6.4 \pm 2.3$ \\
\hline PC-137 & Ultramafic & 4.90 & 1.49 & 0.1846 & $0.512351 \pm 3$ & 0.9 & 4.2 & $1.1418317 \pm 69$ & $-3.2 \pm 6.1$ \\
\hline PC-142 & Ultramafic & 7.04 & 1.94 & 0.1674 & $0.512060 \pm 3$ & 4.9 & 3.5 & $1.1418366 \pm 38$ & $1.0 \pm 3.3$ \\
\hline PC-213 & Ultramafic & 2.04 & 0.69 & 0.2034 & $0.512657 \pm 1$ & -3.6 & & $1.1418406 \pm 44$ & $4.6 \pm 3.9$ \\
\hline PC-218 & Ultramafic & 6.91 & 2.22 & 0.1945 & $0.512569 \pm 2$ & -0.3 & & $1.1418335 \pm 13$ & $-1.7 \pm 1.1$ \\
\hline PC-307 & Ultramafic & 2.57 & 0.81 & 0.1914 & $0.512422 \pm 1$ & -1.5 & & $1.1418373 \pm 57$ & $1.6 \pm 5.0$ \\
\hline PC-309 & Ultramafic & 5.25 & 1.54 & 0.1779 & $0.512258 \pm 3$ & 2.8 & 3.7 & $1.1418386 \pm 52$ & $2.8 \pm 4.6$ \\
\hline PC-503 & Ultramafic & 2.26 & 0.69 & 0.1856 & $0.512286 \pm 1$ & -0.9 & & $1.1418319 \pm 64$ & $-3.1 \pm 5.6$ \\
\hline PC-506 & Ultramafic & 7.36 & 2.06 & 0.1689 & $0.511995 \pm 1$ & 2.7 & 3.9 & $1.1418357 \pm 31$ & $0.3 \pm 2.7$ \\
\hline \multicolumn{10}{|c|}{ Central gabbro } \\
\hline$P C-221^{a}$ & Gabbro & 7.12 & 2.16 & 0.1835 & $0.512395 \pm 14$ & 2.1 & 3.7 & $1.1418337 \pm 42$ & $-1.5 \pm 3.7$ \\
\hline PC-228 & Gabbro & 5.46 & 1.37 & 0.1515 & $0.511532 \pm 15$ & 2.3 & 3.9 & & \\
\hline PC- $248^{\mathrm{a}, \mathrm{d}}$ & Gabbro & 7.20 & 2.27 & 0.1903 & $0.512591 \pm 11$ & 2.3 & 3.5 & $1.1418318 \pm 31$ & $-3.1 \pm 2.7$ \\
\hline$P C-253^{a}$ & Gabbro & 8.34 & 2.67 & 0.1932 & $0.512669 \pm 10$ & 2.3 & 3.4 & & \\
\hline PC-254 & Gabbro & 8.90 & 2.12 & 0.1442 & $0.511331 \pm 11$ & 2.3 & 3.9 & & \\
\hline PC $-255^{\mathrm{a}}$ & Gabbro & 7.47 & 2.34 & 0.1893 & $0.512534 \pm 23$ & 1.7 & 3.7 & & \\
\hline PC $-259^{a}$ & Gabbro & 6.82 & 2.29 & 0.2034 & $0.512909 \pm 10$ & 1.5 & 3.0 & & \\
\hline PC-268 ${ }^{\mathrm{a}}$ & Gabbro & 6.58 & 2.08 & 0.1908 & $0.512557 \pm 11$ & 1.4 & 3.9 & & \\
\hline PC-508 & Gabbro & 10.42 & 2.55 & 0.1481 & $0.511430 \pm 5$ & 2.1 & 3.9 & $1.1418260 \pm 27$ & $-8.3 \pm 2.4$ \\
\hline PC-511 & Gabbro & 8.99 & 2.26 & 0.1522 & $0.511572 \pm 5$ & 2.7 & 3.9 & $1.1418265 \pm 38$ & $-7.8 \pm 3.3$ \\
\hline PC-512 & Gabbro & 10.12 & 2.50 & 0.1494 & $0.511444 \pm 6$ & 1.7 & 4.0 & $1.1418284 \pm 34$ & $-6.2 \pm 3.0$ \\
\hline PC-522 & Gabbro & 2.71 & 0.80 & 0.1788 & $0.512181 \pm 6$ & 0.4 & 4.2 & $1.1418351 \pm 49$ & $-0.3 \pm 4.3$ \\
\hline PC-523 & Gabbro & 7.01 & 1.65 & 0.1424 & $0.511233 \pm 7$ & 1.3 & 4.1 & $1.1418295 \pm 60$ & $-5.2 \pm 5.2$ \\
\hline PC-525 & Gabbro & 7.66 & 1.83 & 0.1442 & $0.511278 \pm 6$ & 1.2 & 4.1 & & \\
\hline
\end{tabular}




\begin{tabular}{|c|c|c|c|c|c|c|c|c|c|}
\hline Sample & Lithology & {$[\mathrm{Nd}](\mathrm{ppm})$} & {$[\mathrm{Sm}](\mathrm{ppm})$} & ${ }^{147} \mathrm{Sm} /{ }^{144} \mathrm{Nd}$ & ${ }^{143} \mathrm{Nd} /{ }^{144} \mathrm{Nd} \pm 2 \sigma$ & $\varepsilon \mathrm{Nd}_{(i)}$ & $T_{\mathrm{DM}}(\mathrm{Ga})$ & ${ }^{142} \mathrm{Nd} /{ }^{144} \mathrm{Nd} \pm 2 \sigma$ & $\mu^{142} \mathrm{Nd} \pm 2 \sigma$ \\
\hline \multicolumn{10}{|l|}{ Felsic rocks } \\
\hline PC-103 & Tonalite & 20.81 & 3.76 & 0.1092 & $0.510245 \pm 2$ & -5.6 & 4.2 & $1.1418215 \pm 61$ & $-12.2 \pm 5.3$ \\
\hline PC-104 & Tonalite & 23.37 & 3.64 & 0.0941 & $0.510049 \pm 1$ & -2.2 & 3.9 & $1.1418221 \pm 37$ & $-11.7 \pm 3.3$ \\
\hline PC-105 & Tonalite & 20.02 & 3.34 & 0.1009 & $0.510199 \pm 1$ & -2.5 & 3.9 & $1.1418286 \pm 45$ & $-6.0 \pm 3.9$ \\
\hline PC-106 & Tonalite & 20.90 & 3.08 & 0.0891 & $0.509932 \pm 1$ & -2.1 & 3.9 & $1.1418191 \pm 34$ & $-14.3 \pm 3.0$ \\
\hline PC-169 & Tonalite & 13.60 & 2.15 & 0.0954 & $0.510119 \pm 1$ & -1.5 & 3.9 & $1.1418239 \pm 49$ & $-10.1 \pm 4.3$ \\
\hline PC-286 & Tonalite & 20.80 & 3.74 & 0.1087 & $0.510106 \pm 2$ & -8.1 & 4.4 & $1.1418169 \pm 72$ & $-16.2 \pm 6.3$ \\
\hline POR23 $3^{\mathrm{b}}$ & Tonalite & 21.60 & 3.66 & 0.1025 & $0.510263 \pm 8$ & -2.0 & 3.9 & & \\
\hline POR23-2 ${ }^{\mathrm{b}}$ & Tonalite & 21.10 & 3.56 & 0.1017 & $0.510271 \pm 14$ & -1.5 & 3.9 & & \\
\hline WP59 & Tonalite & 25.50 & 4.09 & 0.0968 & $0.510140 \pm 8$ & -1.7 & 3.9 & & \\
\hline WP104 & Tonalite & 36.40 & 4.81 & 0.0799 & $0.509737 \pm 8$ & -1.6 & 3.8 & & \\
\hline WP69b ${ }^{b}$ & Tonalite & 23.30 & 4.22 & 0.1096 & $0.510497 \pm 9$ & -0.8 & 3.8 & & \\
\hline WP67 ${ }^{\mathrm{b}}$ & Tonalite & 14.10 & 2.20 & 0.0943 & $0.510117 \pm 9$ & -1.0 & 3.8 & & \\
\hline PC $-101^{\mathrm{a}}$ & Trond. Band & 15.14 & 2.48 & 0.0989 & $0.510249 \pm 10$ & 1.2 & 3.8 & $1.1418249 \pm 68$ & $-9.2 \pm 5.9$ \\
\hline PC $-102^{\mathrm{a}}$ & Trond. Band & 17.85 & 2.87 & 0.0972 & $0.510173 \pm 10$ & 0.6 & 3.8 & $1.1418241 \pm 64$ & $-9.9 \pm 5.6$ \\
\hline PC-287 & Trond. Band & 13.87 & 2.16 & 0.0940 & $0.510090 \pm 1$ & 0.5 & 3.9 & $1.1418254 \pm 34$ & $-8.8 \pm 3.0$ \\
\hline R18 & Pegmatite & 7.18 & 1.50 & 0.1260 & $0.510738 \pm 1$ & -12.7 & 4.2 & $1.1418230 \pm 34$ & $-10.9 \pm 3.0$ \\
\hline \multicolumn{10}{|c|}{ Mineral separate } \\
\hline PC-230GRT & Garnet & 0.40 & 1.05 & 1.6053 & $0.536509 \pm 20$ & & & & \\
\hline PC-267GRT & Garnet & 2.11 & 1.49 & 0.4269 & $0.516282 \pm 5$ & & & & \\
\hline PC-275GRT & Garnet & 2.06 & 1.55 & 0.4552 & $0.516651 \pm 7$ & & & & \\
\hline PC-276GRT & Garnet & 4.30 & 2.37 & 0.3333 & $0.514457 \pm 13$ & & & & \\
\hline PC-276BT & Biotite & 0.52 & 0.08 & 0.0938 & $0.510886 \pm 24$ & & & & \\
\hline PC-282GRT & Garnet & 1.48 & 0.95 & 0.3896 & $0.515415 \pm 11$ & & & & \\
\hline PC-438GRT & Garnet & 1.25 & 0.67 & 0.3250 & $0.514299 \pm 14$ & & & & \\
\hline PC-536GRT & Garnet & 2.33 & 0.74 & 0.1924 & $0.512176 \pm 9$ & & & & \\
\hline PC-085WR & Gabbro & 7.18 & 2.32 & 0.1956 & $0.512722 \pm 1$ & & & & \\
\hline PC-085PL & Plagioclase & 0.53 & 0.10 & 0.1146 & $0.511261 \pm 45$ & & & & \\
\hline PC-085HBL & Hornblende & 9.81 & 3.22 & 0.1987 & $0.512762 \pm 24$ & & & & \\
\hline
\end{tabular}

a Data from O'Neil et al. (2008).

b Data from David et al. (2009).

c Average $\mu^{142} \mathrm{Nd}$ value for duplicate samples (see Table SD3).

d Average $\mu^{142} \mathrm{Nd}$ value for duplicate samples including data from O'Neil et al. (2008) (see Table SD3).

$2 \sigma$ errors for ${ }^{143} \mathrm{Nd} /{ }^{144} \mathrm{Nd}$ and ${ }^{142} \mathrm{Nd} /{ }^{144} \mathrm{Nd}$ are in the last decimal place.

that between 700 and $500 \mathrm{ng}$ of $\mathrm{Nd}$ were analyzed for a sample, the Nd blank represents at most $0.5 \%$ of the total $\mathrm{Nd}$ analyzed. Repeated measurements of the JNdi- 1 standard yielded a long-term dynamically measured value of ${ }^{142} \mathrm{Nd} /{ }^{144} \mathrm{Nd}=1.1418354(n=41$, with most JNdi-1 standards analyzed twice on the same filament) with an external reproducibility ( $2 \sigma$, not $2 \sigma$-mean) of $4.5 \mathrm{ppm}$ for the period of the study (Table SD4). The chondritic reference values used for $\varepsilon \mathrm{Nd}$ calculations are; ${ }^{143} \mathrm{Nd} /{ }^{144} \mathrm{Nd}$ CHUR $=0.51263$, ${ }^{147} \mathrm{Sm} /{ }^{144} \mathrm{Nd}$ CHUR $=0.196$ (Bouvier et al., 2008). Values used for $\mathrm{Nd}$ model age calculations are present day ${ }^{143} \mathrm{Nd} /{ }^{144} \mathrm{Nd}=0.51301$ and ${ }^{147} \mathrm{Sm} /{ }^{144} \mathrm{Nd}=0.2085$ reflecting a non-chondritic bulk Earth composition that today would have the $18 \mathrm{ppm}$ excess ${ }^{142} \mathrm{Nd} /{ }^{144} \mathrm{Nd}$ observed in the modern terrestrial mantle compared to average ordinary chondrite (Carlson and Boyet, 2008). Initial $\varepsilon^{143} \mathrm{Nd}$ and uncertainty were calculated following Fletcher and Rosman (1982). Initial $\mu^{142} \mathrm{Nd}$ were determined from isochrons and normalized to a depleted mantle (DM) reservoir with ${ }^{147} \mathrm{Sm} /{ }^{144} \mathrm{Nd}=0.2085$ and $\mu^{142} \mathrm{Nd}=0$. The decay constant used for ${ }^{147} \mathrm{Sm}$ is $6.54 \times 10^{-12} \mathrm{yr}^{-1}$ and $1.02 \times 10^{-8} \mathrm{yr}^{-1}$ for ${ }^{146} \mathrm{Sm}$. For the ${ }^{142} \mathrm{Nd}$ analysis, corrections for both $\mathrm{Ce}$ and $\mathrm{Sm}$ interference were made prior to mass fractionation correction. ${ }^{140} \mathrm{Ce} /{ }^{146} \mathrm{Nd}$ ratios ranged from $8.4 \times 10^{-7}$ to $8.3 \times 10^{-4}$ with 52 out of 62 samples having ${ }^{140} \mathrm{Ce} /{ }^{146} \mathrm{Nd}<10^{-4}$. The measured ${ }^{147} \mathrm{Sm} /{ }^{146} \mathrm{Nd}$ ratio during $\mathrm{Nd}$ runs averaged $3.1 \times 10^{-6}$ with only 2 samples exceeding $1 \times 10^{-5}$. One sample (PC-220) yielded higher ${ }^{140} \mathrm{Ce} /{ }^{146} \mathrm{Nd}$ and ${ }^{147} \mathrm{Sm} /{ }^{146} \mathrm{Nd}$ ratios of $1.24 \times 10^{-3}$ and $1.7 \times 10^{-4}$ respectively.

The ${ }^{143} \mathrm{Nd} /{ }^{144} \mathrm{Nd}$ and ${ }^{147} \mathrm{Sm} /{ }^{144} \mathrm{Nd}$ ratios for PC-085 (whole rock, hornblende and plagioclase separates) as well as the biotite separate for PC-276 were analyzed at the GEOTOP laboratories (Université du Québec à Montréal) following the procedure described in O'Neil et al. (2008)

The $\mu^{142} \mathrm{Nd}\left[\left(\left(\left({ }^{142} \mathrm{Nd} /{ }^{144} \mathrm{Nd}\right)_{\text {sample }} /\left({ }^{142} \mathrm{Nd} /{ }^{144} \mathrm{Nd}\right)_{\text {JNdi- } 1}\right)-1\right) \times\right.$ $10^{6}$ ] for each sample was calculated using the average $\left({ }^{142} \mathrm{Nd} /{ }^{144} \mathrm{Nd}\right)_{\text {JNdi-1 }}$ ratio within the same barrel used for sample analysis. In order to compare the ${ }^{142} \mathrm{Nd} /{ }^{144} \mathrm{Nd}$ ratios for samples from different barrels, the ${ }^{142} \mathrm{Nd} /{ }^{144} \mathrm{Nd}$ ratios for each sample reported in Table 1 were calculated using their $\mu^{142} \mathrm{Nd}$ re-normalized to the long-term ${ }^{142} \mathrm{Nd} /{ }^{144} \mathrm{Nd}$ ratio for JNdi- 1 of ${ }^{142} \mathrm{Nd} /{ }^{144} \mathrm{Nd}=1.1418354$. The same re-normalization was applied to data from O'Neil et al. (2008) to allow comparisons of both studies. No correlation exists between ${ }^{142} \mathrm{Nd} /{ }^{144} \mathrm{Nd}$ and ${ }^{140} \mathrm{Ce} /{ }^{146} \mathrm{Nd}$ or ${ }^{147} \mathrm{Sm} /{ }^{146} \mathrm{Nd}$ in samples or standards (Fig. SD3) suggesting that Ce and Sm interferences do not affect the data. Sample PC-220 has higher Sm and Ce interferences (Table SD2) but still does not display any correlation between ${ }^{142} \mathrm{Nd} /{ }^{144} \mathrm{Nd}$ and ${ }^{140} \mathrm{Ce} /{ }^{146} \mathrm{Nd}$ or ${ }^{147} \mathrm{Sm} /{ }^{146} \mathrm{Nd}$ (Fig. SD3) and has a ${ }^{142} \mathrm{Nd}$ isotopic composition consistent with other samples from the same geochemical group. Sample PC-456 has the lowest $\mu^{142} \mathrm{Nd}$ value ( -18 ; Table 1 ) but with very small $\mathrm{Sm}$ and Ce interferences (Table SD2) and without any correlation between ${ }^{142} \mathrm{Nd} /{ }^{144} \mathrm{Nd}$ and ${ }^{140} \mathrm{Ce} /{ }^{146} \mathrm{Nd}$ or ${ }^{147} \mathrm{Sm} /{ }^{146} \mathrm{Nd}$ (Fig. SD3) supporting the fact that the measured $\mu^{142} \mathrm{Nd}$ values are not artifacts due to mass interferences and represent the real ${ }^{142} \mathrm{Nd} /{ }^{144} \mathrm{Nd}$ isotopic compositions of the samples. There also is no correlation between the ${ }^{142} \mathrm{Nd} /{ }^{144} \mathrm{Nd}$ ratios for the samples and their ${ }^{145} \mathrm{Nd} /{ }^{144} \mathrm{Nd},{ }^{148} \mathrm{Nd} /{ }^{144} \mathrm{Nd}$, and ${ }^{150} \mathrm{Nd} /{ }^{144} \mathrm{Nd}$ ratios (Fig. SD4) indicating that the variability in ${ }^{142} \mathrm{Nd} /{ }^{144} \mathrm{Nd}$ ratio is not due to an incorrect mass dependency for the fractionation correction. Duplicate ${ }^{142} \mathrm{Nd} /{ }^{144} \mathrm{Nd}$ analyses are presented in Table SD3 and Fig. SD2. No variation within error of the ${ }^{142} \mathrm{Nd} /{ }^{144} \mathrm{Nd}$ ratios is observed for duplicate samples. Duplicate samples also reproduce data from O'Neil et al. (2008) for the same sample. Table SD5 shows three ${ }^{142} \mathrm{Nd}$ duplicate analyses of samples from Isua analyzed previously by Rizo et al. (2011). The ${ }^{142} \mathrm{Nd}$ data obtained at DTM that range from $\mu^{142} \mathrm{Nd}$ of +8 to +12 agree within error with the data reported by Rizo et al. (2011) on the same samples. 
Lu-Hf measurements were performed on the DTM Nuplasma multicollector-ICP-MS. Data are fractionation corrected to ${ }^{179} \mathrm{Hf} /{ }^{177} \mathrm{Hf}=0.7325$ and normalized to the average value of ${ }^{176} \mathrm{Hf} /{ }^{177} \mathrm{Hf}$ obtained for the JMC-475 Hf standard $(n=10)$ during the same analytical session as the sample analyses. Values for ${ }^{176} \mathrm{Hf} /{ }^{177} \mathrm{Hf}$ for the JMC-475 standard ranged from 0.282139 to 0.282172 with an average value of $0.282152 \pm 0.000022(2 \sigma$, not $2 \sigma$-mean). All data are reported relative to ${ }^{176} \mathrm{Hf} /{ }^{177} \mathrm{Hf}=0.282160$ for the JMC-475 standard. Total Hf blank for the flux-fusion technique used for the whole rock measurements is $630 \mathrm{pg}$. The garnets were digested in Parr bombs where the total Hf blank is $88 \mathrm{pg}$. Although the Hf blank for the flux-fusion technique is higher, between 250 and $85 \mathrm{ng}$ of $\mathrm{Hf}$ were analyzed for the whole rock samples. The Hf blank thus represents $0.7-0.3 \%$ of the total Hf analyzed. Table SD5 shows two Lu-Hf duplicate analyses of Isua samples previously reported by Rizo et al. (2011). The samples analyzed at DTM were dissolved using the flux-fusion technique and despite the higher blank, agree with the results reported by Rizo et al. (2011) within error.

$\mathrm{U}-\mathrm{Pb}$ geochronology of zircons was conducted at the Laboratoire Magmas et Volcans, Clermont-Ferrand (France). Zircons were first identified directly on polished thin sections using a CAMECA SX 100 electron microprobe and then analyzed by laser ablation inductively coupled plasma spectrometry (LA-ICPMS). Analytical techniques for LA-ICPMS analysis are detailed in Table SD6. The method used for the zircon isotope dating with laser ablation ICP-MS followed the method developed for monazite by Tiepolo (2003) and Paquette and Tiepolo (2007). Concordia ages and diagrams were generated using Isoplot/Ex v. 2.49 software package by Ludwig (2001). The concentrations in $\mathrm{U}-\mathrm{Th}-\mathrm{Pb}$ were calibrated relative to the certified contents of the GJ-1 zircon standard (Jackson et al., 2004).

\section{Results}

4.1. ${ }^{147} \mathrm{Sm}-{ }^{143} \mathrm{Nd}$

\subsubsection{Ujaraaluk unit and cogenetic ultramafic rocks}

Samples from the three different geochemical groups of the Ujaraaluk unit, including samples from the greenstones, were analyzed for their ${ }^{147} \mathrm{Sm}-{ }^{143} \mathrm{Nd}$ isotopic composition along with their respective cogenetic ultramafic sill samples (Table 1 ). The Ujaraaluk mafic rocks display a wide range of ${ }^{147} \mathrm{Sm} /{ }^{144} \mathrm{Nd}$ ratios from substantially subchrondritic to slightly superchondritic (0.1257-0.2143) with ${ }^{143} \mathrm{Nd} /{ }^{144} \mathrm{Nd}$ isotopic compositions ranging from 0.510976 to 0.513219 . The ultramafic sills have higher ${ }^{147} \mathrm{Sm} /{ }^{144} \mathrm{Nd}$ ratios ranging from 0.1603 to 0.2452 with more radiogenic ${ }^{143} \mathrm{Nd} /{ }^{144} \mathrm{Nd}$ compositions from 0.511894 to 0.513658 . Sample PC-214 has a significantly more radiogenic isotopic composition compared to the rest of the ultramafic samples with a ${ }^{147} \mathrm{Sm} /{ }^{144} \mathrm{Nd}$ ratio of 0.2681 and a ${ }^{143} \mathrm{Nd} /{ }^{144} \mathrm{Nd}$ ratio of 0.514124 . This is a sample of a layer of metamorphic orthopyroxene within an ultramafic sill, which may replace an original magmatic cumulate layer. A ${ }^{147} \mathrm{Sm}-{ }^{143} \mathrm{Nd}$ isochron fit to all Ujaraaluk and cogenetic ultramafic samples yields an age of $3598 \pm 200 \mathrm{Ma}$ (Fig. 2A) with an initial $\varepsilon N d$ value of $-1.0 \pm 0.7$. This isochron, however, displays considerable scatter (MSWD $=134$ ) and breaks down into a series of individual correlations with different slopes corresponding to the different geochemical groups within the Ujaraaluk (Fig. 2A). The ${ }^{147} \mathrm{Sm}-{ }^{143} \mathrm{Nd}$ correlation lines fit separately for the high-Ti Ujaraaluk, the depleted low-Ti Ujaraaluk and the enriched low-Ti Ujaraaluk, along with their respective cogenetic ultramafic rocks, yield ages of $3257 \pm 300 \mathrm{Ma}, 2517 \pm 240 \mathrm{Ma}$ and $3734 \pm 300 \mathrm{Ma}$ respectively (Fig. 2B-D). The isochron for the enriched low-Ti Ujaraaluk samples can be further broken down into 2 distinct slopes with younger ages of $2844 \pm 460 \mathrm{Ma}$ and $2685 \pm 470 \mathrm{Ma}$ respectively. These ages have been calculated with the exclusion of 2 high-Ti Ujaraaluk (PC-058, PC-451) samples and one depleted lowTi Ujaraaluk (PC-214) sample. These samples lie well off the best fit lines defined by the remaining samples. We interpret this as reflecting post-magmatic processes that are further discussed in Section 5.2. The Ujaraaluk/ultramafic sills display a wide range of depleted-mantle model ages $\left(T_{\mathrm{DM}}\right)$ mainly ranging from $3.6 \mathrm{Ga}$ to $4.5 \mathrm{Ga}$. A few samples have $T_{\mathrm{DM}} \geq 4.5 \mathrm{Ga}$ most likely due to their near depleted-mantle $\mathrm{Sm} / \mathrm{Nd}$ ratios resulting in an isotopic evolution trend that is sub-parallel to the depleted mantle evolution line. Samples with $T_{\mathrm{DM}}$ values between $3.6 \mathrm{Ga}$ and $4.5 \mathrm{Ga}$ have a bimodal distribution with groupings around $3.9 \mathrm{Ga}$ and $4.3 \mathrm{Ga}$ (Fig. 3A).

\subsubsection{Central gabbro sills}

Gabbro sill samples were collected toward the center of the tight synform. These gabbros display a distinctive fine-scale gneissosity defined by plagioclase-rich and amphibole-rich bands. The gabbros have chondritic to slightly unradiogenic Nd isotopic compositions with ${ }^{147} \mathrm{Sm} /{ }^{144} \mathrm{Nd}$ ratios ranging from 0.2034 to 0.1424 and ${ }^{143} \mathrm{Nd} /{ }^{144} \mathrm{Nd}$ ranging from 0.512909 to 0.511233 (Table 1 ). They define a relatively good isochron (MSWD $=7.2$ ) yielding an age of $4095 \pm 130 \mathrm{Ma}(n=14)$ (Fig. 2E). Only one sample (PC-522) lies off the best fit line. An isochron excluding this sample gives an age of $4115 \pm 100 \mathrm{Ma}(\mathrm{MSWD}=4.8)$ with an initial $\varepsilon \mathrm{Nd}$ value of $+1.9 \pm 0.3$. The gabbro samples in Fig. 2E define 2 clusters in the isochron diagram and hence might represent 2 distinct groups of gabbros. However only fine grained gabbros displaying the same texture and collected along 2 large continuous sill bodies $(35-130 \mathrm{~m}$ in width) that can be traced continuously in the field over $1.5 \mathrm{~km}$, were selected for this isochron. $T_{\mathrm{DM}}$ values for the central gabbro show less variation with the majority of the samples having $T_{\mathrm{DM}}$ values between $3.9 \mathrm{Ga}$ and $4.1 \mathrm{Ga}$ (Fig. 3B).

\subsubsection{NGB felsic rocks}

A new series of felsic rocks from the NGB were analyzed for their ${ }^{147} \mathrm{Sm}-{ }^{143} \mathrm{Nd}$ isotopic composition. These include samples from the $3.6 \mathrm{Ga}$ tonalite surrounding the NGB, the thin bands of 3.8 Ga intruding trondhjemite, and the $2.7 \mathrm{Ga}$ pegmatites (Table 1 ). Tonalite samples and the trondhjemitic band sample show a narrow range of ${ }^{147} \mathrm{Sm} /{ }^{144} \mathrm{Nd}$ ratios from 0.1009 to 0.0891 and ${ }^{143} \mathrm{Nd} /{ }^{144} \mathrm{Nd}$ ranging from 0.510199 to 0.509932 . The Neoarchean pegmatite sample has a slightly higher ${ }^{147} \mathrm{Sm} /{ }^{144} \mathrm{Nd}$ ratio of 0.1260 and a ${ }^{143} \mathrm{Nd} /{ }^{144} \mathrm{Nd}$ ratio of 0.510738 . These values are within the range of isotopic compositions previously reported by O'Neil et al. (2008) and David et al. (2009) for the Nuvvuagittuq felsic rocks. The range in $\mathrm{Sm} / \mathrm{Nd}$ ratios for the tonalities analyzed in this study is too narrow to produce a precise isochron, however, the combined tonalite data from this study, data from O'Neil et al. (2008) and data from David et al. (2009), yields an isochron with an age of $3575 \pm 450 \mathrm{Ma}$ (Fig. 2F) with an initial $\varepsilon \mathrm{Nd}$ value of $-2.9 \pm 0.4$. This isochron is obtained after rejection of 3 samples with higher $\mathrm{Sm} / \mathrm{Nd}$ ratios that clearly fall off the main trend for the tonalities. Despite the large error due to the small range in $\mathrm{Sm} / \mathrm{Nd}$ ratios, this age is in agreement with the $\mathrm{U}-\mathrm{Pb}$ zircon age of $3661 \pm 4 \mathrm{Ma}$ for the Nuvvuagittuq tonalities obtained by David et al. (2009). The Nuvvuagittuq tonalities also have $T_{\mathrm{DM}}$ values systematically older than their crystallization age ranging between $3.8 \mathrm{Ga}$ and $3.9 \mathrm{Ga}$, with 2 samples from O'Neil et al. (2008) yielding $T_{\mathrm{DM}}$ of 4.2 and $4.4 \mathrm{Ga}$ (Fig. 3C) that suggest derivation from an older crustal protolith.

\subsubsection{Mineral separates}

The Sm-Nd isotopic compositions for mineral separates are given in Table 1. Fig. 4A shows the isochron ages obtained from the different mineral separates. All garnet/whole rock tie-lines for 

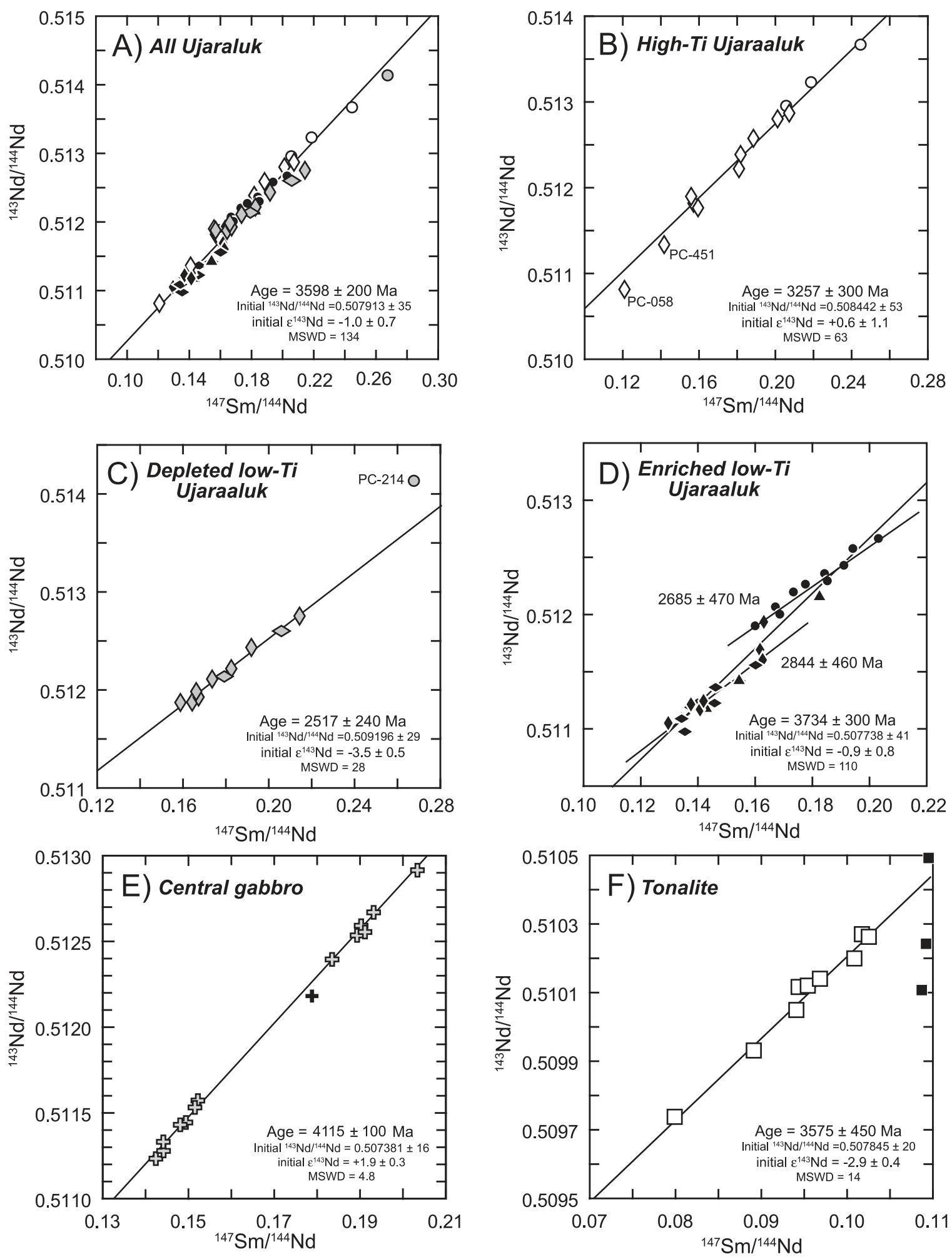

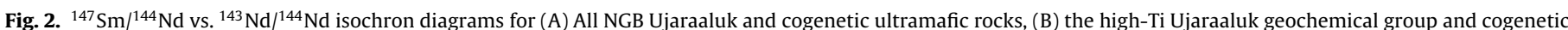

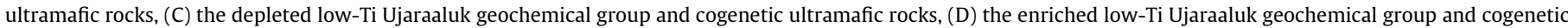

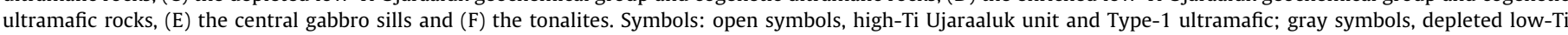

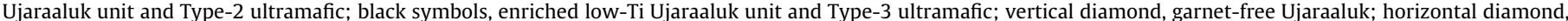

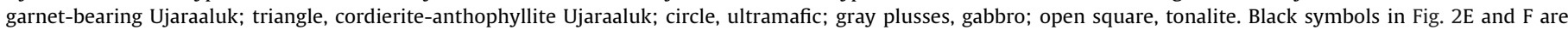
samples not included in the isochron age calculation.

the Ujaraaluk samples ( 7 garnet/whole samples) yield Neoarchean ages ranging from $2537 \mathrm{Ma}$ to $2735 \mathrm{Ma}$ with negative initial $\varepsilon \mathrm{Nd}$ values ranging from -9.4 to -12.4 , with PC-230 having an initial $\varepsilon \mathrm{Nd}$ value of -6.5 (Table SD7). An isochron comprising only garnet from 7 Ujaraaluk samples, including one sample from the lower greenschist metamorphic grade (PC-536 GRT), gives an age of $2619 \pm 50 \mathrm{Ma}$ (Fig. 4B) with an initial $\varepsilon \mathrm{Nd}$ value of $-9.3 \pm 1.8$. The coarse grained gabbro (PC-085) yields an isochron 


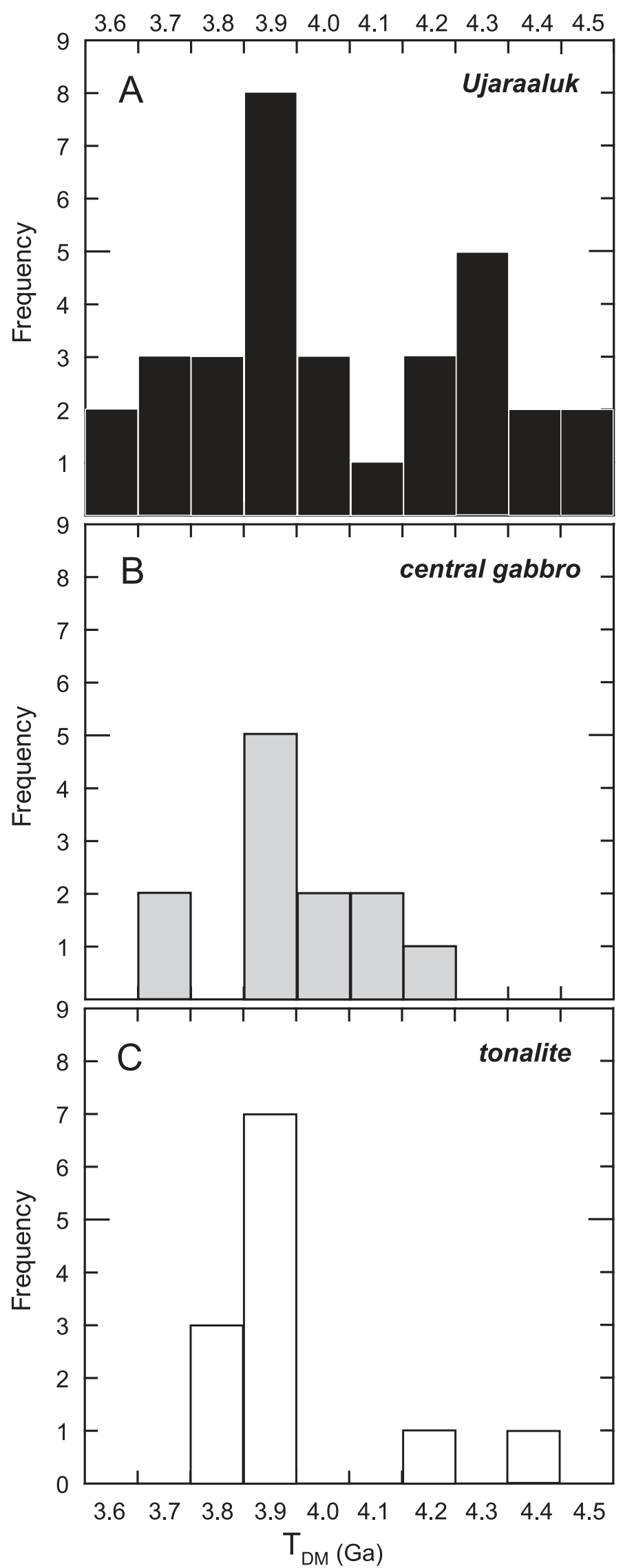

Fig. 3. Histograms of $T_{\mathrm{DM}}$ values for (A) the Ujaraaluk unit, (B) the gabbros and (C) the tonalites. Values used for $\mathrm{Nd}$ model age calculations are present day ${ }^{143} \mathrm{Nd} /{ }^{144} \mathrm{Nd}=0.51301$ and ${ }^{147} \mathrm{Sm} /{ }^{144} \mathrm{Nd}=0.2085$.
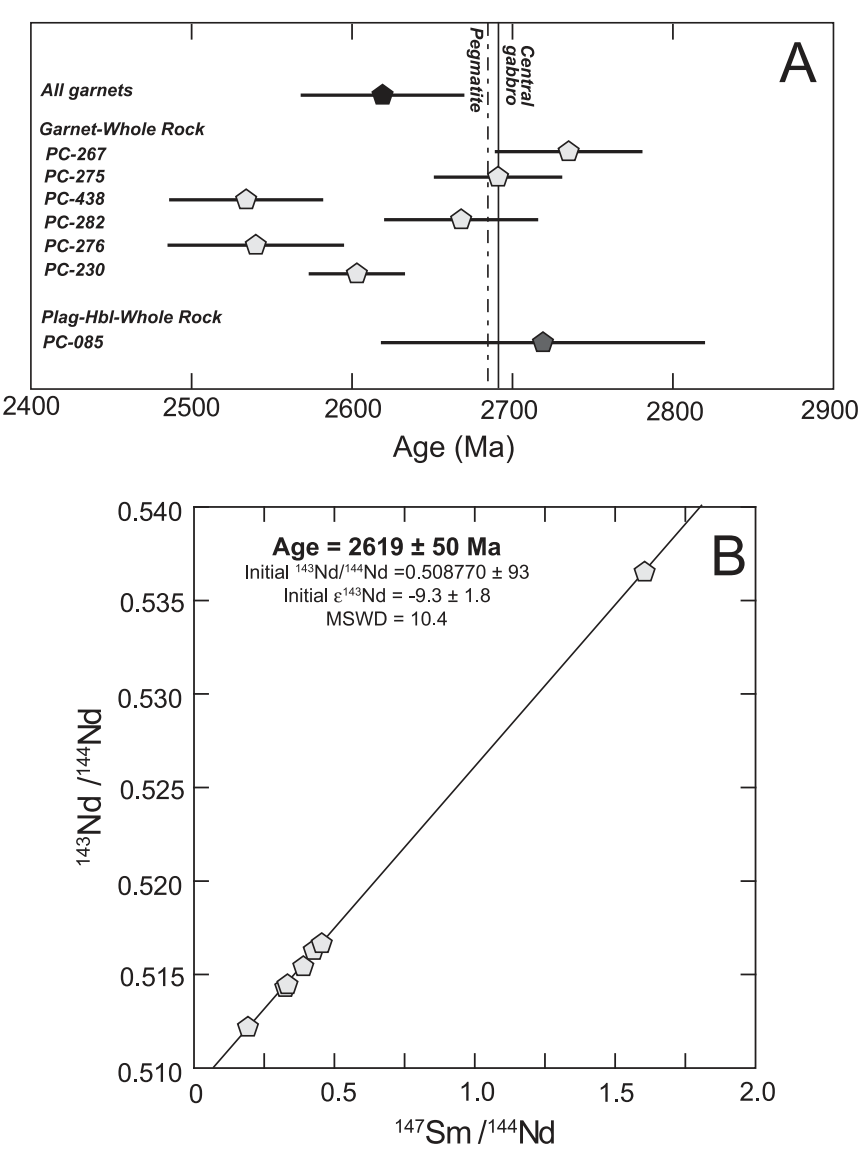

Fig. 4. (A) Sm-Nd isochron ages for garnet separates and mineral/whole rock tielines. Dashed line is the $\mathrm{U}-\mathrm{Pb}$ age of the intruding pegmatite at $2686 \mathrm{Ma}$. Solid vertical line is the $\mathrm{U}-\mathrm{Pb}$ age for zircons from the central gabbros (see Section 4.4). (B) ${ }^{147} \mathrm{Sm} /{ }^{144} \mathrm{Nd}$ vs. ${ }^{143} \mathrm{Nd} /{ }^{144} \mathrm{Nd}$ isochron diagram for all garnet separate samples.

age (hornblende-plagioclase-whole rock) of $2719 \pm 100 \mathrm{Ma}$, but with a positive $\varepsilon \mathrm{Nd}$ value of $+1.8 \pm 0.5$ because the whole rock gabbro has a near chondritic $\mathrm{Sm} / \mathrm{Nd}$ ratio. These Neoarchean ages generally overlap within error with the age for the intrusion of the Nuvvuagittuq pegmatite reported by David et al. (2009) of $2686 \pm 4 \mathrm{Ma}$, as does the imprecise whole rock $\mathrm{Pb}-\mathrm{Pb}$ age of $2.4 \pm 0.4 \mathrm{Ga}$ for the Ujaraaluk samples measured in O'Neil et al. (2008). PC-276, in contrast, yields a Proterozoic biotite-whole rock isochron age of $1537 \mathrm{Ma}$.

\section{2. $\mathrm{Lu}-\mathrm{Hf}$}

Four of the garnet separate samples analyzed for Sm-Nd isotopic composition have also been analyzed for their $\mathrm{Lu}-\mathrm{Hf}$ isotopic composition, along with their whole rock Lu-Hf isotopic composition (Table SD8). ${ }^{176} \mathrm{Lu}-{ }^{176} \mathrm{Hf}$ garnet/whole rock tie-lines for the Ujaraaluk samples give a wide range of Proterozoic ages with, PC230 and PC-275 yielding ages of $1655 \mathrm{Ma}$ and $1599 \mathrm{Ma}$ respectively, whereas PC-282 and PC-438 give younger ages of $1219 \mathrm{Ma}$ and 1157 Ma respectively.

\section{3. ${ }^{142} \mathrm{Nd}$}

The ${ }^{142} \mathrm{Nd}$ isotopic data are presented in Table 1 . The ${ }^{142} \mathrm{Nd} /{ }^{144} \mathrm{Nd}$ ratios of the Ujaraaluk rocks show a $26 \mathrm{ppm}$ variation ranging from samples having an excess in ${ }^{142} \mathrm{Nd}$ (up to $+8 \mathrm{ppm}$ ) to samples having a deficit in ${ }^{142} \mathrm{Nd}$ (up to $-18 \mathrm{ppm}$ ) relative to the terrestrial standard (Fig. 5). The ${ }^{142} \mathrm{Nd} /{ }^{144} \mathrm{Nd}$ ratios for this entire set of samples correlate with their $\mathrm{Sm} / \mathrm{Nd}$ ratios. This correlation 


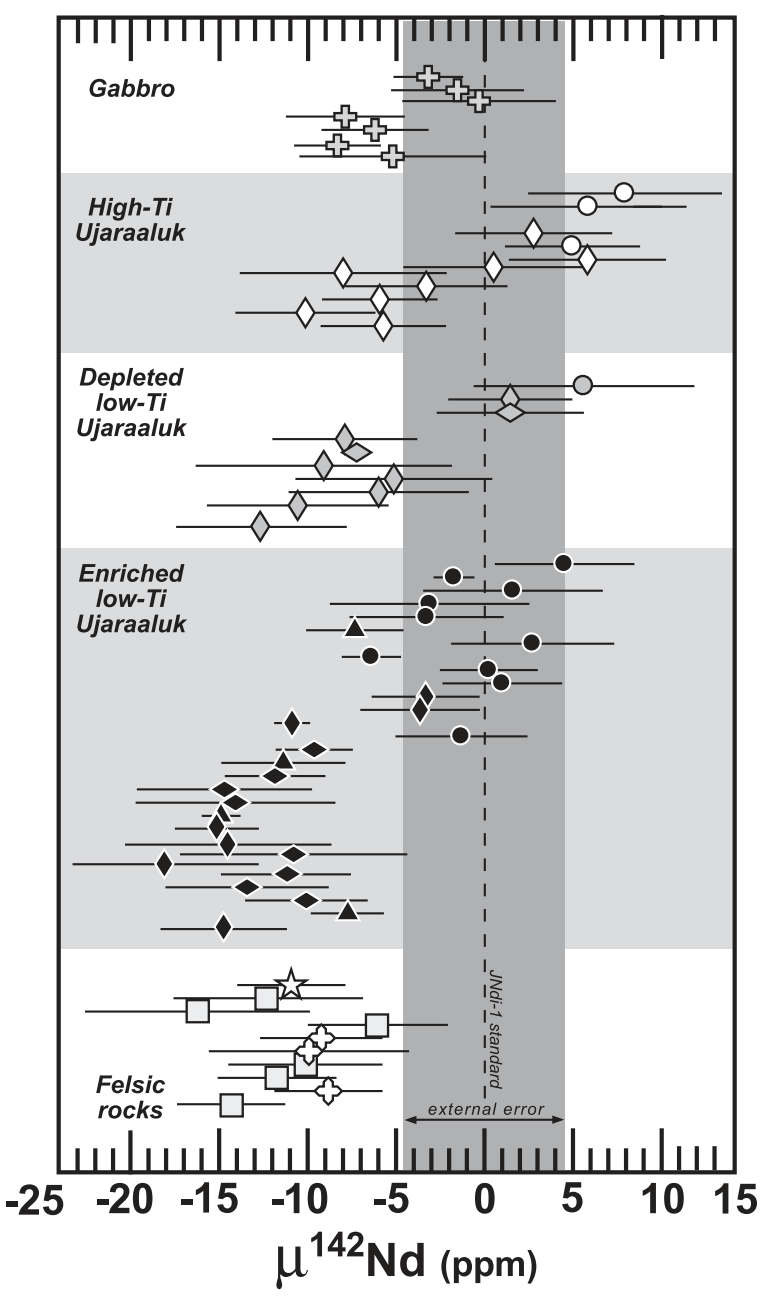

Fig. 5. $\mu^{142} \mathrm{Nd}$ values for all NGB samples relative to the terrestrial Nd standard. Vertical gray band shows the $4.5 \mathrm{ppm}$ external error. Samples are sorted in order of $\mathrm{Sm} / \mathrm{Nd}$ ratios for each different geochemical group/lithology. The different geochemical groups/lithologies are separated by alternating white and gray horizontal zones. Symbols as in Fig. 2; open plusses, trondhjemitic bands; open star, pegmatite.

between the ${ }^{142} \mathrm{Nd} /{ }^{144} \mathrm{Nd}$ ratios and $\mathrm{Sm} / \mathrm{Nd}$ ratios also is present when considering the 3 different geochemical groups of Ujaraaluk individually. The largest deficits in ${ }^{142} \mathrm{Nd}$ are observed in the enriched low-Ti Ujaraaluk, whereas the sample yielding a $\mu^{142} \mathrm{Nd}$ of +8 is an ultramafic rock from the high-Ti Ujaraaluk group. The central gabbro samples also exhibit a correlation between their ${ }^{142} \mathrm{Nd} /{ }^{144} \mathrm{Nd}$ and their ${ }^{147} \mathrm{Sm} /{ }^{144} \mathrm{Nd}$ ratios, but with a smaller range in $\mu^{142} \mathrm{Nd}$ values from 0 to -8 relative to terrestrial standard. All Nuvvuagittuq felsic rocks analyzed, including the tonalities $(-6$ to $-14 \mathrm{ppm})$, the trondhjemitic band ( $-9 \mathrm{ppm})$ and the pegmatite $(-11 \mathrm{ppm})$ yield deficits in ${ }^{142} \mathrm{Nd}$ relative to the terrestrial standard (Fig. 5). There is, however, no correlation between the ${ }^{142} \mathrm{Nd} /{ }^{144} \mathrm{Nd}$ and the ${ }^{147} \mathrm{Sm} /{ }^{144} \mathrm{Nd}$ ratios for any felsic lithology. The ${ }^{142} \mathrm{Nd}$ isotopic data measured in this study are consistent with the data reported by O'Neil et al. (2008) for every lithology, but expands the range of isotopic compositions exhibiting this correlation. The deficits in ${ }^{142} \mathrm{Nd}$ in rocks from the NGB have been confirmed by measurements of the same samples in an independent lab at ETH Zurich (Roth et al., 2011).

\subsection{Zircon $\mathrm{U}-\mathrm{Pb}$}

Zircons from three central gabbro samples have been analyzed by LA-ICP-MS (Table SD9). The analyzed zircons were relatively

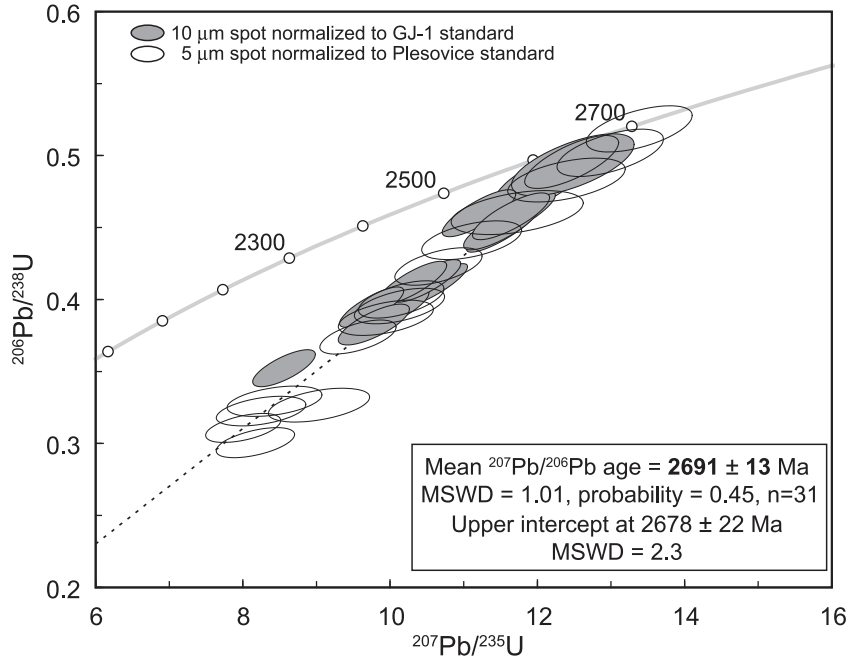

Fig. 6. U-Pb conrcordia diagram for zircons in the central gabbros. Ellipses are $2 \sigma$ error. Solid gray ellipses are for $10 \mu \mathrm{m}$ laser spots normalized to GJ-1 standard and open ellipses are for $5 \mu \mathrm{m}$ laser spots normalized to Plesovice standard.

rounded in shape and between $30 \mu \mathrm{m}$ and $10 \mu \mathrm{m}$ in size with most of them being $\sim 20 \mu \mathrm{m}$. The most concordant zircons $(n=31)$ yield a ${ }^{207} \mathrm{~Pb} /{ }^{206} \mathrm{~Pb}$ age of $2691 \pm 13 \mathrm{Ma}$ (Fig. 6) in agreement with the age of the intrusion of the pegmatite and the metamorphic ages obtained on the mineral separates.

\section{Discussion}

\subsection{Significance of the Ujaraaluk ${ }^{142} \mathrm{Nd}$ isotopic composition}

${ }^{146} \mathrm{Sm}$ decays into ${ }^{142} \mathrm{Nd}$ with a half-life of $T_{1 / 2}=68 \mathrm{Ma}$ (Kinoshita et al., 2012). Given this short half life, ${ }^{146} \mathrm{Sm}$ is effectively extinct by $\sim 4.0 \mathrm{Ga}$, therefore any deviation of the ${ }^{142} \mathrm{Nd}$ isotopic composition from the terrestrial standard has to be produced by fractionation between $\mathrm{Sm}$ and $\mathrm{Nd}$ that occurred prior to $4.0 \mathrm{Ga}$. The ${ }^{142} \mathrm{Nd}$ data set for the Nuvvuagittuq rocks has been expanded with 30 samples having a resolvable deficit in ${ }^{142} \mathrm{Nd}$ compared to the terrestrial standard. Most samples with low ${ }^{142} \mathrm{Nd} /{ }^{144} \mathrm{Nd}$ derive from the enriched low-Ti Ujaraaluk group. Within every group of Ujaraaluk, however, the ${ }^{142} \mathrm{Nd} /{ }^{144} \mathrm{Nd}$ ratios correlate with $\mathrm{Sm} / \mathrm{Nd}$ ratios. Any valid model for the origin of the Ujaraaluk unit needs to account for three main features regarding their ${ }^{142} \mathrm{Nd}$ isotopic composition. First, it must explain the deficit in ${ }^{142} \mathrm{Nd}$ relative to the terrestrial standard. Second, it must account for the $26 \mathrm{ppm}$ range in ${ }^{142} \mathrm{Nd}$ observed in the Ujaraaluk and cogenetic ultramafic sills. Third, it must explain the correlation between the Sm/Nd and ${ }^{142} \mathrm{Nd} /{ }^{144} \mathrm{Nd}$ ratios for all Ujaraaluk rocks and within each individual geochemical group. Here, we will discuss 3 possible models that could potentially explain the observed ${ }^{142} \mathrm{Nd}$ deficits: (1) Derivation of the NGB rocks in the Eoarchean from an enriched mantle formed in the Hadean, (2) Mixing in the Eoarchean with an Hadean enriched mantle reservoir and (3) Formation of the NGB rocks in the Hadean. We then will evaluate which model best accounts for the ${ }^{142} \mathrm{Nd}$ isotopic composition of the NGB rocks.

\subsubsection{Derivation from an Hadean enriched mantle}

Variability in ${ }^{142} \mathrm{Nd}$ in relatively young rocks can be inherited from mantle sources whose $\mathrm{Sm} / \mathrm{Nd}$ ratios were fractionated by differentiation events occurring prior to $4 \mathrm{Ga}$. A clear example is the presence of a wide range in initial ${ }^{142} \mathrm{Nd} /{ }^{144} \mathrm{Nd}$ in $<4 \mathrm{Ga}$ old lunar mare basalts (Rankenburg et al., 2006; Boyet and Carlson, 2007). Most terrestrial rocks have a $\sim 20$ ppm excess in ${ }^{142} \mathrm{Nd}$ compared to ordinary chondrites, which led Boyet and Carlson $(2005,2006)$ 


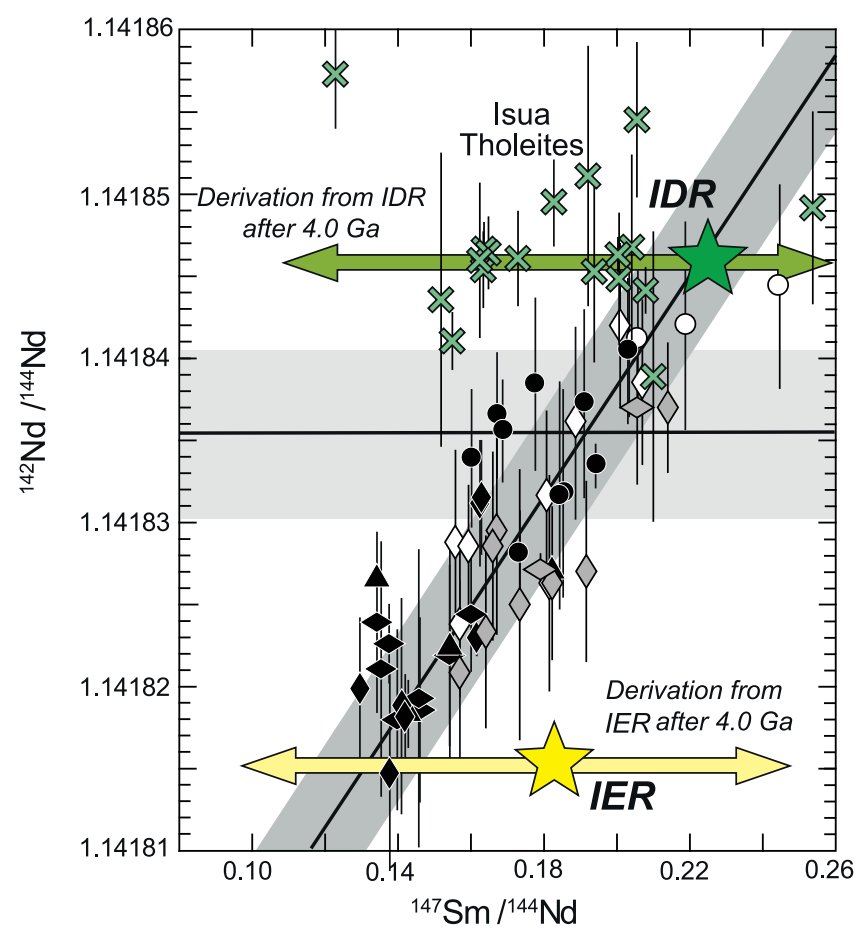

Fig. 7. ${ }^{147} \mathrm{Sm} /{ }^{144} \mathrm{Nd}$ vs. ${ }^{142} \mathrm{Nd} /{ }^{144} \mathrm{Nd}$ diagram. Symbols as in Fig. 2; green crosses, Isua samples from Rizo et al. (2011) and Bennett et al. (2007); green star, Isualike depleted reservoir (IDR) isotopic composition with a ${ }^{147} \mathrm{Sm} /{ }^{144} \mathrm{Nd}$ ratio $=0.225$ and a $\mu^{142} \mathrm{Nd}$ value of $\sim+9$ relative to terrestrial standard (Rizo et al., 2011; the ${ }^{147} \mathrm{Sm} /{ }^{144} \mathrm{Nd}$ ratio was re-calculated using the ${ }^{146} \mathrm{Sm}$ half-life of $68 \mathrm{Ma}$ ); yellow star, possible complementary Isua-like enriched reservoir (IER) with a $\mu^{142} \mathrm{Nd}$ value of $\sim-15 \mathrm{ppm}$ relative to terrestrial standard to account for the most negative NGB values and a ${ }^{147} \mathrm{Sm} /{ }^{144} \mathrm{Nd}$ ratio $=0.182$, required for an age of differentiation of $4.47 \mathrm{Ga}$ (Rizo et al., 2011). Horizontal black line shows the terrestrial standard value with $4.5 \mathrm{ppm}$ external error gray band. Oblique black line shows the best fit for the Ujaraaluk sample correlation with $4.5 \mathrm{ppm}$ external error being shown by the gray band. (For interpretation of the references to color in this figure legend, the reader is referred to the web version of the article.)

to propose that the Bulk Silicate Earth either has a superchondritic $\mathrm{Sm} / \mathrm{Nd}$ ratio or differentiated within $30 \mathrm{Ma}$ of planet formation to form an early depleted mantle. If the bulk Earth is chondritic in $\mathrm{Sm} / \mathrm{Nd}$ ratio, then the formation of an early depleted, i.e. high $\mathrm{Sm} / \mathrm{Nd}$ ratio, reservoir having an excess in ${ }^{142} \mathrm{Nd}$ must be coupled with the formation of an early enriched reservoir (EER) that is characterized by a complementary deficit in ${ }^{142} \mathrm{Nd}$ (Boyet and Carlson, 2006). Any rock derived from the EER will carry this deficit in ${ }^{142} \mathrm{Nd}$ independent of its age. Such rocks will not only have a deficit in ${ }^{142} \mathrm{Nd}$ relative to the terrestrial standard, but also relative to ordinary chondrite (i.e. $\sim-40 \mathrm{ppm}$ relative to the terrestrial standard). The NGB rocks have ${ }^{142} \mathrm{Nd}$ deficits up to $-18 \mathrm{ppm}$ relative to terrestrial standard and thus no deficit relative to ordinary chondrites. Therefore, the NGB rocks cannot be derived directly from the EER.

Positive anomalies in ${ }^{142} \mathrm{Nd}$ are found in amphibolites from Isua in SW Greenland. These $\sim 3.8 \mathrm{Ga}$ rocks have an excess in ${ }^{142} \mathrm{Nd}$ (up to $+19 \mathrm{ppm}$ ) compared to terrestrial standards (Rizo et al., 2011; Boyet and Carlson, 2006; Caro et al., 2003, 2006; Bennett et al., 2007). There is no correlation between the ${ }^{147} \mathrm{Sm} /{ }^{143} \mathrm{Nd}$ and the ${ }^{142} \mathrm{Nd} /{ }^{144} \mathrm{Nd}$ ratios in the Isua amphibolites (Fig. 7), consequently, the most likely origin of the excess ${ }^{142} \mathrm{Nd}$ in these rocks is that their mantle source was formed in the Hadean and was depleted in incompatible elements (i.e. high $\mathrm{Sm} / \mathrm{Nd}$ ratio) (Caro et al., 2006; Bennett et al., 2007; Rizo et al., 2011). This mantle reservoir was later sampled by an Eoarchean crust forming event that produced melts with variable $\mathrm{Sm} / \mathrm{Nd}$ ratio as a result of magmatic fractionation, but with ${ }^{142} \mathrm{Nd}$ excess inherited from the source. Because ${ }^{146} \mathrm{Sm}$ was extinct by $3.8 \mathrm{Ga}$, the rocks formed from these magmas will retain their initially uncorrelated $\mathrm{Sm} / \mathrm{Nd}$ and ${ }^{142} \mathrm{Nd} /{ }^{144} \mathrm{Nd}$ ratios to the present day. An Hadean complementary enriched reservoir to the Isua mantle source would have a deficit in ${ }^{142} \mathrm{Nd}$ relative to the terrestrial standard. Rocks derived from such an enriched reservoir during some later melting event would therefore yield negative anomalies in ${ }^{142} \mathrm{Nd}$ and thus could have similar isotopic compositions to the NGB rocks. However, partial fusion after $4.0 \mathrm{Ga}$ of an enriched mantle with a deficit in ${ }^{142} \mathrm{Nd}$ will produce magmas with deficits in ${ }^{142} \mathrm{Nd}$ that need not correlate with $\mathrm{Sm} / \mathrm{Nd}$ ratio, as shown by the analogous case of the Isua amphibolites (Fig. 7). In other words, all rocks derived from this source would have the same ${ }^{142} \mathrm{Nd}$ isotopic composition, regardless of their $\mathrm{Sm} / \mathrm{Nd}$ ratios. Direct post-4.0 Ga derivation from an enriched mantle reservoir formed contemporaneously with the Isua mantle source cannot account for the $26 \mathrm{ppm}$ variation in ${ }^{142} \mathrm{Nd}$ observed in the NGB rocks and more importantly, cannot explain the correlation between the $\mathrm{Sm} / \mathrm{Nd}$ and the ${ }^{142} \mathrm{Nd} /{ }^{144} \mathrm{Nd}$ ratios characteristic of the Ujaraaluk unit.

\subsubsection{Mixing of Hadean enriched and depleted mantle reservoirs}

There is always the possibility that a correlated array of $\mathrm{Nd}$ isotopic composition and $\mathrm{Sm} / \mathrm{Nd}$ ratio may represent a mixing line between 2 isotopically distinct reservoirs. The minimum age for the Ujaraaluk unit is constrained by the intrusion of the trondhjemitic bands dated at $3.8 \mathrm{Ga}$ (Cates and Mojzsis, 2007; David et al., 2009). The only way that the Ujaraaluk can have a deficit in ${ }^{142} \mathrm{Nd}$ if they indeed formed at $3.8 \mathrm{Ga}$, is to involve an Hadean enriched component in their petrogenesis. If the Ujaraaluk unit formed at 3.8 Ga from a "normal" depleted mantle (DM) source, mixing with an early enriched reservoir (EER) would induce a ${ }^{142} \mathrm{Nd}$ deficit and could yield a correlation between $\mathrm{Sm} / \mathrm{Nd}$ and ${ }^{142} \mathrm{Nd} /{ }^{144} \mathrm{Nd}$ if igneous fractionation did not greatly change the $\mathrm{Sm} / \mathrm{Nd}$ ratios of the mixed rocks (Fig. 8A). In this case, the correlation between the $\mathrm{Sm} / \mathrm{Nd}$ and the ${ }^{142} \mathrm{Nd} /{ }^{144} \mathrm{Nd}$ ratios would represent a mixing line without any age significance for the Ujaraaluk, at best providing only an approximate age for the time of separation of the EER and the DM. If the Ujaraaluk Sm/Nd vs. ${ }^{142} \mathrm{Nd}$ correlation is a mixing line, the ${ }^{147} \mathrm{Sm} /{ }^{144} \mathrm{Nd}$ ratio of the enriched reservoir must be less than $\sim 0.12$, and have a ${ }^{142} \mathrm{Nd}$ deficit of at least $\sim-20 \mathrm{ppm}$ relative to terrestrial standard (EER 1 in Fig. 8A). Given that mantle rocks with ${ }^{147} \mathrm{Sm} /{ }^{144} \mathrm{Nd}$ significantly less than 0.12 are uncommon [even the KREEP component of the Moon, a possible analog to an early terrestrial EER, has a ${ }^{147} \mathrm{Sm} /{ }^{144} \mathrm{Nd}$ of $\sim 0.168$ (Lugmair and Carlson, 1978)], the lowest Sm/Nd ratio end member in the Ujaraaluk would have to be dominated by the enriched end member. One could imagine that the early-formed enriched reservoir might be a strongly LREE enriched Hadean felsic crust, in which case the lowest $\mathrm{Sm} / \mathrm{Nd}$ ratio end member in the Ujaraaluk would still require more than a $50 \%$ by mass contribution from such "crustal contamination" if the mantle-derived end member were from "normal" terrestrial mantle. Given the basaltic major element composition of the low $\mathrm{Sm} / \mathrm{Nd}$ ratio end of the Ujaraaluk array, the compositional characteristics of the Ujaraaluk rocks do not support the possibility that this enriched mixing end member is Hadean felsic crust. Furthermore, if the ${ }^{142} \mathrm{Nd}$ deficits in the Ujaraaluk unit were produced by mixing with an Hadean LREE-enriched reservoir, a correlation between the $\mathrm{Nd}$ concentrations and the ${ }^{142} \mathrm{Nd}$ isotopic compositions at the time of mixing (presumably $3.8 \mathrm{Ga}$ ) would be expected. However, the $\mu^{142} \mathrm{Nd}$ values of the Nuvvuagittuq rocks show absolutely no correlation with their Nd concentrations for the entire set of data or within the individual Ujaraaluk geochemical groups (Fig. 8B). Moreover, if the ${ }^{142} \mathrm{Nd}$ deficits observed in most NGB lithologies, and the Sm/Nd vs. ${ }^{142} \mathrm{Nd} /{ }^{144} \mathrm{Nd}$ correlation, were produced by mixing between enriched and depleted mantle sources at $3.8 \mathrm{Ga}$, a positive correlation between $\mathrm{Sm} / \mathrm{Nd}$ ratio and initial ${ }^{143} \mathrm{Nd} /{ }^{144} \mathrm{Nd}_{(3.8 \mathrm{Ga})}$ would be expected that would give a 

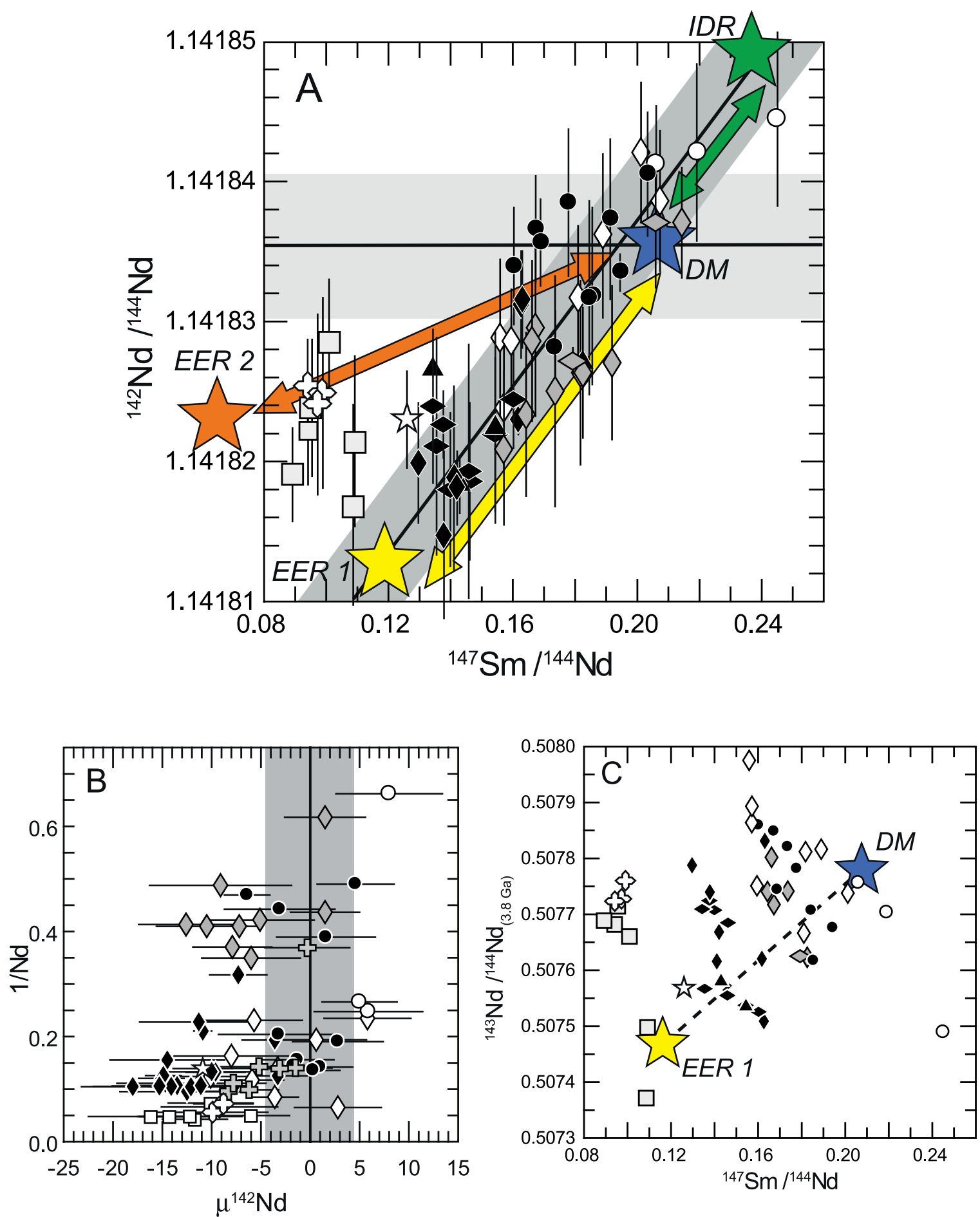

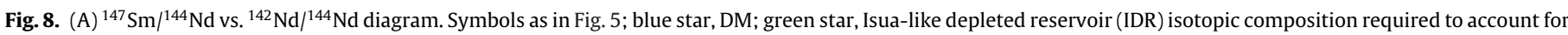

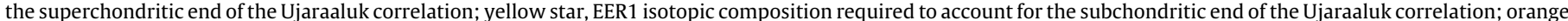

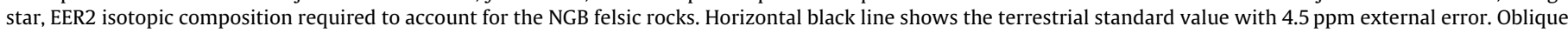

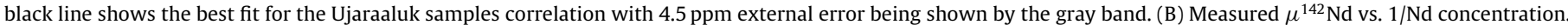

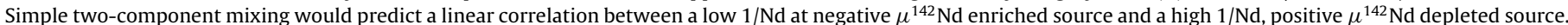

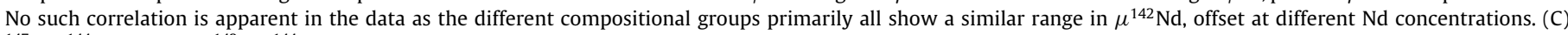

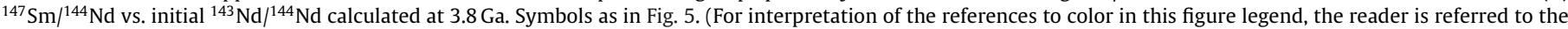
web version of the article.)

slope with an age somewhere between the time of the mixing event and the formation of the enriched and depleted mantle sources. This would also result in a $\mathrm{Sm} / \mathrm{Nd}$ vs. ${ }^{143} \mathrm{Nd} /{ }^{144} \mathrm{Nd}_{\text {(today) }}$ correlation producing a "fossil" isochron with an age older than $3.8 \mathrm{Ga}$. A ${ }^{147} \mathrm{Sm}-{ }^{143} \mathrm{Nd}$ isochron diagram constructed for the
Ujaraaluk samples using the ${ }^{143} \mathrm{Nd} /{ }^{144} \mathrm{Nd}$ ratios calculated at 3.8 Ga (Fig. 8C) displays mostly negative slopes within the individual chemical groups of Ujaraaluk, consistent with the $<3.8 \mathrm{Ga}$ ${ }^{147} \mathrm{Sm}-{ }^{143} \mathrm{Nd}$ isochron ages calculated for the different chemical groups. One could imagine a positive slope passing through the 
midpoints of the negative slopes of the individual chemical units shown in Fig. 8C that could be attributed to formation of the different chemical groups by mixing between Hadean depleted and enriched mantle sources. In this case, however, the negative correlations between the $\mathrm{Sm} / \mathrm{Nd}$ and ${ }^{143} \mathrm{Nd} /{ }^{144} \mathrm{Nd}_{(3.8 \mathrm{Ga})}$ ratios in the individual chemical groups would have to be attributed to substantial modification of $\mathrm{Sm} / \mathrm{Nd}$ ratios after $3.8 \mathrm{Ga}$. However, changes to $\mathrm{Sm} / \mathrm{Nd}$ ratio caused either by magmatic differentiation at $3.8 \mathrm{Ga}$, or by metamorphism after $3.8 \mathrm{Ga}$ would not be accompanied by changes in ${ }^{142} \mathrm{Nd} /{ }^{144} \mathrm{Nd}$ because ${ }^{146} \mathrm{Sm}$ was extinct by this time. Consequently, if the lack of a clear positive correlation between $\mathrm{Sm} / \mathrm{Nd}$ and ${ }^{143} \mathrm{Nd} /{ }^{144} \mathrm{Nd}_{(3.8 \mathrm{Ga})}$ is due to either magmatic or metamorphic modification of $\mathrm{Sm} / \mathrm{Nd}$ ratio at $3.8 \mathrm{Ga}$ or later, then a similar, or greater, degree of scatter should be observed in the $\mathrm{Sm} / \mathrm{Nd}$ vs. ${ }^{142} \mathrm{Nd} /{ }^{144} \mathrm{Nd}$ plot, yet this isochron diagram shows a good positive correlation for all Ujaraaluk samples and for each individual chemical group (see Fig. 10).

Although the possibility of mixing between Hadean enriched and depleted sources in the Archean to explain the NGB ${ }^{142} \mathrm{Nd}$ isotopic composition cannot completely be ruled out, another complication if all the NGB rocks formed in the Eoarchean is that the Eoarchean felsic rocks, including the only rocks unequivocally dated at $3.8 \mathrm{Ga}$ (i.e. the trondhjemitic bands), do not fall on the same Sm-Nd array defined by the Ujaraaluk samples (Fig. 8A). If the Ujaraaluk $\mathrm{Sm} / \mathrm{Nd}-{ }^{142} \mathrm{Nd}$ array reflects simple two-component mixing between enriched and depleted mantle sources at $3.8 \mathrm{Ga}$, then the offset of the felsic rocks from this line suggests a second enriched source (EER 2 in Fig. 8A) with much lower $\mathrm{Sm} / \mathrm{Nd}$ ratio at the same ${ }^{142} \mathrm{Nd} /{ }^{144} \mathrm{Nd}$ ratio compared to the enriched source involved in the Ujaraaluk correlation. Moreover, the $2.7 \mathrm{Ga}$ pegmatite would have to acquire its ${ }^{142} \mathrm{Nd}$ deficit by mixing with the same enriched source sampled by the Ujaraaluk (EER 1 in Fig. 8A), but over a billion years later, implying not only alternating sampling of different mixed sources (EER 1 and EER 2) in time but also the survival of these enriched reservoirs within the mantle for at least 1.5 billion years. Alternatively, the offset of the felsic rocks to lower $\mathrm{Sm} / \mathrm{Nd}$ ratio compared to the Ujaraaluk correlation could reflect the magmatic fractionation of $\mathrm{Sm} / \mathrm{Nd}$ ratio during the production and differentiation of these felsic rocks at various times post $3.8 \mathrm{Ga}$. If a similar magmatic fractionation of $\mathrm{Sm} / \mathrm{Nd}$ ratio in the Ujaraaluk occurred, as is suggested by the trace element characteristics of the Ujaraaluk (O'Neil et al., 2011a), then the preservation of a correlation between $\mathrm{Sm} / \mathrm{Nd}$ and ${ }^{142} \mathrm{Nd} /{ }^{144} \mathrm{Nd}$ ratio in a two-component mixture of enriched and depleted mantle sources is surprising if these rocks formed after ${ }^{146} \mathrm{Sm}$ became extinct. At the high $\mathrm{Sm} / \mathrm{Nd}$ ratio end of the Ujaraaluk correlation, the slight excess in ${ }^{142} \mathrm{Nd}$ observed in some NGB ultramafic rocks would require the involvement of an early Isua-like depleted reservoir to produce $\mu^{142} \mathrm{Nd}$ values as high as +8 (Fig. $8 \mathrm{~A}$ ). Therefore, a mixing model to account for the Sm-Nd systematics of all NGB lithologies would require at least 3 distinct sources including an early Isua-like depleted reservoir and 2 early enriched reservoirs. While such complicated mixing scenarios cannot be ruled out unequivocally, we consider them geologically unlikely.

All three Ujaraaluk geochemical groups follow the exact same $\mathrm{Sm} / \mathrm{Nd}$ vs. ${ }^{142} \mathrm{Nd} /{ }^{144} \mathrm{Nd}$ correlation (Fig. 10A). O'Neil et al. (2011a) showed that these Ujaraaluk groups have distinct major and trace element compositions suggesting that they were formed in different geological settings and derived from mantle sources with different geochemical compositions. The high-Ti Ujaraaluk unit is consistent with derivation from an undepleted mantle source and fractionation under relatively dry conditions, while both lowTi Ujaraaluk units appear to be derived from a mantle source that had experienced enrichment of highly incompatible elements followed by magmatic fractionation under elevated water pressures. Prior to the source incompatible element enrichment, the mantle source of the depleted low-Ti Ujaraaluk unit appears to have been a refractory mantle (e.g. subchondritic $\mathrm{Sm} / \mathrm{Yb}$ ratios) whereas the enriched low-Ti Ujaraaluk shows flat middle to heavy REE patterns consistent with an initially undepleted mantle source. Given that the three Ujaraaluk groups have distinct major and trace element compositions that imply they were produced from geochemically distinct mantle sources, fractionated under different conditions at low pressure, and possibly were produced in different geological settings, we consider it highly unlikely that the $\mathrm{Sm} / \mathrm{Nd}$ vs. ${ }^{142} \mathrm{Nd} /{ }^{144} \mathrm{Nd}$ correlation represents a mixing line where all three Ujaraaluk groups could have formed from the same isotopic end-members, producing a single correlation for the three compositionally distinct groups. Moreover, even a complex mixing history between depleted and enriched reservoirs cannot produce the isotopic relationship observed between the Ujaraaluk and their cogenetic ultramafic sills. As shown in O'Neil et al. (2011a), the sills share the same Al-Ti-Zr trends that define the 3 Ujaraaluk compositional groups with compositions controlled primarily by olivine fractionation (Fig. 9A). These compositional features suggest that the ultramafic rocks are cumulate bodies formed by the Ujaraaluk parental magmas. The magmatic accumulation of olivine, and possibly orthopyroxene, will produce cumulates with high $\mathrm{Sm} / \mathrm{Nd}$ ratios relative to the liquid. If the magmatic accumulation occurred after $4.0 \mathrm{Ga}$, the ultramafic cumulates would have high $\mathrm{Sm} / \mathrm{Nd}$ ratios, but retain the ${ }^{142} \mathrm{Nd} /{ }^{144} \mathrm{Nd}$ ratios of the Ujaraaluk parental magmas because ${ }^{146} \mathrm{Sm}$ is no longer extant to produce a change in ${ }^{142} \mathrm{Nd}$ abundance. High $\mathrm{Sm} / \mathrm{Nd}$ ratio cumulates produced after $4.0 \mathrm{Ga}$ would thus be expected to lie to the high $\mathrm{Sm} / \mathrm{Nd}$ ratio side of the Ujaraaluk Sm/Nd vs. ${ }^{142} \mathrm{Nd} /{ }^{144} \mathrm{Nd}$ array for the same reason that the felsic rocks lie to the low $\mathrm{Sm} / \mathrm{Nd}$ side of the array if they are partial melts or fractionated liquids from some parental rock/magma lying on the Ujaraaluk array. The same would be true if the ultramafic rocks are interpreted as restites from partial melting that produced the Ujaraaluk parental magmas. If this magma-restite relationship was established at $3.8 \mathrm{Ga}$, the Ujaraaluk ultramafic rocks would today be offset to high $\mathrm{Sm} / \mathrm{Nd}$ ratio from the $\mathrm{Sm} / \mathrm{Nd}-{ }^{142} \mathrm{Nd} /{ }^{144} \mathrm{Nd}$ correlation shown by the Ujaraaluk mafic rocks. If the ultramafic rocks formed before $4.0 \mathrm{Ga}$, however, while ${ }^{146} \mathrm{Sm}$ was still actively decaying, their high $\mathrm{Sm} / \mathrm{Nd}$ ratios would lead to high ${ }^{142} \mathrm{Nd} /{ }^{144} \mathrm{Nd}$ ratios compared to the Ujaraaluk magmas. The $\mathrm{Sm} / \mathrm{Nd}$ vs. ${ }^{142} \mathrm{Nd} /{ }^{144} \mathrm{Nd}$ correlation between the Ujaraaluk and their cogenetic ultramafic cumulates observed in each of the geochemical groups (Fig. 9B) can only be explained if the mineral fractionation forming the ultramafic cumulates occurred before $4.0 \mathrm{Ga}$. The isotopic relationship between the Ujaraaluk and their cogenetic ultramafic sills thus supports an Hadean formation age for the mafic/ultramafic rocks of the NGB.

\subsubsection{Formation of the NGB rocks in the Hadean}

In the simple case involving no metamorphic disturbance and no initial variation in the isotopic composition of the whole rocks, the correlation between $\mathrm{Sm} / \mathrm{Nd}$ and ${ }^{142} \mathrm{Nd} /{ }^{144} \mathrm{Nd}$ ratios in the Ujaraaluk would represent an isochron dating the time of the igneous event that formed these rocks. The Sm- ${ }^{142} \mathrm{Nd}$ isochron passes, within error, through the DM isotopic composition consistent with the derivation of the Ujaraaluk from "normal" depleted mantle and does not require the involvement of any "missing" enriched reservoirs or Isua-like depleted reservoirs. The decay of ${ }^{146} \mathrm{Sm}$ in rocks with $\mathrm{Sm} / \mathrm{Nd}$ ratios higher than the depleted mantle, primarily the cumulate ultramafic rocks, led to ${ }^{142} \mathrm{Nd} /{ }^{144} \mathrm{Nd}$ ratios higher than the modern depleted mantle whereas those with low $\mathrm{Sm} / \mathrm{Nd}$ ratio ended up with a deficit in ${ }^{142} \mathrm{Nd}$ compared to depleted mantle. While O'Neil et al. (2011a) interpreted the relationship of mafic to ultramafic Ujaraaluk rocks as parental magma to cumulate, the ultramafic rocks also could be proposed to represent the residues of the partial melting that produced the 

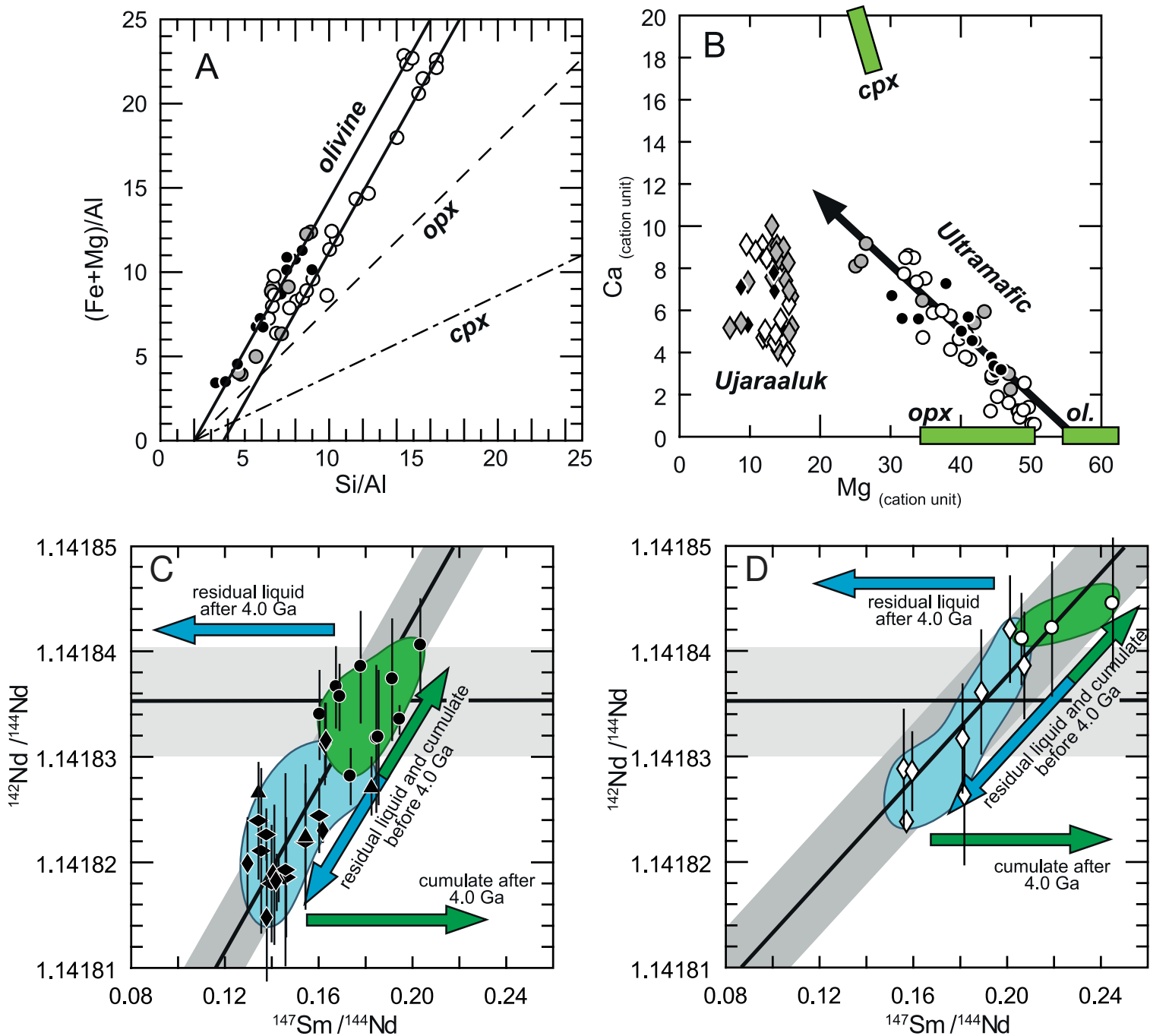

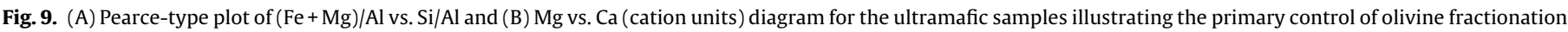

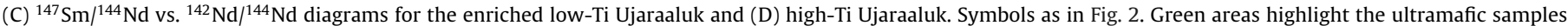

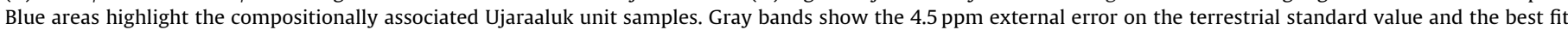
lines. (For interpretation of the references to color in this figure legend, the reader is referred to the web version of the article.)

mafic Ujaraaluk magmas. If this hypothetical relationship were established by melting at $3.8 \mathrm{Ga}$, both magma and restite would today have the same ${ }^{142} \mathrm{Nd} /{ }^{144} \mathrm{Nd}$ because there would be no ${ }^{146} \mathrm{Sm}$ extant to increase the ${ }^{142} \mathrm{Nd} /{ }^{144} \mathrm{Nd}$ ratios in the high $\mathrm{Sm} / \mathrm{Nd}$ ratio ultramafic rocks. There is no petrological or geochemical evidence supporting the idea that each of the Ujaraaluk groups is composed of a series of restites and melts. On the contrary, the major and trace element compositional variations of the mafic rocks from the three groups of Ujaraaluk are consistent with fractional crystallization from distinct parental magmas, whereas the composition of the ultramafic samples is consistent with them being cogenetic cumulates to the different mafic parental magmas (O'Neil et al., 2011a). Therefore, the compositional variations of the Ujaraaluk unit and the ultramafic rocks, as well as the Sm/Nd vs. ${ }^{142} \mathrm{Nd} /{ }^{144} \mathrm{Nd}$ ratio correlation are interpreted to be primary features acquired during the emplacement and crystallization of the Ujaraaluk unit.

The ${ }^{146} \mathrm{Sm}-{ }^{142} \mathrm{Nd}$ isochron for all Ujaraaluk samples and cogenetic sills corresponds to an age of $4388^{+15}{ }_{-17}$ Ma (Fig. 10A) with an initial $\mu^{142} \mathrm{Nd}$ value of $+4.7 \pm 2.0$ overlapping with the "normal" DM. Fitting all the Ujaraaluk mafic samples only, the isochron gives the same age of $4388^{+18}{ }_{-24} \mathrm{Ma}$. Isochrons fit individually to each of the different compositional groups in the Ujaraaluk (Fig. 10B-D) give ages of $4363^{+21}{ }_{-26} \mathrm{Ma}, 4374^{+26}{ }_{-35} \mathrm{Ma}$ and $4409^{+23}{ }_{-29}$ Ma for the high-Ti, depleted low-Ti, and enriched low-Ti groups respectively. Further support for an Hadean age for the Ujaraaluk unit is provided by the central intruding gabbro whose ${ }^{146} \mathrm{Sm}-{ }^{142} \mathrm{Nd}$ systematics yield an age of $4313^{+41}-69$ Ma (Fig. 10E). The Sm/Nd vs. ${ }^{142} \mathrm{Nd} /{ }^{144} \mathrm{Nd}$ correlation for the central gabbros is however not well-defined due to the limited spread in $\mathrm{Sm} / \mathrm{Nd}$ ratios and the consequent limited variation in ${ }^{142} \mathrm{Nd} /{ }^{144} \mathrm{Nd}$. Nevertheless, both the ${ }^{146} \mathrm{Sm}-{ }^{142} \mathrm{Nd}$ and ${ }^{147} \mathrm{Sm}-{ }^{143} \mathrm{Nd}$ systematics for the gabbros suggest an Hadean age of emplacement, providing a minimum age for Ujaraaluk unit. The ${ }^{146} \mathrm{Sm}-{ }^{142} \mathrm{Nd}$ isochron for these gabbros also passes through the DM with an initial $\mu^{142} \mathrm{Nd}$ value of $+0.1 \pm 3.1$.

\subsection{Consequences of metamorphic disturbance}

If the NGB rocks were not affected by later metamorphism, then the ${ }^{147} \mathrm{Sm}-{ }^{143} \mathrm{Nd}$ and ${ }^{146} \mathrm{Sm}-{ }^{142} \mathrm{Nd}$ data should provide concordant ages. The NGB has been extensively affected by metamorphism in the Neoarchean, however, as indicated by the numerous Sm-Nd ages on metamorphic minerals in the Ujaraaluk unit and intruding gabbro ranging between $2537 \mathrm{Ma}$ and $2735 \mathrm{Ma}$ (Fig. 4, Table SD6). These ages overlap the U-Pb zircon age of the intruding pegmatite, the $\mathrm{U}-\mathrm{Pb}$ ages obtained on metamorphic 

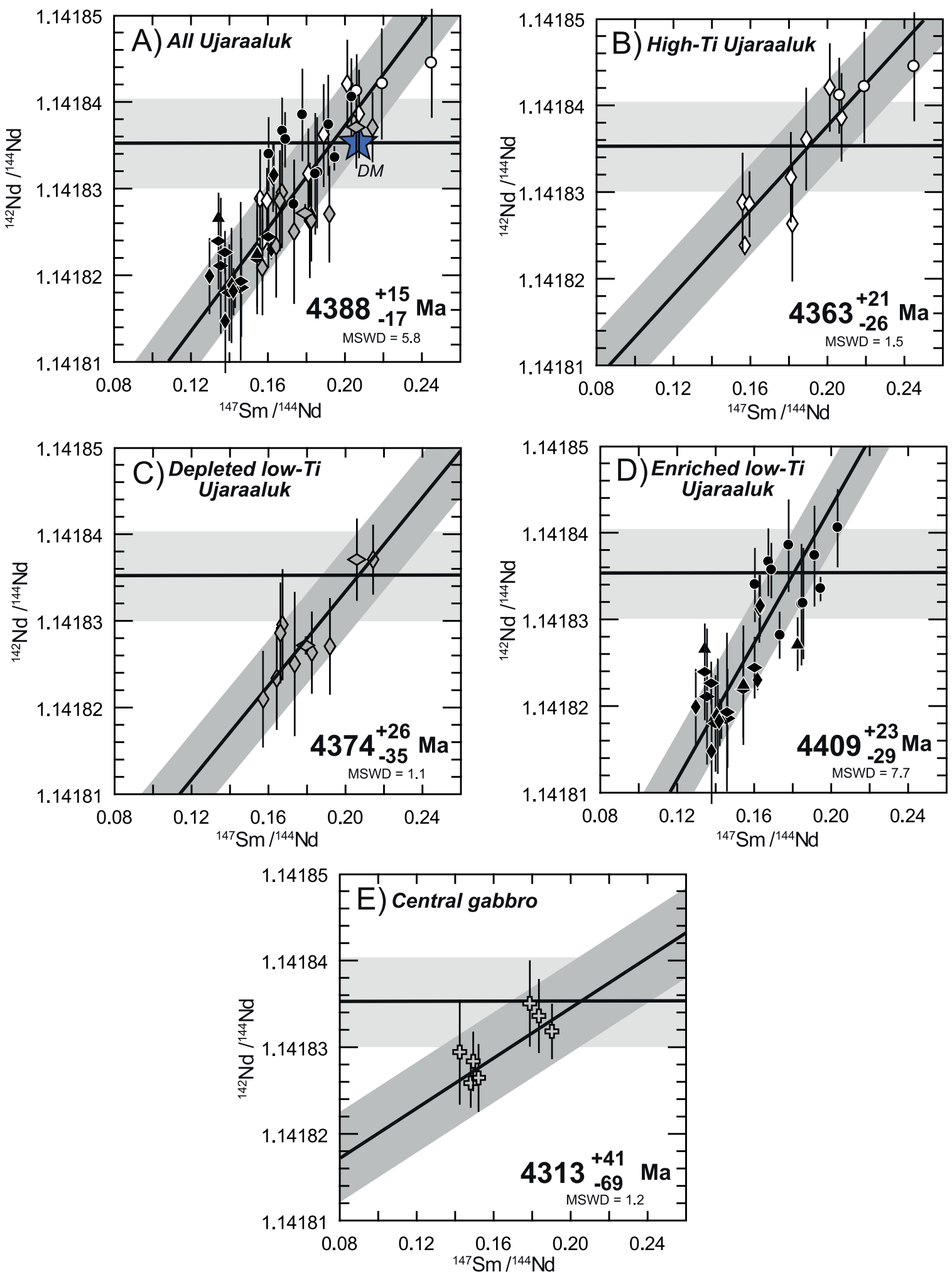

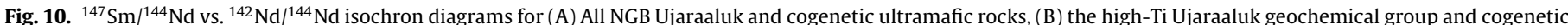

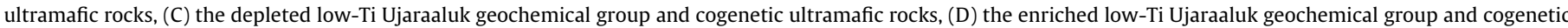

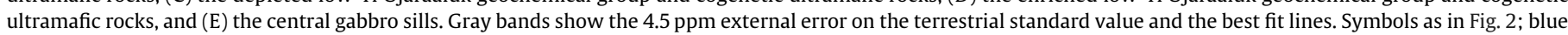
star, DM. (For interpretation of the references to color in this figure legend, the reader is referred to the web version of the article.)

zircon, rutile and monazite in the Ujaraaluk unit (O'Neil et al., 2011b; Darling et al., 2012) and the central gabbros (Fig. 6), as well as the $\mathrm{Pb}-\mathrm{Pb}$ age defined by whole rock samples of the Ujaraaluk (O'Neil et al., 2008). These results suggest that the peak of the metamorphism occurred at $\sim 2.7 \mathrm{Ga}$, contemporaneous with the emplacement of the Boizard suite (Simard et al., 2003) of heterogeneous tonalites surrounding the NGB supracrustal rocks and the 3.6 Ga NGB tonalite. Post-magmatic disturbance is also supported by younger Proterozoic Lu-Hf ages obtained in the same garnet dissolutions that provided Neoarchean Sm-Nd ages. 
The long-lived ${ }^{147} \mathrm{Sm}-{ }^{143} \mathrm{Nd}$ isotopic system can be affected by younger thermal events even at the whole rock scale. The data presented here show clearly that the ${ }^{147} \mathrm{Sm}-{ }^{143} \mathrm{Nd}$ system in the NBG samples has been affected by the Neoarchean metamorphism. The ${ }^{147} \mathrm{Sm}-{ }^{143} \mathrm{Nd}$ systematics for the different compositional groups of Ujaraaluk give ages between $3734 \mathrm{Ma}$ and $2517 \mathrm{Ma}$ with large errors, significant scatter, and a wide range of initial $\varepsilon \mathrm{Nd}$ values. The best example of this is the isochron for the enriched low-Ti Ujaraaluk that yields an age of $3734 \mathrm{Ma}$, but is clearly composed of 2 different groups of samples with 2 different slopes, both of which give Neoarchean ages (Fig. 2D). Small metamorphically induced changes to $\mathrm{Sm} / \mathrm{Nd}$ ratios at $2.7 \mathrm{Ga}$ will have significant effect on the evolution of ${ }^{143} \mathrm{Nd}$ as ${ }^{147} \mathrm{Sm}$ continues to decay to the present day. The same is not true for the ${ }^{146} \mathrm{Sm}-{ }^{142} \mathrm{Nd}$ system, however, because ${ }^{146} \mathrm{Sm}$ was long extinct by $2.7 \mathrm{Ga}$. Thus, late metamorphic changes to the Sm-Nd system will affect the ${ }^{147} \mathrm{Sm}-{ }^{143} \mathrm{Nd}$ and ${ }^{146} \mathrm{Sm}-{ }^{142} \mathrm{Nd}$ results differently. The only way to change the ${ }^{142} \mathrm{Nd} /{ }^{144} \mathrm{Nd}$ ratio after ${ }^{146} \mathrm{Sm}$ has become extinct is to involve mixing with a fluid/melt having a different ${ }^{142} \mathrm{Nd}$ isotopic composition. Changes in $\mathrm{Sm} / \mathrm{Nd}$ ratio after ${ }^{146} \mathrm{Sm}$ is gone will not affect the ${ }^{142} \mathrm{Nd}$ isotopic composition, but will affect the slope of a Sm/Nd vs. ${ }^{142} \mathrm{Nd} /{ }^{144} \mathrm{Nd}$ correlation, which we show below will have only minimal affect on the ${ }^{146} \mathrm{Sm}-{ }^{142} \mathrm{Nd}$ age obtained.

Fig. 11 shows the effects of a complex metamorphic history on the ${ }^{147} \mathrm{Sm}-{ }^{143} \mathrm{Nd}$ system and the robustness of the ${ }^{146} \mathrm{Sm}-{ }^{142} \mathrm{Nd}$ system. Here we model two scenarios for a $2.7 \mathrm{Ga}$ disturbance in 4.4 Ga rocks and examine the relative effects on both long-lived and short-lived Sm-Nd isotopic systems. The circles in Fig. 11 represent two undisturbed $4.4 \mathrm{Ga}$ Ujaraaluk rocks, a low $\mathrm{Sm} / \mathrm{Nd}$ rock (U1, U2, U3) and a high Sm/Nd rock (U4, U5, U6), at three different times, from $t=0$, or $4.4 \mathrm{Ga}$ ago (U1 and U4) to today (U3 and U6). In the first scenario (Fig. 11A), at $2.7 \mathrm{Ga}$ (or $1.7 \mathrm{Ga}$ after $t=0$ ), the undisturbed rocks (U2 and U5) are affected by a thermal event and partial melting, producing the $\sim 2.7$ Ga pegmatites (yellow stars). The analyzed pegmatite sample has a deficit in ${ }^{142} \mathrm{Nd}$ despite the fact that it was produced after $4.0 \mathrm{Ga}$. Thus the most likely source of the pegmatites is a rock that already contained a ${ }^{142} \mathrm{Nd}$ deficit, such as the Ujaraaluk unit. Melting of the Ujaraaluk unit at $2.7 \mathrm{Ga}$ produces restites with higher Sm/Nd ratios (R1 and R3) and mixing between the pegmatitic liquid and the Ujaraaluk also produces rocks with lower $\mathrm{Sm} / \mathrm{Nd}$ ratios (M1 and M3). In this case, the two hypothetical Ujaraaluk starting samples are subjected to the same melting scenario and produce their own pegmatitic liquids having the same isotopic composition as their respective parent rocks at the time of melting. The restites and mixed rocks evolve to give ${ }^{147} \mathrm{Sm}-{ }^{143} \mathrm{Nd}$ isochron ages of $2.7 \mathrm{Ga}$ (M2-U3-R2 and M4-U6-R4). Sm/Nd ratios for the restites were calculated using batch melting equations. The composition of the pegmatite (sample R18) was used as the liquid composition whereas the composition of Ujaraaluk sample PC-129 was used as the original unmelted composition of the low $\mathrm{Sm} / \mathrm{Nd}$ rock (U2) as it falls close to the ${ }^{142} \mathrm{Nd}$ isochron in Fig. $10 \mathrm{~A}$ and has the same ${ }^{142} \mathrm{Nd} /{ }^{144} \mathrm{Nd}$ ratio as the pegmatite. The variation in $\mathrm{Sm} / \mathrm{Nd}$ ratio obtained for the low $\mathrm{Sm} / \mathrm{Nd}$ restite (R1) was used to calculate the $\mathrm{Sm} / \mathrm{Nd}$ ratio of the high $\mathrm{Sm} / \mathrm{Nd}$ restite (R3). If the restites are produced from $15 \%$ melt extraction of both Ujaraaluk rocks, and the mixed rocks are formed from $30 \%$ mixing with the pegmatite, this would translate today to a $5 \%$ increase in $\mathrm{Sm} / \mathrm{Nd}$ for the restite (U6-R4) and 6\% decrease in Sm/Nd for the mixed rock (U3-M2). Increasing the $\mathrm{Sm} / \mathrm{Nd}$ ratio of the high $\mathrm{Sm} / \mathrm{Nd}$ rocks while decreasing the $\mathrm{Sm} / \mathrm{Nd}$ ratio of the low $\mathrm{Sm} / \mathrm{Nd}$ rock will have the largest effect on the ${ }^{142} \mathrm{Nd}$ isochron age. However, the age of the ${ }^{142} \mathrm{Nd}$ isochron only decreases from $4.4 \mathrm{Ga}$ to $4.37 \mathrm{Ga}$ (M2-R4 in Fig. 11C). Different degrees of melting lead to different $\mathrm{Sm} / \mathrm{Nd}$ ratios but the effect on the ${ }^{142} \mathrm{Nd}$ isochron remains small. Using $5 \%$ and $25 \%$ melting for the low $\mathrm{Sm} / \mathrm{Nd}$ rock (R5) and the high $\mathrm{Sm} / \mathrm{Nd}$ rock (R7)
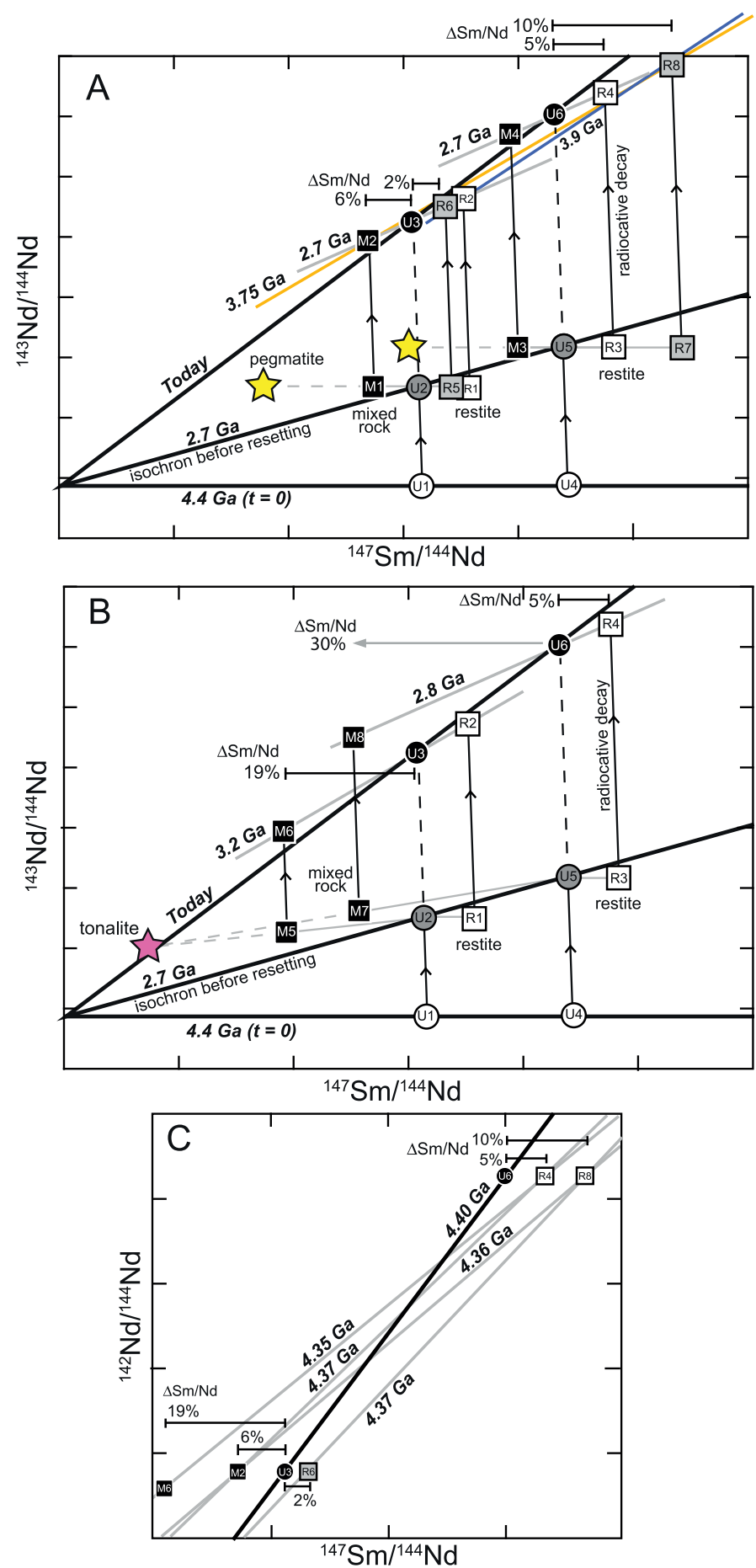

Fig. 11. (A) ${ }^{147} \mathrm{Sm} /{ }^{144} \mathrm{Nd}$ vs. ${ }^{143} \mathrm{Nd} /{ }^{144} \mathrm{Nd}$ diagram showing the effect of a $2.7 \mathrm{Ga}$ isotopic disturbance after partial melting of the Ujaraaluk unit and mixing with a pegmatitic liquid. (B) ${ }^{147} \mathrm{Sm} /{ }^{144} \mathrm{Nd}$ vs. ${ }^{143} \mathrm{Nd} /{ }^{144} \mathrm{Nd}$ diagram showing the effect of a $2.7 \mathrm{Ga}$ isotopic disturbance after partial melting of the Ujaraaluk unit and mixing with a $3.66 \mathrm{Ga}$ tonalitic liquid. (C) ${ }^{147} \mathrm{Sm} /{ }^{144} \mathrm{Nd}$ vs. ${ }^{142} \mathrm{Nd} /{ }^{144} \mathrm{Nd}$ diagram showing the effect of the different $\mathrm{Sm} / \mathrm{Nd}$ variations illustrated in (A) and (B) on the short-lived isotopic system. Symbols: circles, undisturbed Ujaraaluk; R1-R8 squares, restites; M1-M8 squares, mixed rocks, yellow star, pegmatitic liquid; pink star, tonalitic liquid. (For interpretation of the references to color in this figure legend, the reader is referred to the web version of the article.)

respectively, the ${ }^{143} \mathrm{Nd}$ isochron for the restites yields an age of 3.9 Ga (R6-R8), while the ${ }^{142} \mathrm{Nd}$ isochron age is lowered to $4.37 \mathrm{Ga}$. A ${ }^{143} \mathrm{Nd}$ isochron passing through the high $\mathrm{Sm} / \mathrm{Nd}$ restite and the low $\mathrm{Sm} / \mathrm{Nd}$ mix rock (M2-R8) gives an age of $3.75 \mathrm{Ga}$, while the ${ }^{142} \mathrm{Nd}$ age decreases to $4.36 \mathrm{Ga}$. 
The second scenario (Fig. 11B) involves partial melting of the Ujaraaluk at $2.7 \mathrm{Ga}$ producing the same restites as in Fig. $11 \mathrm{~A}$ (R1, R3) but the mixed rocks are formed by mixing between the undisturbed rocks and an enriched tonalite (M5, M7). The tonalite isotopic composition used for the model is in the middle of the range of isotopic compositions measured for the Nuvvuagittuq tonalities. This tonalite has a deficit in ${ }^{142} \mathrm{Nd}$ and therefore will also affect the ${ }^{142} \mathrm{Nd}$ isotopic composition of the mixed rock. A mixture with $30 \%$ tonalitic melt produces ${ }^{143} \mathrm{Nd}$ isochrons ranging from $2.8 \mathrm{Ga}$ to $3.4 \mathrm{Ga}$ while the age of the ${ }^{142} \mathrm{Nd}$ isochron goes from $4.4 \mathrm{Ga}$ to $4.36 \mathrm{Ga}$. The ${ }^{142} \mathrm{Nd}$ isochron is calculated using the high $\mathrm{Sm} / \mathrm{Nd}$ restite and the low $\mathrm{Sm} / \mathrm{Nd}$ mix rock (M6-R4) in order to lower the slope of the isochron. Mixing involving more tonalite will have a more important effect on the ages. A mixture with $50 \%$ tonalite (Fig. 11B) produces ${ }^{143} \mathrm{Nd}$ isochrons ranging from $3.2 \mathrm{Ga}$ (M6-U3-R2) to $2.8 \mathrm{Ga}$ (M8-U6-R4). This degree of mixing with a tonalite would result in a composition that deviates substantially from the mafic compositions of the Ujaraaluk rocks. Even this high extent of tonalite "contamination", however, only lowers the ${ }^{142} \mathrm{Nd}$ isochron age to $4.35 \mathrm{Ga}$ (M6-R4 in Fig. 11C). Although there is little evidence that the $3.6 \mathrm{Ga}$ tonalite mixed with the Ujaraaluk at $2.7 \mathrm{Ga}$, the Ujaraaluk is enclosed by the tonalite at the time of the peak metamorphism and the tonalite represents an obvious potential contaminant. Despite the fact that this tonalitic contaminant would significantly disturb the ${ }^{147} \mathrm{Sm}-{ }^{143} \mathrm{Nd}$ systematics of the Ujaraaluk rocks, the ${ }^{142} \mathrm{Nd}$ ages are relatively unaffected, reinforcing the robustness of the short-lived isotopic system even if the long-lived system is partially reset.

A few Nuvvuagittuq samples show evidence of strong isotopic disturbance consistent with the most extreme cases illustrated in Fig. 11. Two high-Ti Ujaraaluk (PC-058, PC-451) and one depleted low-Ti Ujaraaluk (PC-214) samples lie well off of the $\mathrm{Sm} / \mathrm{Nd}$ vs. ${ }^{142} \mathrm{Nd} /{ }^{144} \mathrm{Nd}$ correlations defined by the remaining samples. These samples are interpreted as being strongly disturbed. Samples PC058 and PC-451 exhibit LREE-enriched profiles strikingly different from the rest of the high-Ti Ujaraaluk samples (Fig. 12A). They also have higher Nd concentrations consistent with them being affected by LREE-enriched fluids during post-magmatic alteration or metamorphism. Both PC-058 and PC-451 fall to the low Sm/Nd side of the ${ }^{146} \mathrm{Sm}-{ }^{142} \mathrm{Nd}$ isochron (Fig. 12A). Though their Sm/Nd ratios are lower than other high-Ti Ujaraaluk samples, their ${ }^{142} \mathrm{Nd}$ isotopic compositions are similar to the least affected high-Ti Ujaraaluk samples with flat REE profiles. Ujaraaluk sample PC-058 exhibits the most extreme offset from the $\mathrm{Sm} / \mathrm{Nd}-{ }^{142} \mathrm{Nd}$ correlation defined by the majority of the Ujaraaluk samples. The composition of this sample can be reproduced by a disturbance similar to the scenario involving 50\% mixing with a tonalitic melt (Fig. 11B). Its strong LREE-enriched profile can be reproduced by $50 \%$ mixing of an undisturbed high-Ti Ujaraaluk and a Nuvvuagittuq tonalite (Fig. 12B). A $50 \%$ mixture of a high $\mathrm{Sm} / \mathrm{Nd}$ rock and a tonalite produces a $30 \%$ change in $\mathrm{Sm} / \mathrm{Nd}$ (U6-M8), consistent with the difference in $\mathrm{Sm} / \mathrm{Nd}$ between PC-058 and an undisturbed sample falling on the ${ }^{142} \mathrm{Nd}$ isochron (35\% variation; Fig. 11B). PC-214 is offset to the high $\mathrm{Sm} / \mathrm{Nd}$ side of the main Ujaraaluk $\mathrm{Sm} / \mathrm{Nd}-{ }^{142} \mathrm{Nd}$ correlation (Fig. 12A). This sample is an orthopyroxene-rich layer within an ultramafic sill (cogenentic with the depleted low-Ti Ujaraaluk) that exhibits a metamorphic texture with $\sim 120^{\circ}$ grain boundaries and has a strongly depleted REE profile (Fig. 12A). Formation of a metamorphic orthopyroxenite after $4 \mathrm{Ga}$ will increase the $\mathrm{Sm} / \mathrm{Nd}$ ratio without affecting the ${ }^{142} \mathrm{Nd} /{ }^{144} \mathrm{Nd}$ ratio. Fig. 12A shows that this sample has been horizontally shifted to the high $\mathrm{Sm} / \mathrm{Nd}$ side of the Ujaraaluk array with a ${ }^{142} \mathrm{Nd}$ isotopic composition that remained in the same range as the other ultramafic sill values. A ${ }^{147} \mathrm{Sm}-{ }^{143} \mathrm{Nd}$ isochron including ultramafic samples, PC-214 and other pyroxene layers within the same sill yields an age of $2763 \mathrm{Ma}$ (Fig. SD5) supporting the fact that the orthopyroxene layers were formed
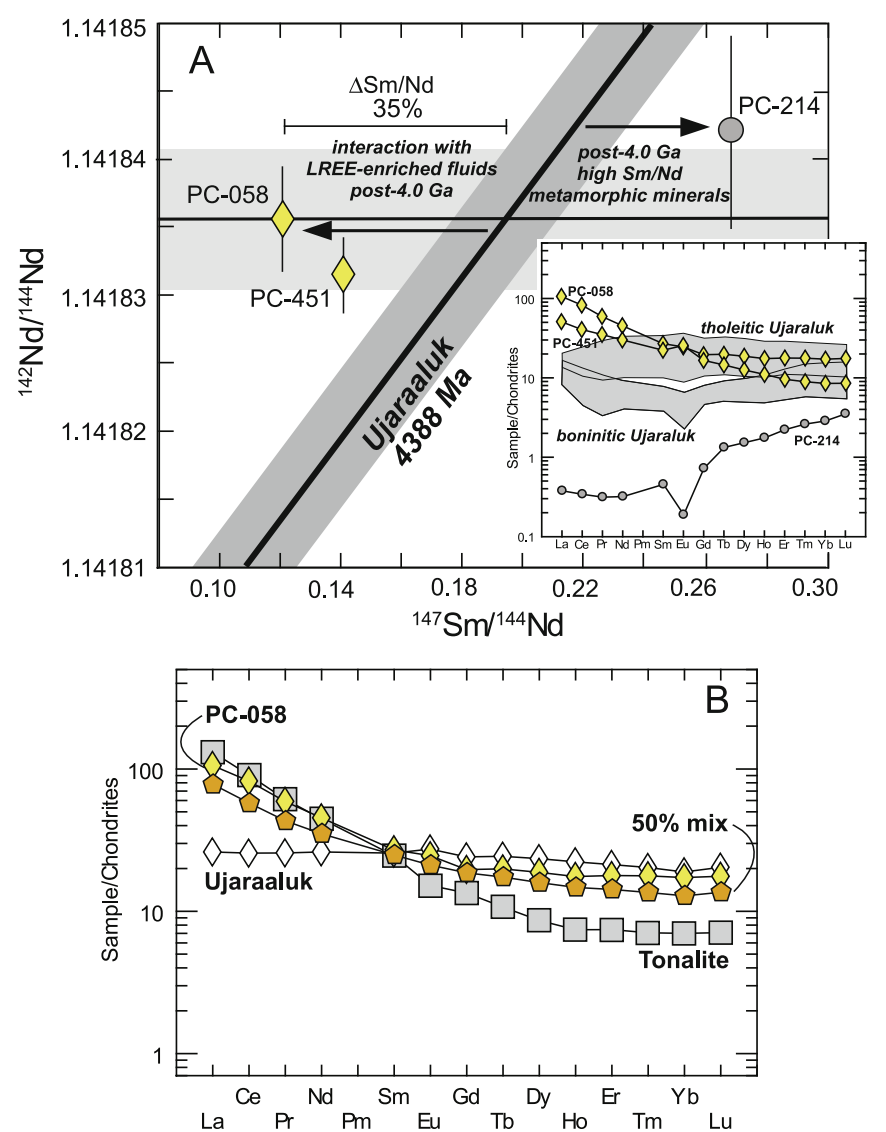

Fig. 12. (A) ${ }^{147} \mathrm{Sm} /{ }^{144} \mathrm{Nd}$ vs. ${ }^{142} \mathrm{Nd} /{ }^{144} \mathrm{Nd}$ diagram showing the effect of post- $4.0 \mathrm{Ga}$ disturbances on some NGB samples. Oblique black line shows the best fit line of Fig. 10A. Gray bands show the $4.5 \mathrm{ppm}$ external error on the terrestrial standard value and the best fit line. Inserted diagram shows the REE profiles of the most disturbed Ujaraaluk samples compared to their respective geochemical groups. (B) REE profiles for a Ujaraaluk sample, a tonalite sample, PC-058 (most disturbed sample) along with the composition of $50 \%$ mix between the Ujaraaluk and the tonalite. Chondritic normalization values are from Sun and McDonough (1989).

during the Neoarchean metamorphism. These three strongly disturbed samples (PC-058, PC-451 and PC-214) fall significantly off their respective ${ }^{147} \mathrm{Sm} /{ }^{143} \mathrm{Nd}$ and ${ }^{146} \mathrm{Sm}-{ }^{142} \mathrm{Nd}$ isochrons and have been considered as outliers and excluded from both the ${ }^{143} \mathrm{Nd}$ and ${ }^{142} \mathrm{Nd}$ age calculations.

In summary, although metamorphism has disturbed the longlived ${ }^{147} \mathrm{Sm}-{ }^{143} \mathrm{Nd}$ isotopic system in the Ujaraaluk, the effects on the short-lived ${ }^{146} \mathrm{Sm}-{ }^{142} \mathrm{Nd}$ system are not significant. In contrast, the central gabbro sills yield ${ }^{143} \mathrm{Nd}$ and ${ }^{142} \mathrm{Nd}$ isochrons with Hadean ages between 4.1 and $4.3 \mathrm{Ga}$, suggesting that the ${ }^{143} \mathrm{Nd}$ isotopic system has not been reset to the same extent in the gabbro sills as it has in the Ujaraaluk unit. This may reflect their different lithology. The Ujaraaluk unit is interpreted to be a hydrothermally altered pyroclastic volcanic deposit (O'Neil et al., 2011a), whereas the gabbro sills are massive intrusions that are perhaps more resistant to disturbance by metamorphic fluids/melts. The magnitude of metamorphic disturbance that would turn $4.4 \mathrm{Ga}$ ${ }^{147} \mathrm{Sm}-{ }^{143} \mathrm{Nd}$ ages into the scatter of younger, $3.8-2.7 \mathrm{Ga}$, ages seen in the various compositional groups of the Ujaraaluk would reduce the ${ }^{146} \mathrm{Sm}-{ }^{142} \mathrm{Nd}$ ages by only of order $50 \mathrm{Ma}$ or less. Thus, while there is no escaping the conclusion that Archean metamorphism has disturbed the Sm-Nd geochronometer in the Ujaraaluk rocks, the discordance between the ${ }^{147} \mathrm{Sm}-{ }^{143} \mathrm{Nd}$ and ${ }^{146} \mathrm{Sm}-{ }^{142} \mathrm{Nd}$ results does not necessarily imply that the ${ }^{146} \mathrm{Sm}-{ }^{142} \mathrm{Nd}$ ages are significantly inaccurate. In fact, in our opinion, the types of metamorphic disturbance modeled in Fig. 11 provide a simpler and more 
geologically plausible explanation to the discordant ${ }^{147} \mathrm{Sm}-{ }^{143} \mathrm{Nd}$ and ${ }^{146} \mathrm{Sm}-{ }^{142} \mathrm{Nd}$ ages than do the complicated source mixing models considered in Section 5.1.2. We suggest that the discordance between ${ }^{143} \mathrm{Nd}$ and ${ }^{142} \mathrm{Nd}$ ages provides additional support for our conclusion that the Ujaraaluk rocks formed by partial melting of "normal" depleted mantle in the Hadean, rather than by Eoarchean melting of multiple Hadean mantle sources followed by some complicated mixing/fractionation scenario that would obliterate the Hadean ages from the ${ }^{147} \mathrm{Sm}-{ }^{143} \mathrm{Nd}$ system, but preserve them in ${ }^{146} \mathrm{Sm}-{ }^{142} \mathrm{Nd}$.

\subsection{Origin of the NGB felsic rocks}

The Nuvvuagittuq felsic rocks include the $3.8 \mathrm{Ga}$ trondhjemitic bands, the 3.6 Ga tonalites and the $2.7 \mathrm{Ga}$ pegmatites, all Archean in age. Despite the fact that they formed after the extinction of ${ }^{146} \mathrm{Sm}$, most Nuvvuagittuq felsic rocks have a resolvable deficit in ${ }^{142} \mathrm{Nd}$ (Fig. 5). Negative ${ }^{142} \mathrm{Nd}$ anomalies in Archean rocks indicate that their precursor had a deficit in ${ }^{142} \mathrm{Nd}$ at the time of their formation. The obvious candidates for precursors for the Nuvvuagittuq felsic rocks are the mafic basement rocks of the Ujaraaluk unit. Adam et al. (2011) conducted melting experiments on samples of the Ujaraaluk unit and obtained partial melts that match the compositions of the Nuvvuagittuq tonalites. In the field, enclaves a few meters wide by tens of meters long of mafic amphibolites are observed within the tonalite. The size and number of these mafic enclaves in the tonalite increase as the contact between the tonalite and the Nuvvuagittuq belt is approached and seams of tonalite occur in the mafic lithologies adjacent to the tonalite contact.

All Nuvvuagittuq felsic rocks plot to the low $\mathrm{Sm} / \mathrm{Nd}$ ratio side of the ${ }^{142} \mathrm{Nd}$ isochron defined by the Ujaraaluk. Partial melting in the Archean of any mafic Ujaraaluk composition will produce a felsic magma with a lower Sm/Nd ratio but with the same ${ }^{142} \mathrm{Nd} /{ }^{144} \mathrm{Nd}$ ratio as their parent rock. The Nuvvuagittuq tonalities yield $\mu^{142} \mathrm{Nd}$ values ranging from -6 to $-16 \mathrm{ppm}$ with no correlation between their $\mathrm{Sm} / \mathrm{Nd}$ and ${ }^{142} \mathrm{Nd} /{ }^{144} \mathrm{Nd}$ ratios (Fig. 13) consistent with their derivation from the melting of the mafic Ujaraaluk unit post$4.0 \mathrm{Ga}$. The Ujaraaluk unit exhibits a wide range of ${ }^{142} \mathrm{Nd}$ isotopic

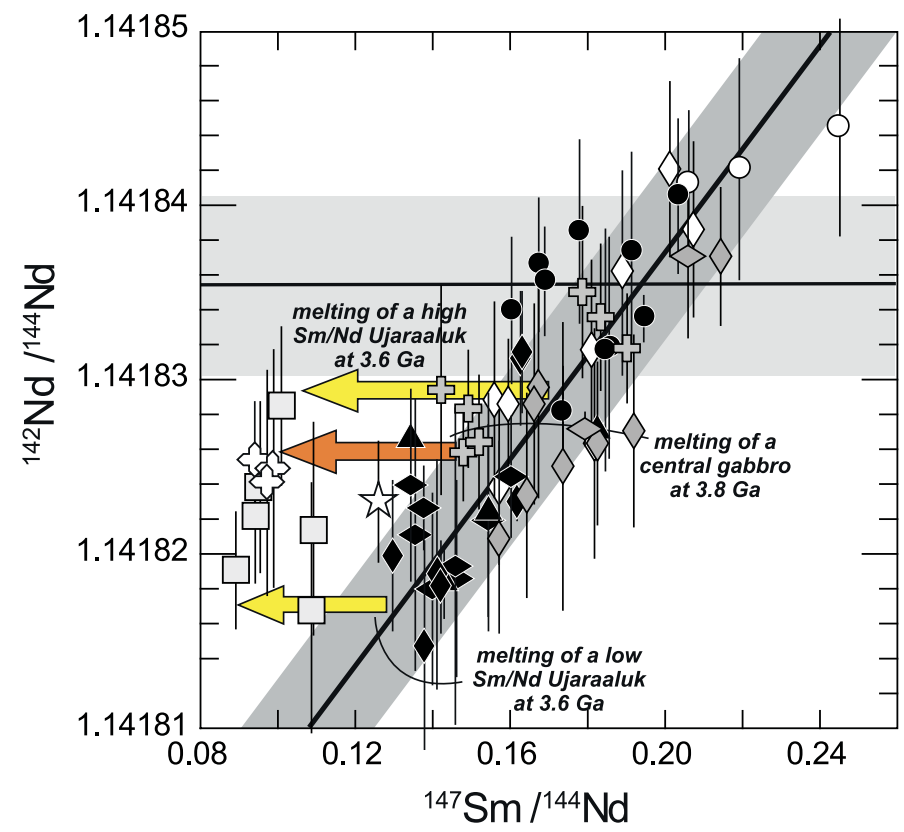

Fig. 13. ${ }^{147} \mathrm{Sm} /{ }^{144} \mathrm{Nd}$ vs. ${ }^{142} \mathrm{Nd} /{ }^{144} \mathrm{Nd}$ diagram showing the effect of post- $4.0 \mathrm{Ga}$ partial melting of mafic Ujaraaluk to produce the NGB felsic rocks. Gray bands show the 4.5 ppm external error on the terrestrial standard value and the best fit line. Symbols as in Fig. 5. compositions, thus partial melting of Ujaraaluk rocks would produce tonalites spanning the same range in ${ }^{142} \mathrm{Nd} /{ }^{144} \mathrm{Nd}$, but with lower $\mathrm{Sm} / \mathrm{Nd}$ ratios which causes the tonalites to be displaced to the left of the Ujaraaluk ${ }^{146} \mathrm{Sm}-{ }^{142} \mathrm{Nd}$ isochron. Moreover, a ${ }^{147} \mathrm{Sm}-{ }^{143} \mathrm{Nd}$ isochron for the tonalities yields an age of $3575 \mathrm{Ma}$, consistent with their $\mathrm{U}-\mathrm{Pb}$ age, but with an initial $\varepsilon \mathrm{Nd}$ value of -2.9 . This negative $\varepsilon \mathrm{Nd}$ value at $3575 \mathrm{Ma}$ indicates a much older, low $\mathrm{Sm} / \mathrm{Nd}$ ratio, precursor for the tonalite. In fact, the initial ${ }^{143} \mathrm{Nd}$ isotopic composition for the tonalites falls on the isotopic evolution line of a $4.4 \mathrm{Ga}$ mantle-derived mafic precursor (Fig. 14) having an isotopic composition consistent with the Ujaraaluk unit. An Hadean source rock for the tonalites is further supported by their $T_{\mathrm{DM}}$ values ranging from $3.8 \mathrm{Ga}$ to $4.4 \mathrm{Ga}$. The trondjhemitic bands and the pegmatites also have deficits in ${ }^{142} \mathrm{Nd}$ with $T_{\mathrm{DM}}$ values ranging from 3.8 Ga to $4.2 \mathrm{Ga}$. These felsic rocks fall on the low $\mathrm{Sm} / \mathrm{Nd}$ ratio side of the Ujaraaluk ${ }^{146} \mathrm{Sm}-{ }^{142} \mathrm{Nd}$ isochron (Fig. 13) suggesting that they also may have been formed by the partial melting of the Ujaraaluk unit or the central gabbros during later events.

\subsection{Other Eoarchean components in the NGB}

Beside the trondhjemetic bands and the tonalites, zircons from rocks interpreted to be detrital sediments by some authors (David et al., 2009; Cates et al., 2011; Darling et al., 2012) have yielded Eoarchean $\mathrm{U}-\mathrm{Pb}$ ages. These rocks include quartzites with $3.78 \mathrm{Ga}$ zircons (Cates et al., 2011), putative conglomerates with distinct zircon populations with ages of $3.78 \mathrm{Ga}, 3.66 \mathrm{Ga}, 3.36 \mathrm{Ga}$ and $\sim 2.7 \mathrm{Ga}$ (David et al., 2009) and rocks interpreted to be quartzalbite-clinozoisite metasediments with concordant zircon ages ranging from 3630 to $3680 \mathrm{Ma}$. The NGB, however, has been subjected to a complex thermal history and extensive metasomatism sometimes accompanied by the formation of younger metamorphic/metasomatic zircon as seen in the central gabbro (Fig. 6). Understanding the exact geological context of a given lithology, its position in the NGB stratigraphy, and the origins of the zircons it contains thus is critical to the correct interpretation of the zircon age constraints. The detrital origin of the quartz-rich rocks in the NGB is difficult to conclusively demonstrate due to their intensive deformation and recrystallization. The conglomeratic units consist of $0.5-2 \mathrm{~m}$ thick horizons containing rounded quartz clasts in a biotite-bearing matrix. The quartz grains in the clasts have ${ }^{18} \mathrm{O}$-enriched compositions and the trace sulfides in the clasts yield significant mass-independent $S$ isotope fractionation consistent with a sedimentary origin for the quartz and sulfide grains (Kitayama et al., 2011). ${ }^{18}$ O-enriched compositions and mass-independent $\mathrm{S}$ isotope fractionation only suggest a sedimentary origin for the quartz and sulfide grains contained in the conglomeratic unit, but do not require a detrital origin for of the host rock. On the other hand, the homogeneity in clast composition is consistent with a single local source, most likely the prominent silica-formation described in O'Neil et al. (2007) interpreted to be a chemical sediment. Kitayama et al. (2011) interpret the conglomeratic unit as a structural mélange of restricted local lithologies, in agreement with the fact that they seem to occur principally in high strain zones. This would suggest that the zircons in the conglomeratic unit do not place any age constraints on the age of the emplacement of the mafic units of the NGB. The similarity in isotopic compositions between the conglomeratic units and the quartz-rich rock interpreted by Cates et al. (2011) to be a detrital quartzite, and the fact that they both contain zircons of the same age is consistent with a similar process for their formation and a similar source for the quartz and the sulfide. Thus, we consider that the quartz-rich rocks do not put geochronological constraints on the age of emplacement of the Ujaraaluk unit. Moreover, all 3.8 Ga zircon bearing rocks are found to the south of the NGB within less than $100 \mathrm{~m}$ of the contact with the tonalite, often in highly deformed 


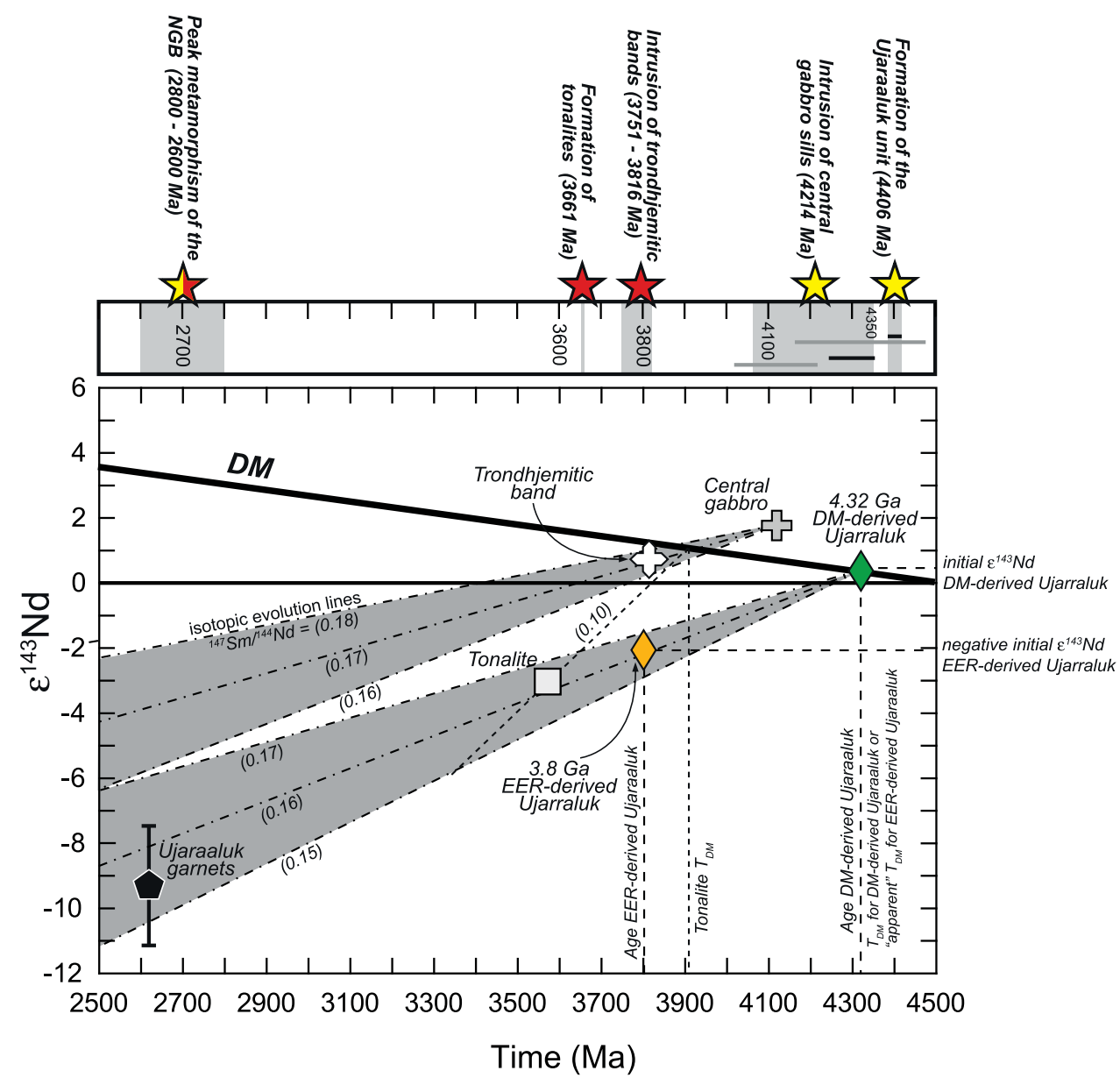

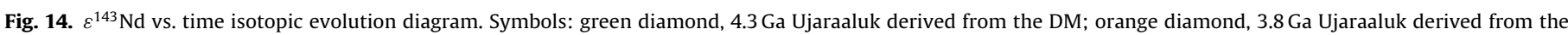

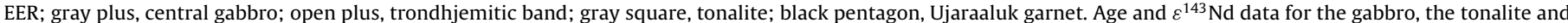

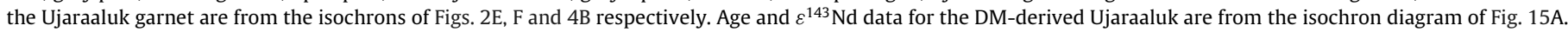

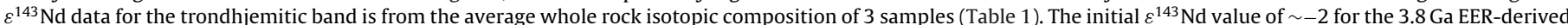

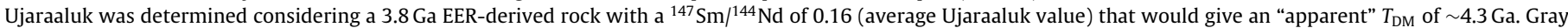

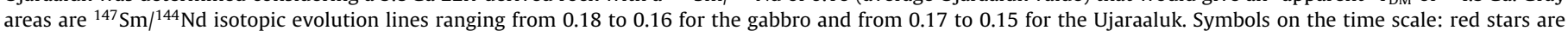

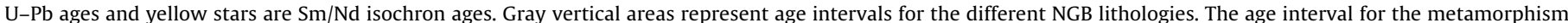

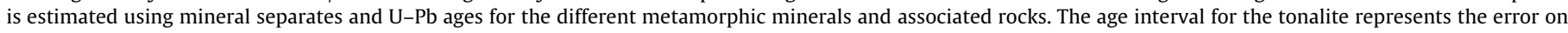

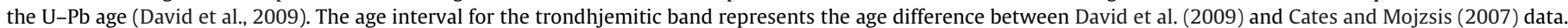

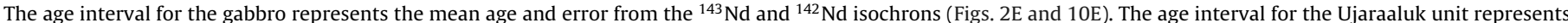

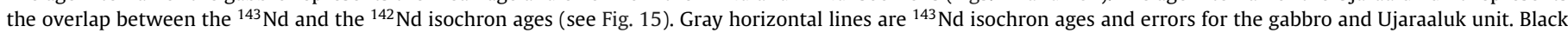

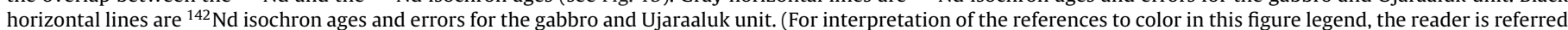
to the web version of the article.)

and sheared areas. The $3.8 \mathrm{Ga}$ zircons could therefore have been formed during an episode of intense deformation responsible for the formation of shearing and structural mélange zones consistent with the characteristics of the conglomeratic units. Although the $\sim 3800$ Ma intrusions of trondhjemetic bands place a minimum age on the Ujaraaluk unit, the Ujaraaluk also seems to contain rocks interpreted as metasediments that have 3630-3680 Ma zircon ages (Darling et al., 2012), suggesting deposition on a much older basement. This emphasizes the complex geologic history of the NGB and shows that ages obtained on rare zircon-bearing felsic rocks have to be interpreted with caution in terms of the constraints they provide on the age of the dominant mafic lithologies.

\subsection{Proposed time scale for the NGB}

In this section, we summarize all geochronological evidence to establish a time scale for the NGB and to constrain its secular evolution (Fig. 14). The minimum age of 3.75-3.82 Ga for the NGB was previously established from $\mathrm{U}-\mathrm{Pb}$ data on the zircons in the felsic trondhjemitic bands (Cates and Mojzsis, 2007; David et al., 2009). However, the NGB also is intruded by gabbro sills that yield ${ }^{143} \mathrm{Nd}$ and ${ }^{142} \mathrm{Nd}$ isochron ages at $\sim 4.2 \mathrm{Ga}$ which pushes back the minimum age of the belt into the Hadean. The Ujaraaluk unit is intruded by the central gabbros and therefore must be older than $\sim 4.2 \mathrm{Ga}$. The only model that adequately explains all aspects of the ${ }^{142} \mathrm{Nd}$ isotopic variation within the comagmatic Ujaraaluk and ultramafic sills is the one in which the Ujaraaluk unit formed while ${ }^{146} \mathrm{Sm}$ was still actively decaying. Therefore, the correlations between the $\mathrm{Sm} / \mathrm{Nd}$ and ${ }^{142} \mathrm{Nd} /{ }^{144} \mathrm{Nd}$ ratios for each of the Ujaraaluk compositional groups may represent isochrons dating the formation of the Ujaraaluk at $\sim 4.4 \mathrm{Ga}$. The Ujaraaluk unit is surrounded by the $3.66 \mathrm{Ga}$ Nuvvuagittuq tonalities that apparently formed by the partial melting of the Hadean mafic Ujaraaluk unit from which they inherit their ${ }^{142} \mathrm{Nd}$ deficit (Fig. 13). The initial $\varepsilon^{143} \mathrm{Nd}$ value indicated by the ${ }^{147} \mathrm{Sm}-{ }^{143} \mathrm{Nd}$ isochron for tonalites falls on the ${ }^{143} \mathrm{Nd}$ evolution line of the $\sim 4.4 \mathrm{Ga}$ Ujaraaluk unit (Fig. 14). The trondhjemitic bands also have a ${ }^{142} \mathrm{Nd}$ deficit and may as well have been formed by the partial melting of the Ujaraaluk unit. 

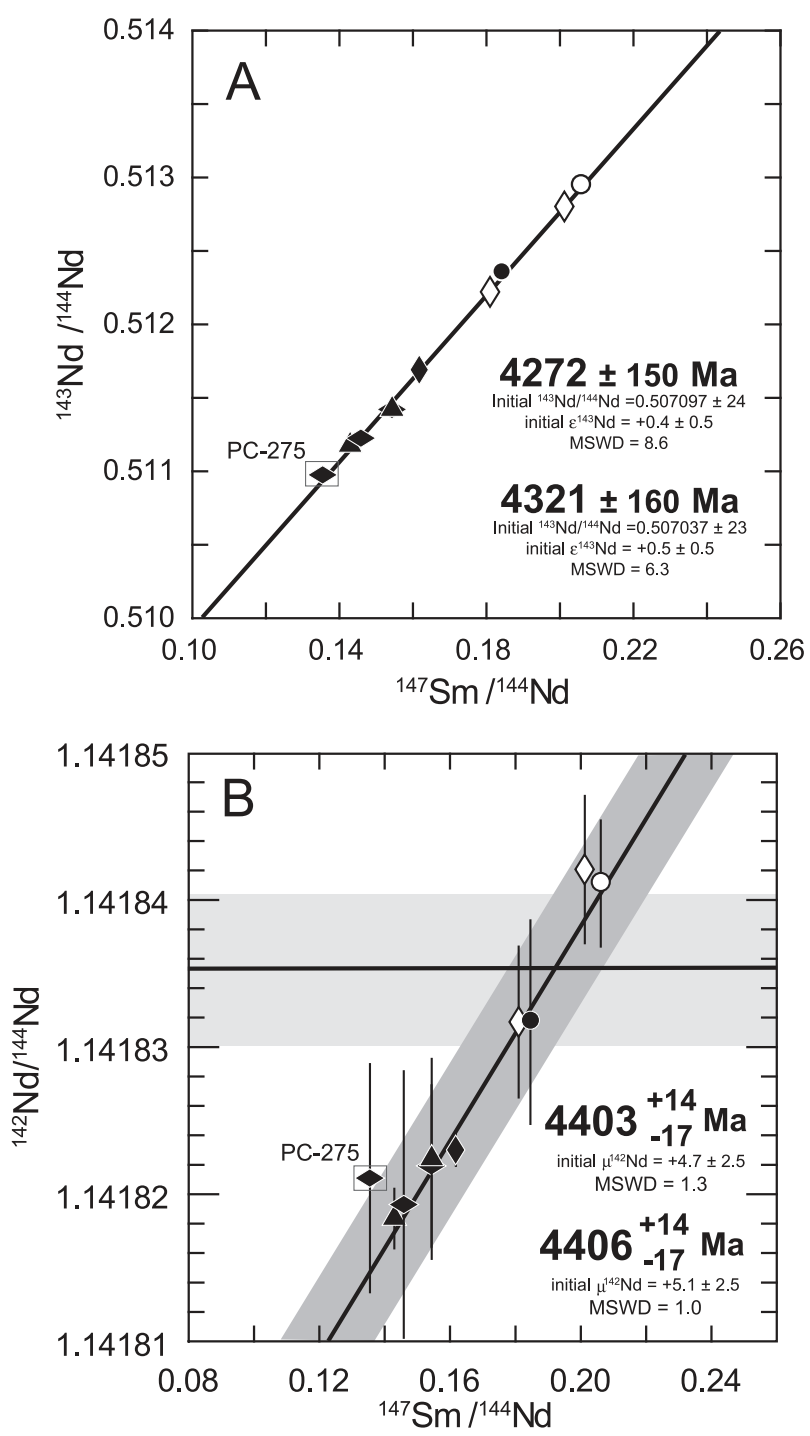

Fig. 15. (A) ${ }^{147} \mathrm{Sm} /{ }^{144} \mathrm{Nd}$ vs. ${ }^{143} \mathrm{Nd} /{ }^{144} \mathrm{Nd}$ isochron diagram and (B) ${ }^{147} \mathrm{Sm} /{ }^{144} \mathrm{Nd}$ vs. ${ }^{142} \mathrm{Nd} /{ }^{144} \mathrm{Nd}$ isochron diagram for the least disturbed Ujaraaluk samples and cogenetic ultramafic rocks. Gray bands show the $4.5 \mathrm{ppm}$ external error on the terrestrial standard value and the best fit line on the ${ }^{147} \mathrm{Sm} /{ }^{144} \mathrm{Nd}$ vs. ${ }^{142} \mathrm{Nd} /{ }^{144} \mathrm{Nd}$ isochron diagram.

However the average initial $\varepsilon^{143} \mathrm{Nd}$ value of the 3 trondhjemitic band samples $(+0.8)$ falls closer to the evolution line of the central gabbros suggesting that their source may instead be the $4.2 \mathrm{Ga}$ gabbros with $\mu^{142} \mathrm{Nd}$ values overlapping with the $\mu^{142} \mathrm{Nd}$ values for the trondhjemitic bands (Fig. 14). The NGB was then metamorphosed at $\sim 2.7 \mathrm{Ga}$ with the concomitant intrusion of pegmatite and the formation of metamorphic minerals such as garnets, rutiles, zircons and monazites. The isochron for garnet separates gives an initial $\varepsilon^{143} \mathrm{Nd}$ value falling on the ${ }^{143} \mathrm{Nd}$ evolution line of the $4.4 \mathrm{Ga}$ Ujaraaluk unit consistent with their crystallization from a parent rock that was an mafic Hadean rock before metamorphism (Fig. 14).

The $2.7 \mathrm{Ga}$ thermal event also affected the long-lived Sm-Nd isotopic system for some of the Ujaraaluk unit resulting in poorly defined isochrons ranging from $3.7 \mathrm{Ga}$ to $2.5 \mathrm{Ga}$ and a wide range in Sm-Nd model ages (Fig. 3A). A population of Ujaraaluk samples, however, has $T_{\mathrm{DM}}$ values near $4.3 \mathrm{Ga}$ (10 samples with $4.2 \mathrm{Ga} \leq T_{\mathrm{DM}} \leq 4.4 \mathrm{Ga}$; Fig. $3 \mathrm{~A}$ ). This cluster of samples with Hadean model ages could reflect one of three possibilities: (1) they are derived from a "normal" DM at $\sim 4.3 \mathrm{Ga}$ and have suffered little or no later modification of their Sm-Nd systems, (2) they were derived from an enriched (negative $\varepsilon^{143} \mathrm{Nd}$; EER in Fig. 14) source at $3.8 \mathrm{Ga}$ or later, or (3) their $\mathrm{Sm} / \mathrm{Nd}$ ratios have been metamorphically disturbed, resulting in erroneously old $T_{\mathrm{DM}}$ model ages. In case 1 , the ${ }^{147} \mathrm{Sm}-{ }^{143} \mathrm{Nd}$ isochron defined by these samples would yield an age of $4.3 \mathrm{Ga}$ with an initial $\varepsilon^{143} \mathrm{Nd}$ value of $\sim+0.5$. In both cases 2 and 3, the ${ }^{147} \mathrm{Sm}-{ }^{143} \mathrm{Nd}$ isochron for this group of samples would yield a younger $(2.5-3.8 \mathrm{Ga})$ age with a negative initial $\varepsilon$ Nd value (Fig. 14). Fig. 15 A shows a ${ }^{147} \mathrm{Sm}-{ }^{143} \mathrm{Nd}$ isochron for the sub-population of samples with $T_{\mathrm{DM}}$ values between $4.2 \mathrm{Ga}$ and $4.4 \mathrm{Ga}$. This isochron yields an age of $4272 \pm 150 \mathrm{Ma}$ with an initial $\varepsilon^{143} \mathrm{Nd}$ value of $+0.4 \pm 0.5$ consistent with derivation from a "normal" DM at $\sim 4.3 \mathrm{Ga}$ and not from an enriched missing source at $3.8 \mathrm{Ga}$. This suggests that this population of Ujaraaluk samples have the least disturbed ${ }^{147} \mathrm{Sm}-{ }^{143} \mathrm{Nd}$ systematics. The ${ }^{146} \mathrm{Sm}-{ }^{142} \mathrm{Nd}$ isochron plotting only these least disturbed samples gives an age of $4403^{+14}-17$ Ma (Fig. 15B), with very little scatter. As for the initial $\varepsilon^{143} \mathrm{Nd}$ value, the initial $\mu^{142} \mathrm{Nd}$ value of $+4.7 \pm 2.5$ for this isochron is consistent with derivation from the DM. Following the reasoning that post-4.0 Ga disturbance affects the $\mathrm{Sm} / \mathrm{Nd}$ ratio without affecting the ${ }^{142} \mathrm{Nd} /{ }^{144} \mathrm{Nd}$ ratio (i.e. a horizontal shift on the isochron diagram), samples falling further from the ${ }^{142} \mathrm{Nd}$ isochron have the most affected ${ }^{147} \mathrm{Sm} /{ }^{144} \mathrm{Nd}$ and thus the most affected ${ }^{143} \mathrm{Nd} /{ }^{144} \mathrm{Nd}$. In Fig. 15B, one of the least disturbed samples (PC-275) plots further from the isochron than the rest of the data, which we interpret as indicating that it has a slightly disturbed $\mathrm{Sm}-\mathrm{Nd}$ system. Taking this single sample off the isochrons of Fig. 15 , the ${ }^{143} \mathrm{Nd}$ age becomes $4321 \pm 160 \mathrm{Ma}\left(\mathrm{MSWD}=6.3\right.$ ), whereas the ${ }^{142} \mathrm{Nd}$ age becomes only 3 million years older (i.e. $4406^{+14}-17 \mathrm{Ma}$; MSWD $=1.0$ ). While this subset of samples admittedly has been highly screened in an effort to identify the most pristine samples, nevertheless, this set of samples has consistent Sm-Nd systematics for both the long-lived and short-lived systems both of which give overlapping Hadean ages. Thus, our best estimate for the age of the Ujaraaluk unit is $4406^{+14}{ }_{-17} \mathrm{Ma}$, which makes it the oldest vestige of crust preserved on Earth. The age of the Ujaraaluk unit overlaps those of the oldest Jack Hills zircons (Wilde et al., 2001) and the oldest zircons from the Moon (Nemchin et al., 2009), suggesting the intriguing possibility that the Nuvvuagittuq Greenstone Belt may preserve a remnant of the first crust formed on Earth after the giant impact that formed the Moon.

\section{Conclusions}

The ${ }^{142} \mathrm{Nd}$ data set for the Nuvvuagittuq Greenstone Belt rocks has been increased to more than 70 samples. The range in ${ }^{142} \mathrm{Nd} /{ }^{144} \mathrm{Nd}$ ratios is now $26 \mathrm{ppm}(-18 \mathrm{ppm}$ to $+8 \mathrm{ppm})$ and the expanded dataset for the Ujaraaluk rocks and associated ultramafic cumulates continues to show a good correlation between the $\mathrm{Sm} / \mathrm{Nd}$ and the ${ }^{142} \mathrm{Nd} /{ }^{144} \mathrm{Nd}$ ratios for each compositional group. Although a complex mixing model involving an early depleted reservoir and two never-seen-before early enriched reservoirs conceivably could explain this correlation, such a multiple source mixing model cannot account for several characteristics of the Nuvvuagittuq rocks. (1) The major and trace element compositions of the Ujaraaluk are not consistent with simple mixing between a single depleted and a single enriched reservoir. (2) All the compositionally distinct Ujaraaluk groups follow the exact same $\mathrm{Sm} / \mathrm{Nd}$ vs. ${ }^{142} \mathrm{Nd}$ correlation. The fact that the composition of these groups indicate their derivation from at least three sources with distinct geochemical features followed by distinct fractional crystallization histories under different conditions makes it unlikely that any simple mixing scenario would simultaneously produce identical $\mathrm{Sm} / \mathrm{Nd}$ vs. ${ }^{142} \mathrm{Nd} /{ }^{144} \mathrm{Nd}$ correlations in all three groups. (3) In a mixing scenario, a correlation between the ${ }^{142} \mathrm{Nd}$ and ${ }^{143} \mathrm{Nd}$ isotopic compositions with $\mathrm{Nd}$ concentration would be expected at the time the mixing occurred, as would "fossil" ${ }^{147} \mathrm{Sm}-{ }^{143} \mathrm{Nd}$ 
correlations giving ages older than the presumed mixing event. None of these features are present in the Ujaraaluk isotopic data. (4) A mixing event or a melt-restite relationship in the Eoarchean cannot explain the $\mathrm{Sm} / \mathrm{Nd}$ vs. ${ }^{142} \mathrm{Nd}$ correlation observed between the mafic Ujaraaluk and their cogenetic ultramafic cumulates. (5) An Eoarchean formation age for the Ujaraaluk cannot be reconciled with the intruding gabbros yielding ${ }^{142} \mathrm{Nd}$ and ${ }^{143} \mathrm{Nd}$ isochrons with Hadean ages.

All these features, however, can be explained by a simple model where the $\mathrm{Sm} / \mathrm{Nd}$ vs. ${ }^{142} \mathrm{Nd}$ correlation is produced by igneous fractionation of the $\mathrm{Sm} / \mathrm{Nd}$ ratio at constant $\mathrm{Nd}$ isotopic composition at a time when ${ }^{146} \mathrm{Sm}$ was still actively decaying, leading to ${ }^{142} \mathrm{Nd}$ isochron ages of $\sim 4.4 \mathrm{Ga}$. The least disturbed Ujaraaluk samples yield a ${ }^{142} \mathrm{Nd}$ isochron age of $4406^{+14}{ }_{-17}$ Ma and a ${ }^{143} \mathrm{Nd}$ isochron age of $4321 \pm 160 \mathrm{Ma}$ supporting an Hadean age. Intruding gabbros give overlapping ${ }^{143} \mathrm{Nd}$ and ${ }^{142} \mathrm{Nd}$ isochron ages with a mean of $4214 \pm 140$ Ma providing additional support for an Hadean age for the NGB. Therefore, the ${ }^{147} \mathrm{Sm}-{ }^{143} \mathrm{Nd}$ and ${ }^{146} \mathrm{Sm}-{ }^{142} \mathrm{Nd}$ isotopic compositions in the mafic lithologies of the Nuvvuagittuq Greenstone Belt suggest that it represents the oldest crustal remnant on Earth. Following Hadean formation, the NGB was subjected to a complex structural and metamorphic reworking recording over a billion years of Earth's Archean history. Despite the fact that this metamorphic history has affected the long-lived ${ }^{147} \mathrm{Sm}-{ }^{144} \mathrm{Nd}$ isotopic system, the short-lived ${ }^{146} \mathrm{Sm}-{ }^{142} \mathrm{Nd}$ system has not been significantly affected. lows:

The geological evolution of the NGB can be summarized as fol-

(1) 4.3-4.4Ga: Eruption and crystallization of the Ujaraaluk unit and comagmatic ultramafic sills. The Ujaraaluk unit exhibits a transition from basaltic rocks having tholeitic affinities to basaltic rocks that resemble modern boninites to basaltic/andesitic rocks having calk-alkaline affinities.

(2) $4.2 \mathrm{Ga}$ : Intrusion of gabbro sills in the central part of the NGB.

(3) $3.8 \mathrm{Ga}$ : Intrusion of trondhjemitic bands produced by the melting of the mafic lithologies. Possible development of shear zones and sutures composed of recrystallized quartz that locally resembles conglomerate texture.

(4) 3.66 Ga: Formation of the surrounding NGB tonalites by partial melting of the Hadean mafic lithologies.

(5) 3.3 Ga: Possible metamorphic event recorded in a small population of zircons (David et al., 2009).

(6) $\sim 2.7 \mathrm{Ga}$ : Extensive metamorphism concomitant with the intrusion of pegmatites, formation of metamorphic minerals including garnet, rutile, monazite and zircon in the Ujaraaluk unit, orthopyroxene in the ultramafic sills and zircons in the gabbro sills.

Despite the fact that the Nuvvuagittuq Greenstone Belt was formed less than 300 million years after the beginning of Earth's accretion, it shares geochemical affinities with numerous younger Archean greenstone belts. This suggests that the geological processes still responsible for forming crust were established very early in the Earth's history. Nevertheless, evidence for the existence of stable crust shortly after the Moon forming impact is becoming more abundant, with the 4.3-4.4 Ga Nuvvuagittuq Ujaraaluk and the $4.4 \mathrm{Ga}$ Jack Hills zircons being contemporaneous with the formation of the lunar crust at 4.36-4.41 Ga (Borg et al., 2011; Nemchin et al., 2009).

\section{Acknowledgements}

We are grateful to the people and municipality of Inukjuak for their hospitality. We would like to thank the people of the
Pituvik Landholding Corporation, especially Mike Carroll, Johnny Mina, Minnie Palliser, Simeonie Elyasiapik, Arthur Elyasiapik, Aliva Epoo, Simeonie, Minnie Nowkawalk and Noah Echalook, for their critical logistical support in the field. We acknowledge Mary Horan and Timothy Mock for assistance and support in the chemistry lab and with the mass-spectrometers. We also thank Jean-Luc Devidal for assistance on the Microprobe. We acknowledge Mohadeseh Majnoon and Bill Minarik for providing the pegmatite sample. The present paper greatly benefited from useful scientific discussions with Hanika Rizo, Maud Boyet and Steve Shirey. We also thank Alan Brandon and the editor Peter Cawood for their useful comments on the manuscript. This work was supported by the National Science and Engineering Research Council of Canada [Discovery Grants RGPIN 7977-00 to D.F.], the National Science Foundation [NSF-EAR0910442 to R.W.C.] and the Carnegie Canada Foundation.

\section{References}

Adam, J., Rushmer, T., O’Neil, J., Francis, D., 2011. Hadean greenstones and the origin of the Earth's early continental crust. Prague Goldschmidt conference abstract. Mineralogical Magazine 75, 407.

Bennett, V.C., Brandon, A.D., Nutman, A.P., 2007. Coupled ${ }^{142} \mathrm{Nd}-{ }^{143} \mathrm{Nd}$ isotopic evidence for Hadean mantle dynamics. Science 318, 1907-1910.

Blichert-Toft, J., Albarede, F., 2008. Hafnium isotopes in Jack Hills zircons and the formation of the Hadean crust. Earth and Planetary Science Letters 265, 686-702.

Boily, M., Leclair, A., Maurice, C., Bédard, J.H., David, J., 2009. Paleo- to Mesoarchean basement recycling and terrane definition in the Northeastern Superior Province, Québec, Canada. Precambrian Research 168, 23-44.

Borg, L.E., Connelly, J.N., Boyet, M., Carlson, R.W., 2011. Chronological evidence that the Moon is either young or did not have a global magma ocean. Nature 477 , 70-72.

Bouvier, A., Vervoort, J.D., Patchett, J.P., 2008. The Lu-Hf and Sm-Nd isotopic composition of CHUR: constraints from unequilibrated chondrites and implications for the bulk composition of terrestrial planets. Earth and Planetary Science Letters 273, 48-57.

Bowring, S.A., Williams, I.S., 1999. Priscoan (4.00-4.03 Ga) orthogneisses from northwestern Canada. Contributions to Mineralogy and Petrology 134, 3-16.

Boyet, M., Carlson, R.W., 2005. ${ }^{142} \mathrm{Nd}$ evidence for early (>4.53 Ga) global differentiation of the silicate Earth. Science 309, 576-581.

Boyet, M., Carlson, R.W., 2006. A new geochemical model for the Earth's mantle inferred from ${ }^{146} \mathrm{Sm}-{ }^{142} \mathrm{Nd}$ systematics. Earth and Planetary Science Letters 250 254-268.

Boyet, M., Carlson, R.W., 2007. A highly depleted moon or a non-magma ocean origin for the lunar crust? Earth and Planetary Science Letters 262, 505-516.

Carlson, R.W., Boyet, M., Horan, M., 2007. Chondrite barium, neodymium, and samarium isotopic heterogeneity and early Earth differentiation. Science 316, 1175-1178.

Carlson, R.W., Boyet, M., 2008. Composition of the Earth's interior: the importance of early events. Phil. Trans. R. Soc. 366, 4077-4103.

Carlson, R.W., Czamanske, G., Fedorenko, V., Ilupin, I., 2006. A comparison of Siberian meimechites and kimberlites; implications for the source of high-Mg alkalic magmas and flood basalts. Geochemistry, Geophysics, Geosystems $-G^{3} 7,1-21$.

Caro, G., Bourdon, B., Birck, J., Moorbath, S., 2003. ${ }^{146} \mathrm{Sm}-{ }^{142} \mathrm{Nd}$ evidence from Isua metamorphosed sediments for early differentiation of the Earth's mantle. Nature 423, 428-432.

Caro, G., Bourdon, B., Birck, J., Moorbath, S., 2006. ${ }^{142} \mathrm{Nd} /{ }^{144} \mathrm{Nd}$ measurements in terrestrial rocks; constraints on the early differentiation of the Earth's mantle. Geochimica et Cosmochimica Acta 70, 164-191.

Cates, N.L., Mojzsis, S.J., 2007. Pre-3750 Ma supracrustal rocks from the Nuvvuagittuq supracrustal belt, northern Quebec. Earth and Planetary Science Letters 255, $9-21$.

Cates, N.L., Mojzsis, S.J., 2009. Metamorphic zircon, trace elements and Neoarchean metamorphism in the ca. $3.75 \mathrm{Ga}$ Nuvvuagittuq supracrustal belt, Quebec (Canada). Chemical Geology 261, 98-113.

Cates, N.L., Mojzsis, S.J., Ziegler, K., Schmitt, A.K., 2011. Reworked Hadean crust in the ca. 3780 Ma Nuvvuagittuq supracrustal belt. Prague Goldschmidt conference abstract. Mineralogical Magazine 75, 633.

Collerson, K.D., 1983. Ion microprobe zircon geochronology of the Uivak gneisses: implications for the evolution of early terrestrial crust in the North Atlantic Craton. Lunar and Planetary Institute Technical Report 83, 28-33. 
Darling, J., Moser, D., Heaman, L., Davis, W., Stern, R., O’Neil, J., Carlson, R.W., Francis, D., 2012. Zircon U-Pb Geochronology of the Nuvvuagittuq Greenstone Belt. Montreal, Goldschmidt conference abstract.

David, J., Godin, L., Stevenson, R., O'Neil, J., Francis, D., 2009. U-Pb ages (3.8-2.7 Ga) and $\mathrm{Nd}$ isotope data from the newly identified Eoarchean Nuvvuagittuq supracrustal belt, Superior Craton, Canada. Geological Society of America Bulletin 121, 150-163.

Fletcher, I.R., Rosman, K.J.R., 1982. Precise determination of initial $\varepsilon$ Nd from Sm-Nd isochron data. Geochimica et Cosmochimica Acta 46, 1983-1987.

Jackson, S.E., Pearson, N.J., Griffin, W.L., Belousova, E.A., 2004. The application of laser ablation-inductively coupled plasma-mass spectrometry to in situ U-Pb zircon geochronology. Chemical Geology 211, 47-69.

Kemp, A.I.S., Wilde, S.A., Hawkesworth, C.J., Coath, C.D., Nemchin, A., Pidgeon, R.T., Vervoort, J.D., DuFrane, S.A., 2010. Hadean crustal evolution revisited; new constraints from $\mathrm{Pb}-\mathrm{Hf}$ isotope systematics of the Jack Hills zircons. Earth and Planetary Science Letters 296, 45-56.

Kinoshita, N., Paul, M., Kashiv, Y., Collon, P., Deibel, C.M., DiGiovine, B., Greene, J.P., Henderson, D.J., Jiang, C.L., Marley, S.T., Nakanishi, T., Pardo, R.C., Rehm, K.E., Robertson, D., Scott, R., Schmitt, C., Tang, X.D., Vondrasek, R., Yokoyama, A., 2012. A shorter ${ }^{146} \mathrm{Sm}$ half-life measured and implications for ${ }^{146} \mathrm{Sm}-{ }^{142} \mathrm{Nd}$ chronology in the solar system. Science 335, 1614-1617.

Kitayama, Y., Thomassot, E., O'Neil, J., Francis, D., Wing, B., 2011. Origins of apparent conglomerates of the Nuvvuagittuq Greenstone Belt (Nunavik, Québec): sulfur and oxygen isotope evidence and chronological implications. In: Abstract U13A0030 Presented at 2011 Fall Meeting, AGU, San Francisco, CA, 5-9 December.

Liu, D., Wilde, S.A., Wan, Y., Wu, J., Zhou, H., Dong, C., Yin, X., 2008. New U-Pb and $\mathrm{Hf}$ isotopic data confirm Anshan as the oldest preserved segment of the North China Craton. American Journal of Science 308, 200-231.

Ludwig, K.R., 2001. User's Manual for Isoplot/Ex Version 2.49, A Geochronological Toolkit for Microsoft Excel. Berkeley Geochronological Center, Special Publication 1a, Berkeley, USA, 55 pp.

Lugmair, G.W., Carlson, R.W., 1978. The Sm-Nd history of KREEP. In: Merrill, R.B. (Ed.), The Moon and Meteorites. Proceedings of the Lunar and Planetary Science Conference, vol. 1. , pp. 689-704.

Nemchin, A., Timms, N., Pidgeon, R., Geisler, T., Reddy, S., Meyer, C., 2009. Timing of crystallization of the lunar magma ocean constrained by the oldest zircon. Nature Geoscience 2,133-136.

Nutman, A.P., Friend, C.R.L., 2009. New 1:20,000 scale geological maps, synthesis and history of investigation of the Isua supracrustal belt and adjacent orthogneisses, southern West Greenland; a glimpse of Eoarchaean crust formation and orogeny. Precambrian Research 172, 189-211.

Nutman, A.P., McGregor, V.R., Friend, C.R.L., Bennett, V.C., Kinny, P.D., 1996. The Itsaq gneiss complex of southern West Greenland; the world's most extensive record of early crustal evolution (3900-3600 Ma). Precambrian Research 78, 1-39.

Nutman, A.P., Wan, Y., Liu, D., 2009. Zircon U/Pb and Hf isotopic constraints on the early Archean evolution in Anshan of the North China Craton; discussion. Precambrian Research 172, 357-360.

O'Neil, J., Carlson, R.W., Francis, D., Stevenson, R.K., 2008. Neodymium-142 evidence for Hadean Mafic Crust. Science 321, 1828-1831.

O'Neil, J., Francis, D., Carlson, R.W., 2011a. Implications of the Nuvvuagittuq Greenstone Belt for the formation of Earth's early crust. Journal of Petrology 52, 985-1009.
O'Neil, J., Carlson, R.W., Moser, D.E., Heaman, L.M., Francis, D., 2011b. Age and origin of the Nuvvuagittuq Greenstone Belt. Prague Goldschmidt conference abstract. Mineralogical Magazine 75, 1556.

O'Neil, J., Maurice, C., Stevenson, R.K., Larocque, J., Cloquet, C., David, J., Francis, D., 2007. The Geology of the $3.8 \mathrm{Ga}$ Nuvvuagittuk (Porpoise Cove) Greenstone Belt, northern Superior Province, Canada. In: Kranendonk, M.J., Smithies, R.H., Bennett, V.C. (Eds.), Earth's Oldest Rocks. Elsevier BV, Amsterdam, pp. 219-250.

Paquette, J.L., Tiepolo, M., 2007. High resolution (5 $\mu \mathrm{m}) \mathrm{U}-\mathrm{Th}-\mathrm{Pb}$ isotopes dating of monazite with excimer laser ablation (ELA)-ICPMS. Chemical Geology 240 222-237.

Pollington, A.D., Baxter, E.F., 2010. High resolution Sm-Nd garnet geochronology reveals the uneven pace of tectonometamorphic processes. Earth and Planetary Science Letters 293, 63-71.

Rankenburg, K., Brandon, A.D., Neal, C.R., 2006. Neodymium isotope evidence for chondritic composition of the Moon. Science 312, 1369-1372.

Rizo, H., Boyet, M., Blichert-Toft, J., Rosing, M., 2011. Combined Nd and Hf isotope evidence for deep-seated source of Isua lavas. Earth and Planetary Science Letters $312,267-279$.

Roth, A.S.G., Bourdon, B., Kleine, T., Mojzsis, S.J., Touboul, M., 2011. Inherited ${ }^{142} \mathrm{Nd}$ anomalies in the Nuvvuagittuq supracrustal belt. Prague Goldschmidt conference abstract. Mineralogical Magazine 75, 1759.

Schiotte, L., Compston, W., Bridgwater, D., 1989. Ion probe U-Th-Pb zircon dating of polymetamorphic orthogneisses from northern Labrador, Canada. Canadian Journal of Earth Sciences 26, 1533-1556.

Simard, M., Parent, M., David, J., Sharma, K.N.M., 2003. Géologie de la région de la rivière Innuksuac (34K et 34L). Ministère des Ressources naturelles, Québec, RG 2002-10, 46 pp.

Simon, L., Nigel, M.K., 2007. Ancient Antarctica: the Archean of the east Antarctic Shield. In: Kranendonk, M.J., Smithies, R.H., Bennett, V.C. (Eds.), Earth's Oldes Rocks. Elsevier BV, Amsterdam, pp. 149-186.

Song, B., Nutman, A.P., Liu, D., Wu, J., 1996. 3800 to 2500 Ma crustal evolution in the Anshan area of Liaoning Province, northeastern China. Precambrian Research 78, 79-94.

Sun, S.S., McDonough, W.F., 1989. Chemical and isotopic systematics of oceanic basalts; implications for mantle composition and processes. In: Saunders, A.D. Norry, M.J. (Eds.), Magmatism in the Ocean Basins. London, Geological Society of London, pp. 313-345.

Tiepolo, M., 2003. In situ Pb geochronology of zircon with laser ablation-inductively coupled plasma-sector field mass spectrometry. Chemical Geology 141, 1-19.

Wilde, S.A., Valley, J.W., Peck, W.H., Graham, C.M., 2001. Evidence from detrital zircons for the existence of continental crust and oceans on the Earth $4.4 \mathrm{Gyr}$ ago. Nature 409, 175-178.

Williams, I.S., Black, L.P., Compston, W., 1986. Four zircon ages from one rock: the evolution of a 3930 Ma-old granulite from Mount Sones, Antarctica. Terra Cog nita 6,153 .

Wu, F., Zhang, Y., Yang, J., Xie, L., Yang, Y., 2008. Zircon U/Pb and Hf isotopic constraints on the early Archean crustal evolution in Anshan of the North China Craton. Precambrian Research 167, 339-362.

Wu, F., Zhang, Y., Yang, J., Xie, L., Yang, Y., 2009. Zircon U/Pb and Hf isotopic constraints on the early Archean crustal evolution in Anshan of the North China Craton; reply. Precambrian Research 172, 361-363. 